LA HISTORIA DE DON ÁNGEL

EDGAR FELIPE MILLÁN PRADA

MAESTRÍA EN DEFENSA DE LOS DERECHOS HUMANOS Y DEL DERECHO INTERNACIONAL HUMANITARIO ANTE ORGANISMOS, CORTES Y TRIBUNALES INTERNACIONALES

UNIVERSIDAD SANTO TOMÁS BOGOTÁ D.C.

2019 


\section{LA HISTORIA DE DON ÁNGEL}

MONOGRAFÍA PRESENTADA PARA OBTENER EL TÍTULO DE MAGISTER EN DEFENSA DE LOS DERECHOS HUMANOS Y DEL DERECHO INTERNACIONAL HUMANITARIO ANTE ORGANISMOS, CORTES Y TRIBUNALES INTERNACIONALES

LINA MARÍA MEJÍA TORRES DIRECTORA

EDGAR FELIPE MILLÁN PRADA

UNIVERSIDAD SANTO TOMÁS, BOGOTÁ D.C. 


\section{Agradecimientos}

A Don Ángel, el protagonista de esta historia, quien decidió contar su pasado sin temor a revivir aquellas heridas que le produjo el conflicto armado colombiano. Fueron más sus ganas de dar a conocer su historia para así luchar contra la impunidad de su caso.

También un agradecimiento al Doctor Alejandro Valencia Villa, quien lideró en un comienzo la línea de investigación.

Un agradecimiento muy especial a la Directora de la Línea de Investigación en Crímenes Internacionales, la Doctora Lina María Mejía Torres gracias a sus consejos, dedicación, paciencia y compromiso pude realizar esta investigación, para ella mi más sincero agradecimiento, admiración y respeto.

Por último pero no menos importante agradezco a Dios y a mi familia por todo el apoyo. 
Tabla de Contenido

Pág.

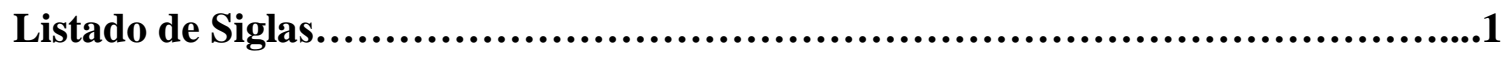

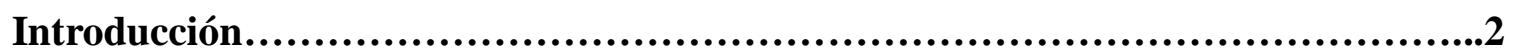

\section{CAPÍTULO I}

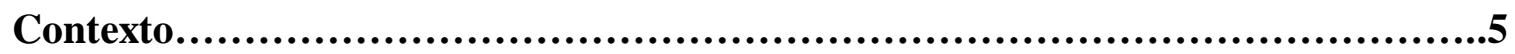

\section{CAPÍTULO II}

Hechos................................................................................

\section{CAPÍTULO III}

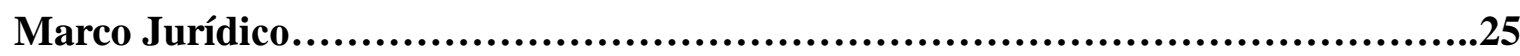

\section{CAPÍTULO IV}

Acceso a la Justicia..............................................................60

\section{CAPítulo V}

Impactos..............................................................................67

\section{CAPítulo VI}

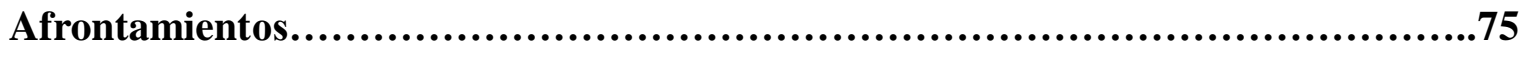

\section{CAPÍTULO VII}

Medidas de Reparación..............................................................80

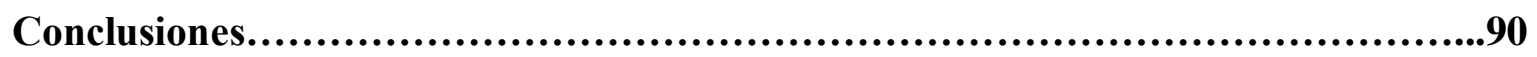

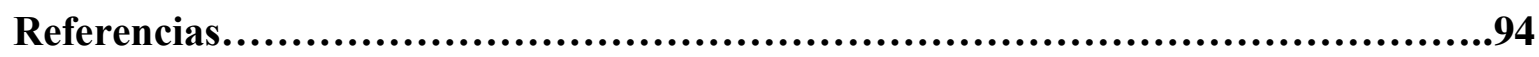

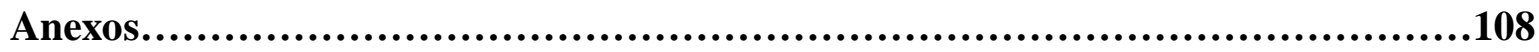




\section{LISTA DE GRÁFICOS}

Gráfico 1. Comunas de Buenaventura.........................................6

Gráfico 2. Diagnóstico Ambiental............................................

Gráfico 3. Tasa de Homicidios............................................. 11

Gráfico 4. Bloque Calima....................................................13

Gráfico 5. Masacres......................................................... 15

Gráfico 6. Línea de Tiempo..................................................24

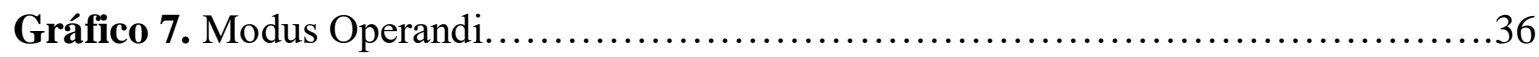

Gráfico 8. Desplazamiento ...............................................41

Gráfico 9. Estándares Internacionales........................................59

Gráfico 10. Perspectiva Psicosocial...........................................74 


\section{LISTA DE ANEXOS}

\section{ANEXO A. CONSENTIMIENTO}

Anexo 1. Consentimiento informado del señor Luis Ángel Sinisterra Viveros.

Anexo 1.

\section{ANEXO B. ENTREVISTAS}

Entrevista. Señor Luis Ángel Sinisterra Viveros. Realizada el 28 de marzo de 2017.

\section{Anexo 2.}

Entrevista. Señor Luis Ángel Sinisterra Viveros. Realizada el 28 de agosto de 2018.

\section{Anexo 3.}

Entrevista. Señor Luis Ángel Sinisterra Viveros. Realizada el 28 de diciembre de 2018.

\section{Anexo 4.}

Entrevista .Señor Juan*. Realizada el 14 de noviembre de 2018.

\section{ANEXO C. AUDIOS}

\section{Anexo 1.}

Audio. Señor Ángel, 28 de marzo de 2017.

Anexo 2.

Audio. Señor Ángel, 28 de agosto de 2018.

\section{Anexo 3.}

Audio. Señor Ángel, 28 de diciembre de 2018.

\section{Anexo 4.}

Audio. Señor Juan*, 14 de noviembre de 2018. 


\section{LISTADO DE SIGLAS}

DDHH. Derechos Humanos

DIDH. Derecho Internacional de los Derechos Humanos

DIH Derecho Internacional Humanitario

DFI Desplazamiento Forzado Interno ONU Organización de las Naciones Unidas

CIDH. ..Comisión Interamericana de Derechos Humanos

CIDH. Corte Interamericana de Derechos Humanos

ONG. .Organización No Gubernamental

HRW .Human Rights Watch ASFROVICTOL Asociación Afro Víctima del Conflicto del Tolima FAC .Fuerzas Armadas de Colombia

FARC Fuerzas Armas Revolucionarias de Colombia CMMC Columna Móvil Manuel Cepeda ELN Ejército de Liberación Nacional AUC Autodefensas Unidas de Colombia AGC Autodefensas Gaitanistas de Colombia

BACRIM Bandas Criminales

GPDP Grupo Pos Desmovilización Paramilitar H.H. Helbert Veloza $\mathrm{ACCU}$ . Autodefensas Campesinas de Córdoba y Urabá

CERAC Centro de Recursos para el Análisis de Conflictos CNMH. Centro Nacional De Memoria Histórica CNRR .Comisión Nacional de Reparación y Reconciliación CINEP. .Centro de Investigación y Educación Popular DINAC Dirección Nacional de Contextos de la Fiscalía Nacional $\mathrm{CNDH}$ ..Comisión Nacional de Derechos Humanos URT. .Unidad de Restitución de Tierras 


\section{Introducción}

La línea de investigación en crímenes internacionales comprende un análisis de reconstrucción de casos de violaciones de derechos humanos e infracciones al derecho internacional humanitario bajo el contexto del conflicto armado colombiano con una metodología similar a la empleada en una comisión de la verdad.

Las comisiones de la verdad en América Latina son organismos creados para ayudar a las sociedades que han sufrido masivas violaciones de derechos humanos producidas por la violencia o por las guerras. En Colombia con el fin del conflicto con las FARC, la sociedad colombiana y principalmente las víctimas reclaman que se esclarezca y se conozca la verdad sobre lo ocurrido en el conflicto. Con el fin superar las profundas crisis en la sociedad y evitar que estos hechos se repitan en el futuro. ${ }^{1}$

En cuanto a la metodología de las comisiones de la verdad es centrada en la investigación de las violaciones de derechos humanos con un componente jurídico o histórico y también psicosocial con testimonios de las víctimas. Como por ejemplo en comisiones de la verdad de Perú, Brasil y Argentina los testimonios de los testimonios de los sobrevivientes de los conflictos, familiares de las víctimas y los testigos son recursos de gran valor e importancia para obtener la verdad. ${ }^{2}$

En el Proyecto Ruta Pacífica De Las Mujeres, la metodología centrada en la investigación de las violaciones de derechos humanos bajo el marco del conflicto armado colombiano tiene un componente jurídico y psicosocial con un enfoque feminista. La principal característica es el enfoque feminista, el cual se realizó por la carencia y limitaciones que tienen las comisiones de la verdad sobre el enfoque de género. ${ }^{3}$

En este marco, la víctima contó su historia de los hechos por los cuales luego de realizar un exhaustivo estudio y análisis jurídico, se logró determinar la calidad de víctima de violaciones de derechos humanos e infracciones al derecho internacional humanitario y determinar cómo estas conductas reunieron los elementos que constituyen crímenes internacionales a la luz de los mecanismos internacionales de defensa de derechos humanos.

La presente línea de investigación tiene una estructura de siete ejes: Contexto, Hechos, Marco Jurídico (Nacional e Internacional), Crimen Internacional, Acceso a la Justicia,

\footnotetext{
${ }^{1}$ Oficina del Alto Comisionado para la Paz. (s.f) ABC Medidas de Reparación Integral para la Construcción de Paz. Recuperado de http://www.altocomisionadoparalapaz.gov.co/Documents/informes-especiales/abc-del-proceso-de-paz/abc-medidas-reparacion-integralpara-construccion-paz.html

${ }^{2}$ Cuya, E. (s.f). Las Comisiones de la Verdad en América Latina. Recuperado de http://www.derechos.org/koaga/iii/1/cuya.html

${ }^{3}$ Alfonso Carla y Martín Beristain. (2013). Ruta Pacífica de las Mujeres. Bilbao, España: Universidad del País Vasco y Hegoa.
} 
Impactos, Afrontamientos y Demandas de Reparación (Medidas de Indemnización, Restitución, Rehabilitación, Medidas de Satisfacción y Garantías de No Repetición).

El estudiante candidato a la maestría logró ubicar a una víctima del conflicto armado, quien accedió a contar su historia y se le informó que sería usada su información para fines estrictamente académicos, para garantizar este acuerdo se realizó un consentimiento firmado por las partes.

La línea de investigación se ajusta a la metodología sociojurídica, porque se utilizó el trabajo de campo para conocer unos hechos narrados directamente por la víctima de violaciones de derechos humanos e infracciones al derecho internacional humanitario, en un contexto de conflicto armado interno colombiano principalmente en la ciudad de Buenaventura, Valle del Cauca e Ibagué, Tolima. Implicó de esta manera un contacto directo con la víctima para determinar mediante un análisis jurídico si los hechos constituyen un crimen internacional. Se emplearon varios tipos de fuentes como cerradas y abiertas, primarias y secundarias, con las cuales se pudo argumentar, nutrir y documentar hechos relevantes en el proceso investigativo como lo son mapas que plasman los hechos de violencia en Buenaventura Valle del Cauca, la historia del conflicto armado en el principal puerto de Colombia en el pacífico, características sobre los grupos armados que operan en la zona y demás datos relevantes para llevar a cabo la línea de investigación.

Este tipo de metodología sociojurídica es fundamental el contacto directo con la víctima. Por ende se trabajó mediante entrevistas para conocer de voz directa de la víctima los hechos, las experiencias, impactos y afrontamientos. Además se logró entrevistar a un amigo de la infancia de la víctima con el fin de conocer desde otra perspectiva los hechos narrados.

La investigación en crímenes internacionales, busca determinar si los hechos de violaciones de derechos humanos e infracciones al derecho internacional humanitario que padeció la víctima bajo el contexto del conflicto armado interno colombiano se constituyen como crímenes internacionales basado en un análisis jurídico de los elementos que configuran estas conductas como crímenes internacionales. También, busca concientizar sobre las dificultades y padecimientos que afronta una víctima del conflicto armado colombiano. Por esta razón, la importancia de dar a conocer una historia de una víctima sobreviviente al conflicto armado padecido en el municipio de Buenaventura Valle del Cauca, que presenta un contexto histórico de violencia.

El relato de la víctima es esencial para llevar a cabo la investigación debido a que como se mencionó la metodología de la línea de investigación en crímenes internacionales, es similar a una comisión de la verdad, por lo tanto el relato de los hechos de la víctima es trascendental para el desarrollo de la línea de investigación.

Entre las fuentes usadas para la metodología se utilizó el informe del Centro Nacional de Memoria Histórica, Buenaventura: Un Puerto Sin Comunidad (2015). En donde se recopilan por ejemplo, el contexto sobre el conflicto armado interno en el puerto del 
pacífico colombiano, sus antecedentes e historia, datos estadísticas sobre las violaciones de derechos humanos tales como las masacres registradas en la zona, las declaraciones de ex comandantes paramilitares sobre la situación del conflicto armado en Buenaventura, mapeos y datos claves para llevar a cabo la investigación.

La línea de investigación es pertinente porque es además un espacio para conocer la historia de una víctima del conflicto armado interno colombiano que desea que su historia no quede en la impunidad, y además sirva para contribuir al reconocimiento de las víctimas del conflicto armado interno de Colombia y pueda ser utilizada como garantía de no repetición. 


\section{CAPÍTULO I}

\section{CONTEXTO}

\section{Antecedentes Históricos}

El municipio de Buenaventura Valle del Cauca, fue fundado el 14 de julio de 1540, por Juan de Ladrilleros, en cumplimiento de una orden del adelantado Pascual de Andagoya, venido al continente con Vasco Núñez de Balboa. Gärtner (2005) y Aprile-Gniset (2002) citado por Pérez (2007, p.4), menciona que los conquistadores españoles no tuvieron la intención de poblar y construir un asentamiento en lo que hoy es Buenaventura, porque la resistencia de los nativos, el clima demasiado cálido y una selva espesa que sumados eran muy hostiles como para crear un centro de operaciones allí.

En cuanto a la toponimia de este municipio, le fue concebido por el día de la fiesta de San Buenaventura $^{4}$ y por la tranquilidad de la bahía. (Gobernación del Valle del Cauca, 2006, p.1).

Solo hasta el siglo XIX las autoridades de Cali vieron la importancia económica que produce el puerto de Buenaventura y crearon un camino que comunica a Cali con Buenaventura. Este camino antiguo se logró luego de oposiciones de terceros que se beneficiaban utilizando indígenas, nativos y comerciantes para llevar sus encomiendas bajo las difíciles condiciones geográficas de la zona.

A finales del siglo XIX iniciaron una serie de hechos desafortunados para Buenaventura, el gobierno nacional otorgó tierras y casas bajo la misión de poblar el puerto y fomentar su economía, pese a que llegaron extranjeros para invertir en la economía portuaria lastimosamente llegaron desastres naturales consigo, como un terremoto y un incendio, además arribaron enfermedades como la fiebre amarilla y la viruela que acabaron con gran parte de la población. Pese a los infortunios, la población de Buenaventura continuó trabajando por el puerto, como lo menciona Pérez (2007, p.6), "Pese a todos estos acontecimientos la población estaba empeñada no sólo en quedarse sino en convertir a Buenaventura en un sitio mejor".

\section{Ubicación Geográfica}

El municipio está situado en el departamento del Valle del Cauca, en la subregión occidental. A $121 \mathrm{~km}$ de Cali y a $526 \mathrm{~km}$ de Bogotá. Cuenta con el territorio más extenso del departamento del Valle del Cauca, con un total de $6078 \mathrm{~km}^{2}$. Limita al norte con el

\footnotetext{
${ }^{4}$ San Buenaventura de Fidanza: Santo y místico franciscano, obispo de Albano y cardenal italiano, venerado en la iglesia católica y patrono de Buenaventura Valle del Cauca.
} 
departamento del Chocó, al sur con el departamento del Cauca, al occidente con el Océano Pacífico y al oriente con los municipios de Jamundí, Dagua, Calima Darién y Cali. (Alcaldía Distrital de Buenaventura, 2016, p.1).

Como gran parte de la costa pacífica colombiana, Buenaventura se encuentra separada del interior del país por la cordillera occidental de los Andes, en la llanura del pacífico. La gran mayoría de su territorio está por debajo de los 1000 metros sobre el nivel del mar. Cuenta con un clima cálido muy húmedo. La mayor parte del territorio bonaverense, está cubierto de selvas y cruzado por numerosos y caudalosos ríos. Entre sus principales, están los ríos Achicayá, Bongo, Cajambre, Calima, Dagua, Guapi, Guapicito, La Sierpe, Mayorquino y Naya. Los corregimientos más importantes son: Bahía Málaga y Bahía Buenaventura. Sus principales productos son el oro, el pescado y la medara, debido a las principales actividades económicas de la zona como son: El movimiento portuario, La explotación forestal, la pesca marina y fluvial, minería, reservas petrolíferas y comercio. (Gobernación del Valle del Cauca, 2006, p.1).

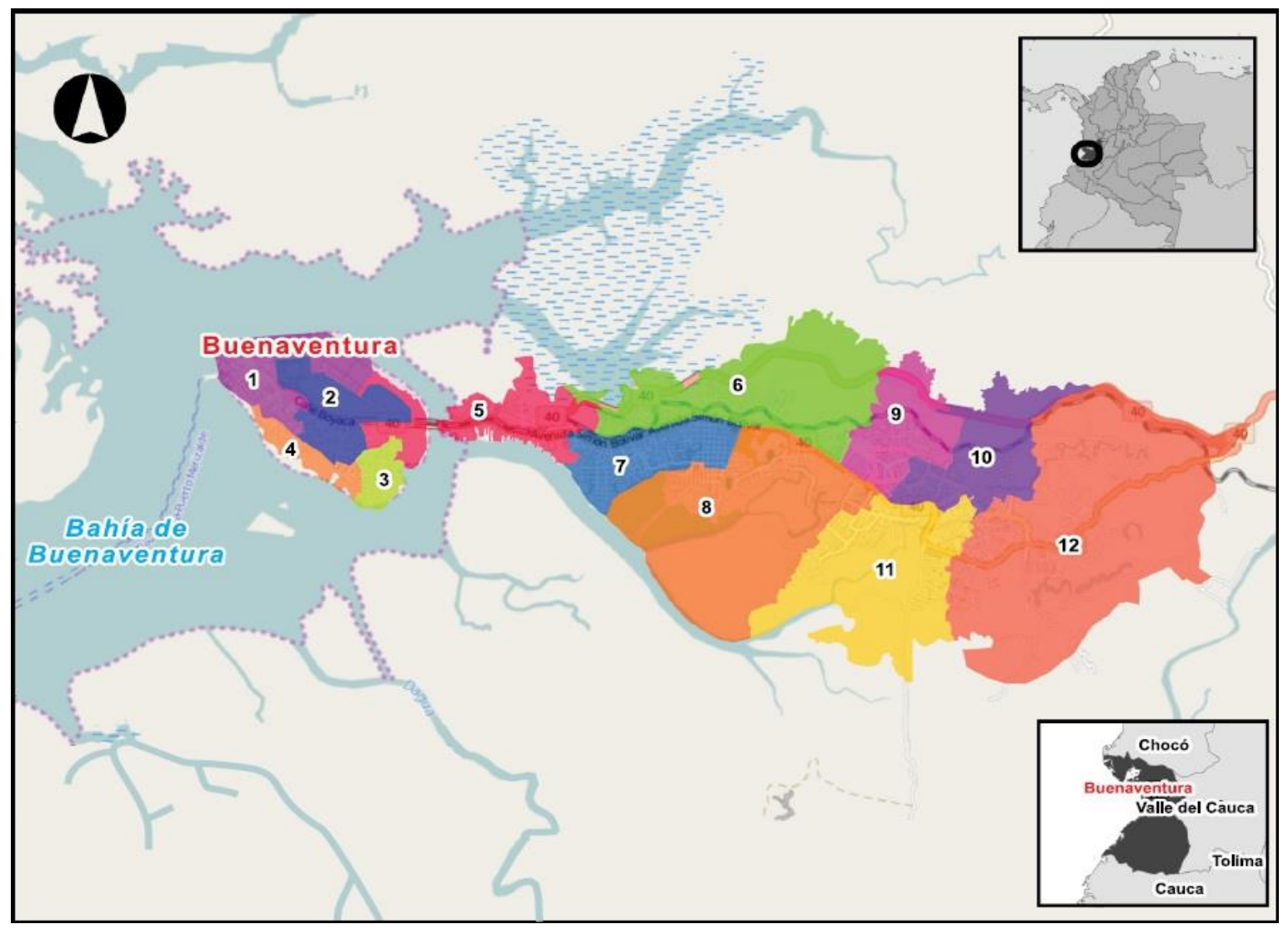

Gráfico 1. Tello, E. (2016) Mapa 1. Buenaventura, comunas. [Mapa]. Recuperado de http://library.fes.de/pdffiles/bueros/kolumbien/12685.pdf y http://www.academia.edu/36145689/Violencia_desarrollo_y_despojo_en_Buenaventura

Comunas de Buenaventura Valle del Cauca: Comuna 1: Nayta, Centenario, La Isla. Comuna 2: Vientos Libres Norte, Monte Chino, El Firme, Capricho, Francisco de Paula Santander, El Jorge, Borrero Olano, Santa Rosa. Comuna 3: Alfonso López Pumarejo, Alberto Lleras Camargo. Comuna 4: San José, Muro Yusty, Vientos Libres Sur, Campo Alegre, La Playita. Comuna 5: Pascual de Andagoya, La Palera, Punta del Este, Santa Cruz, La Inmaculada, Santa Fe, Miramar. Comuna 6: El Porvenir, El Campin, El Jardín, Brisas del Mar, Miraflores, El Oriente, Isla de la Paz, Barrio Naval, Bosque Municipal, La Comuna. Comuna 7: Kennedy, San Luis, San Francisco, Municipal, Juan XXII, Eucarístico, Rockefeller, 14 de Julio. Comuna 8: Modelo, María Eugenia, Bella Vista, Olímpico, El Cristal, 
Transformación, Los Laureles, Ciudadela Colpuertos. Comuna 9: San Buenaventura, Doña Cesi, 12 de Abril, 6 de Enero, Turbay Ayala, Nueva Buenaventura. Comuna 10: Independencia, Urbanización Acuarela, Carlos Holmes, Las Américas, Bolívar, Camilo Torres, Urbanización Bahía, El Progreso, La Fortaleza, Urbanización Comunitaria, Los Álamos, Urbanización Comfamar, Bello Horizonte. Comuna 11: El Dorado, Antonio Nariño, Cascajal, El Carmen, Nueva Colombia, Los Pinos, Panamericano, Gran Colombiana, Cristóbal Colon, El Futuro. Comuna 12: Puerto del Mar, Alfonso López Michelsen, Unión de Vivienda, El Triunfo, 20 de Julio, El Reten, Nueva Granada, Las Palmas, Nueva Frontera, Matia Murumba, Cabal Pombo, El Caladas, La Libertad, La Gloria, La Unión, El Ruiz, Rafael Uribe, El Cambio, Nuevo Amanecer, La Campiña, Vista Hermosa, Jorge Eliecer Gaitán, La Dignidad, Brisas del Pacifico, 12 de Octubre.

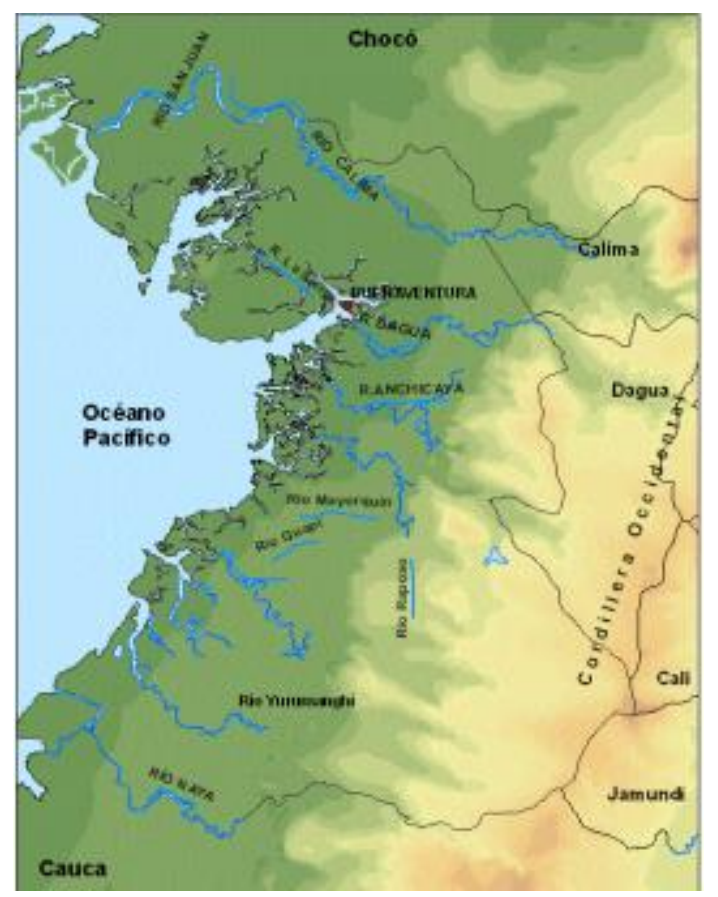

Gráfico 2. Fedesarrollo-CERAC. (2013). Capital Natural y Diagnóstico Ambiental [Mapa]. Recuperado de https://www.repository.fedesarrollo.org.co/bitstream/handle/11445/198/Hacia\%20un\%20desarrollo\%20integral\%20de\%20la\%20ciudad $\% 20 \mathrm{de} \% 20$ Buenaventura $\% 20 \mathrm{y} \% 20$ su $\% 20$ area $\% 20 \mathrm{de} \% 20$ influencia $\% 20-\% 20$ Informe $\% 20$ final $\% 202013$.pdf? sequence=2

\section{Aspectos Económicos}

Buenaventura pese a tener el más extenso territorio del departamento vallecaucano, presenta un porcentaje desfavorable en cuanto a su fertilidad. Como lo menciona Pérez (2007), “el $(68,3 \%)$ se encuentran clasificados como de muy baja fertilidad, situación que limita significativamente las posibilidades de desarrollo de las actividades agrícolas” (p.13).

Los puertos marítimos son esenciales para el desarrollo de un Estado, por los puertos ingresan las materias primas, mercancías, tecnología y demás productos necesarios para generar el progreso y desarrollo. Además, son una fuente grande de empleo y de interacción con el mundo. Pese a las ventajas que trae un puerto marítimo el de Buenaventura al ser el principal de Colombia está lejos de generar estos beneficios. La economía bonaverense se puede interpretar que está compuesta por la unión de dos circuitos económicos ${ }^{5}$ precarios

${ }^{5}$ Compuestos por los mercados, capitales y personas involucrados en el desarrollo de las actividades productivas que los conforman, de tal forma que estos están integrados por actividades y cadenas productivas que mantienen interdependencias. 
que son el portuario y el local. Según el Centro Nacional de Memoria Histórica (2015), el portuario es aquel que contiene la economía marítima y la logística portuaria, mientras el local, está compuesto por los sectores productivos tales como la pesca, la agricultura, el ecoturismo, la industria, el sector maderero y forestal, y la economía tradicional.

En este circuito local los hombres trabajan como pescadores y viven del mar. Las mujeres en cambio se encargan de comercializar la piangua, mariscos, cocadas, chontaduros y frutas. También, este circuito local aglomera poblaciones de afrodescendientes de Buenaventura e incluso de la ciudad de Cali. El circuito local se contrasta con el circuito portuario dado que presentan distintas actividades económicas y el portuario ha recibido inversiones del Estado. Por su parte, el circuito local no tiene las mismas garantías, estabilidad y presenta abandono del Estado. Ha sido el que más se ha afectado por los repertorios de violencia de terror, desterritorialización e invisibilización desarrollados en el marco del conflicto armado. (Centro Nacional de Memoria Histórica, 2015, p.57).

Los problemas económicos narrados anteriormente han causado, una desigualdad en la distribución del ingreso. Otro problema social en la ciudad puerto. El dinero producido en Buenaventura se concentra en unas pocas personas y genera pobreza extrema en otras. Como lo afirma el Centro Nacional de Memoria Histórica (2015), la población de Buenaventura vive en la pobreza, la desigualdad y en precarias condiciones careciendo servicios de salud, educación, vivienda y servicios públicos los cuales son vulneran los derechos humanos.

Según lo anterior el municipio padece de gran cantidad de necesidades desde sus servicios públicos precarios, que no cubren la totalidad de las necesidades de su población, hasta una educación poco inclusiva generando analfabetismo en el puerto de acuerdo con DANE (2005) citado por Fedesarrollo-CERAC (2013, p.16), menciona que "en el 2005 la tasa de analfabetismo de Buenaventura era de 9,2\% casi el doble de la del Valle del Cauca y superior a la del conjunto del país". ${ }^{6}$

La poca presencia del gobierno a través de sus instituciones y autoridades, impide tener adecuadas carreteras que faciliten el descargue y desplazamiento, de mercancías y materiales que llegan por el puerto hacia el interior del País. Además de la necesaria modernización que requiere el puerto para cubrir la demanda de los barcos con contenedoras más amplios y modernos. Estos problemas generados por la poca inversión del estado colombiano generan un estancamiento del puerto y del municipio.

\section{Conflicto Armado en Buenaventura}

En capítulos anteriores la ubicación geográfica está relacionada con la violencia en Buenaventura porque la ciudad puerto se convirtió en un corredor estratégico al contar con salida al océano pacífico y poseer amplias rutas fluviales, lo cual facilita la salida de drogas

\footnotetext{
${ }^{6}$ Fedesarrollo-CERAC. (2013). Hacia un Desarrollo Integral de la Ciudad de Buenaventura y su Área de Influencia. Recuperado de https://www.repository.fedesarrollo.org.co/bitstream/handle/11445/198/Hacia\%20un\%20desarrollo\%20integral\%20de\%20la\%20ciudad $\% 20 \mathrm{de} \% 20$ Buenaventura $\% 20 \mathrm{y} \% 20$ su\%20area\%20de \%20influencia\%20-\%20Informe $\% 20$ final $\% 202013$.pdf? sequence=2
} 
por parte de los grupos armados ilegales que ven un lugar valioso y este va más allá de una ruta del narcotráfico, debido a que en la zona -como se mencionó en el capítulo anteriorBuenaventura cuenta con abundantes recursos naturales, como por ejemplo la explotación maderera, petrolera, y la minera. Estas dos últimas actividades también se han explotado ilegalmente por los grupos al margen de la ley para financiar sus actividades ilícitas en el sector.

La violencia en Buenaventura es causada por grupos armados ilegales como las guerrillas [FARC y ELN], los paramilitares, las bandas criminales y la delincuencia local. De 400 mil habitantes, más de 160 mil se han acreditado como víctimas; entre 1999 y $2003^{7}$. Este problema se debió a la débil y frágil soberanía ejercida por el Estado.

No se tiene una precisión exacta de cuando llegaron los grupos armados al margen de la ley a Buenaventura Valle del Cauca, pero los siguientes informes presentan una serie de momentos claves del arribo de los grupos armados ilegales a la ciudad portuaria.

Según Riascos Rodgers (2012), en la época de la violencia bipartidista entre conservadores y liberales y tras la muerte de Jorge Eliecer Gaitán, en Buenaventura hacia los años 70 llegaron las FARC de una manera sigilosa a la zona rural de Buenaventura, que fue siempre de ideología liberal. Para el diario El Espectador, en su informe noticioso titulado "Buenaventura 14 años de Violencia"

son tres momentos claves que explican cómo se originó la violencia en el puerto: En 1990 llegaron las FARC, en 1999 llegaron los paramilitares representados por el Bloque Calima y en el año 2004 se dio su desmovilización.

El grupo guerrillero del ELN también hace presencia en la zona, según el informe de la Defensoría del Pueblo (2003), "la Columna Simón Bolívar del ELN acciona en el centro y noroccidente del departamento y la José María Becerra, del mismo grupo armado ilegal, en los Farallones de Cali." 8

Mientras que para el informe Fedesarrollo-CERAC (2013), son cuatro momentos claves en la historia del contexto violento de Buenaventura Valle del Cauca. El primer momento se da en 1980 a 1999, en este periodo llegó el bloque 30 de las FARC, se asentó en las zonas rurales de Buenaventura, cerca de los ríos Dagua y Calima. Se creó este bloque por órdenes del Comando Conjunto Central de las FARC que operaba en los departamentos del Cauca y Tolima.

El bloque 30 mantuvo una actividad de baja intensidad en la zona pero a partir de 1997 su nivel de hostilidad aumentó drásticamente, realizó ataques a la fuerza pública, e infraestructura energética, durante este año se creó la Columna Móvil Manuel Cepeda (CMMC), se caracterizó porque mediante esta agrupación las FARC ingresaron a los barrios marginados de Buenaventura como milicias urbanas. Este cambio de parecer de las

\footnotetext{
7 Gutiérrez E. (05 de junio de 2015). Buenaventura 14 años de violencia. El Espectador. Recuperado de: https://www.elespectador.com/noticias/nacional/buenaventura-14-anos-de-violencia-articulo-564875

${ }^{8}$ Defensoría del Pueblo (septiembre de 2003) Resolución Defensorial Regional. Sobre la situación de derechos humanos de la población desplazada en el municipio de Buenaventura Bogotá D.C. (017), [p.3]. doi: http://www.defensoria.gov.co/attachment/256/regional17.pdf
} 
FARC fue motivado por el posicionamiento del Puerto como punto estratégico económico no solo para el gobierno nacional sino también para las demás agrupaciones criminales y por el debilitamiento del Cartel de Cali. La guerrilla de las FARC vio en Buenaventura un lugar estratégico de gran valor para financiar sus actividades ilícitas y controlar las rutas destinadas al tráfico de armas y drogas por vías marítimas, fluviales y terrestres.

El segundo momento va desde 1999 a 2004, en el que llegaron los grupos paramilitares a la ciudad portuaria a través del Frente Pacífico del Bloque Calima para contrarrestar el accionar y el dominio de las FARC sobre las rutas de acceso que conducen a Cali y el río Naya. Los grupos paramilitares fueron creados con el apoyo del Cartel del Norte del Valle y de sectores empresariales que habían sufrido extorsiones y acciones violentas por parte de las FARC y otros grupos guerrilleros de la zona.

Como lo menciona Fedesarrollo-CERAC (2013), "En una primera etapa su accionar se concentró en las cuencas de los ríos Naya, Yurumanguí, Anchicayá, Raposo, Cajambre y Calima, así como en la Comuna 12. Allí, el Frente Pacífico realizó masacres, asesinatos selectivos y desplazamientos forzados que afectaron a personas señaladas de colaborar con las FARC" (p.153). Luego de las confrontaciones armadas por la disputa del control de los barrios bonaverenses, el Frente 30 de las FARC se vio obligado a replegarse a la zona rural por la presión armada ejercida a cargo de las AUC.

El tercer momento va desde el año 2004 al 2009, el cual presentó dos etapas. La primera etapa, estuvo marcada por la desmovilización del Bloque Calima y la emergencia de los Grupos Pos Desmovilización Paramilitar (GPDP), en este periodo se finalizó las confrontaciones entre paramilitares y la guerrilla de las FARC en Buenaventura pero el conflicto armado continuó por la fallida desmovilización del Bloque Calima en el año 2004, la cual de 800 hombres armados que conformaron el Bloque Calima se desmovilizaron 564; el restante según este informe Fedesarrollo-CERAC (2013), continuaron delinquiendo algunos fueron reclutados por el frente 30 de las FARC, grupos al servicio del narcotráfico y otros se rearmaron como nuevos grupos paramilitares tales como las Águilas Negras y Los Rastrojos.

La segunda etapa, consistió en el deseo de las FARC por recuperar el control del área urbana de Buenaventura y los grupos pos desmovilización paramilitar junto con los grupos de narcotraficantes en impedírselo. Esto ocasionó en la ciudad puerto una confrontación armada entre estos grupos armados ilegales por tomar el control de los barrios de bajamar ${ }^{9}$ de Buenaventura.

Sumado a lo anterior, también se fortalecieron enfrentamientos entre la fuerza pública contra las FARC, debido al incremento en el pie de fuerza de las FFAA dentro del marco de La Política De Seguridad Democrática y en respuesta a esta ofensiva militar los milicianos de las FARC desplegaron un "plan pistola" contra policías y miembros del ejército

\footnotetext{
${ }_{9}$ Viviendas populares en Buenaventura colindantes con el mar al subir la marea, como por ejemplo los barrios de La Playita. El Muro, Juan 23, Cristal, Punta del Este, entre otros.

${ }^{10}$ Orden emitida por grupos armados ilegales de arremeter contra integrantes de la fuerza pública de Colombia como represaría ante alguna medida de seguridad adelantada.
} 
nacional. Este conflicto ocasionó que hacia el año 2007 las FARC se replegaran de la zona urbana de Buenaventura por el accionar de los Grupos Pos Desmovilización Paramilitar, grupos de narcotraficantes y la fuerza pública.

Por último, el cuarto momento según el presente informe, correspondió del año 2009 al 2013, este se dividió a su vez en dos periodos, el primero de 2009 a 2012, cuando se asociaron los grupos criminales de Los Rastrojos y La Empresa. Con esta alianza se hicieron del dominio de los barrios de Buenaventura y ocasionó la retirada definitiva de las FARC del casco urbano de la ciudad portuaria. El segundo periodo, correspondiente a octubre de 2012 hasta la fecha, en el cual la disputa por zona urbana bonaverense es entre los grupos criminales de Los Rastrojos, Los Urabeños y grupos pos desmovilización paramilitar.

De los anteriores informes se puede concluir que Buenaventura se convirtió en un botín de guerra para los grupos armados ilegales que buscan financiar su accionar en la región puesto que la ciudad portuaria cuenta con distintas vías marítimas, fluviales y terrestres, que facilitan el tráfico de armas y narcotráfico. Buenaventura cuenta además, con recursos naturales como minería y yacimientos petroleros los cuales son explotados ilegalmente por los grupos armados al margen de la ley y sumado a esto una desprotección estatal que posibilita el accionar de estos grupos armados.

La violencia en el puerto se manifiesta con una alta tasa de homicidios, pero no siempre fue así, según PNUD (2008) citado por Fedesarrollo-CERAC (2013, p.24), en el año 1991 la tasa de homicidios en Buenaventura era intermedia de (77 por cada 100.000 habitantes), pero a partir del año 2003 se agudizó la violencia reflejada en una de las tasas de homicidios más altas a nivel distrital, departamental y nacional. Como también lo reportó el periódico El País huyeron de la zona rural al casco urbano unas 14.300 personas desplazadas por la violencia y es allí donde en el año 2003 se incrementó la violencia dejando una cifra de 384 homicidios en la ciudad portuaria.

\begin{tabular}{|c|c|c|c|c|c|c|}
\hline \multicolumn{7}{|c|}{ Tasa de Homicidio, Buenaventura, Cali, Valle y Nacional. 2003-2008 } \\
\hline & 2003 & 2004 & 2005 & 2006 & 2007 & 2008 \\
\hline Buenaventura & 98.2 & 95,1 & 89,4 & 121,6 & 91,2 & 59,0 \\
\hline Cali & 91,9 & 91,3 & 74,7 & 71,8 & 68,4 & 63,1 \\
\hline Departamental & 90,2 & 94,9 & 84,9 & 82,3 & 77,0 & 70,3 \\
\hline Nacional & 52,8 & 44,6 & 42,2 & 40,3 & 39,1 & 36,3 \\
\hline \multicolumn{7}{|c|}{$\begin{array}{l}\text { Fuente: Policía Nacional Procesado: Observatorio del Programa Presidencial de DH y } \\
\text { DIH, Vicepresidencia de la República. Las tasas de homicidio de } 2003 \text { y } 2004 \text { se } \\
\text { calcularon con la población proyectada por el Dane del censo 1993, mientras que las } \\
\text { tasas entre } 2005 \text { y } 2008 \text { se calcularon con base en la población proyectada del censo } \\
2005 \text {. }\end{array}$} \\
\hline
\end{tabular}

Gráfico 3. Fedesarrollo-CERAC. (2013). La Violencia Homicida. [Grafico]. Recuperado de

https://www.repository.fedesarrollo.org.co/bitstream/handle/11445/198/Hacia\%20un\%20desarrollo\%20integral\%20de\%20la\%20ciudad $\% 20 \mathrm{de} \% 20$ Buenaventura $\% 20 \mathrm{y} \% 20$ su $\% 20$ area $\% 20 \mathrm{de} \% 20$ influencia $\% 20-\% 20$ Informe $\% 20$ final $\% 202013$.pdf? sequence $=2$ 
Por su parte la tasa de homicidios del municipio de Buenaventura según el Instituto Nacional de Medicina Legal y Ciencias Forenses (2005), de 278.960 habitantes, 324 casos y con una tasa de $116 .^{11}$

La débil respuesta del Estado facilitó las acciones criminales por parte de los grupos armados ilegales, como las 26 masacres cometidas por los paramilitares ${ }^{12}$ entre el 2000 y 2003, donde cerca de 153.000 personas han sido desplazadas, siendo la ciudad con el mayor índice de desplazamiento interurbano de Colombia ${ }^{13}$. La ubicación geográfica de Buenaventura siempre fue atractiva para los grupos armados ilegales puesto que vieron cómo lucrarse a través de actividades ilícitas como el narcotráfico, la minería ilegal y el robo de combustible. En consecuencia, el deseo de los grupos armados ilegales en controlar a Buenaventura y a su población.

Esa ambición se evidencia en el llamado "período de las mil muertes" ${ }^{14}$ donde alias H.H. ordenó asesinar a mil personas para controlar a través del terror a la población de Buenaventura, sin importar como se produjeran las muertes. En este período sucedieron las 26 masacres. $^{15}$

Fue con los paramilitares al mando de Hebert Veloza García, alias "H.H” donde empezaría la pesadilla y se viviría el punto más alto de violaciones de los derechos humanos en el puerto, cuando alias "H.H” comando al Bloque Calima ${ }^{16}$.

El Bloque Calima fue un grupo paramilitar adscrito a las Autodefensas Unidas de Colombia. Su primer comandante fue David Hernández Rojas o alias "39" o "José”, el cual fue reemplazado por Hebert Veloza García o alias "H.H”, debido a que alias "39” se enfocó más en socorrer a los narcotraficantes de la zona y descuido el accionar de contrainsurgencia guerrillera, por lo cual los hermanos Castaño ordenaron su reemplazo.

El Bloque Calima se creó en el año 1999 bajo el mando de alias “39" o "José” pero desde el año 2000 al 2004 lo comandó alias "H.H." En este periodo fue donde se incrementó considerablemente su accionar contra las FARC y grupos guerrilleros y principalmente sus hostigamientos a la población civil de Buenaventura bajo el discurso antisubversivo. El Bloque Calima operó en los departamentos del Valle del Cauca, Cauca y en menor medida

\footnotetext{
${ }^{11}$ Instituto Nacional de Medicina Legal y Ciencias Forenses. (2005). Forensis Datos para la Vida. Homicidio, [p.71]. Recuperado de http://www.medicinalegal.gov.co/documents/20143/49493/Homicidio.pdf

${ }^{12}$ Centro Nacional de Memoria Histórica-CNMH. (2015). Buenaventura: Un Puerto sin Comunidad. (p 232).

${ }^{13}$ Centro Nacional de Memoria Histórica-CNMH, (08 de marzo de 2018). La Resistencia de Buenaventura. Noticias CNMH. Recuperado de http://www.centrodememoriahistorica.gov.co/noticias/noticias-cmh/la-resistencia-de-buenaventura

${ }^{14}$ Caracol Radio. (04/09/08). Alias "HH” confiesa que las AUC asesinaron a más de mil personas en Buenaventura. Judicial. Recuperado de http://caracol.com.co/radio/2008/09/04/judicial/12205250040_664894.html

15 Gutiérrez E. (05 de junio de 2015). Buenaventura 14 años de violencia. El Espectador. Recuperado de: https://www.elespectador.com/noticias/nacional/buenaventura-14-anos-de-violencia-articulo-564875

${ }^{16}$ El Bloque Calima, fue un grupo paramilitar adscrito a las Autodefensas Unidas de Colombia (AUC) que operó en los departamentos de Valle del Cauca y Cauca, así como en algunos municipios de Risaralda, Quindío y Huila entre 1999 y 2004,Centro Nacional de Memoria Histórica (2018), Bloque Calima de las AUC. Depredación paramilitar y narcotráfico en el suroccidente colombiano. Informe No. 2, Bogotá, CNMH.
} 
en algunos municipios del Quindío y Risaralda. En el año 1999 el Bloque estuvo dividido en cuatro frentes hasta el año 2000 donde se dividió en cinco frentes; Pacífico, Central, Farallones, La Buitrera y Calarcá. ${ }^{17}$

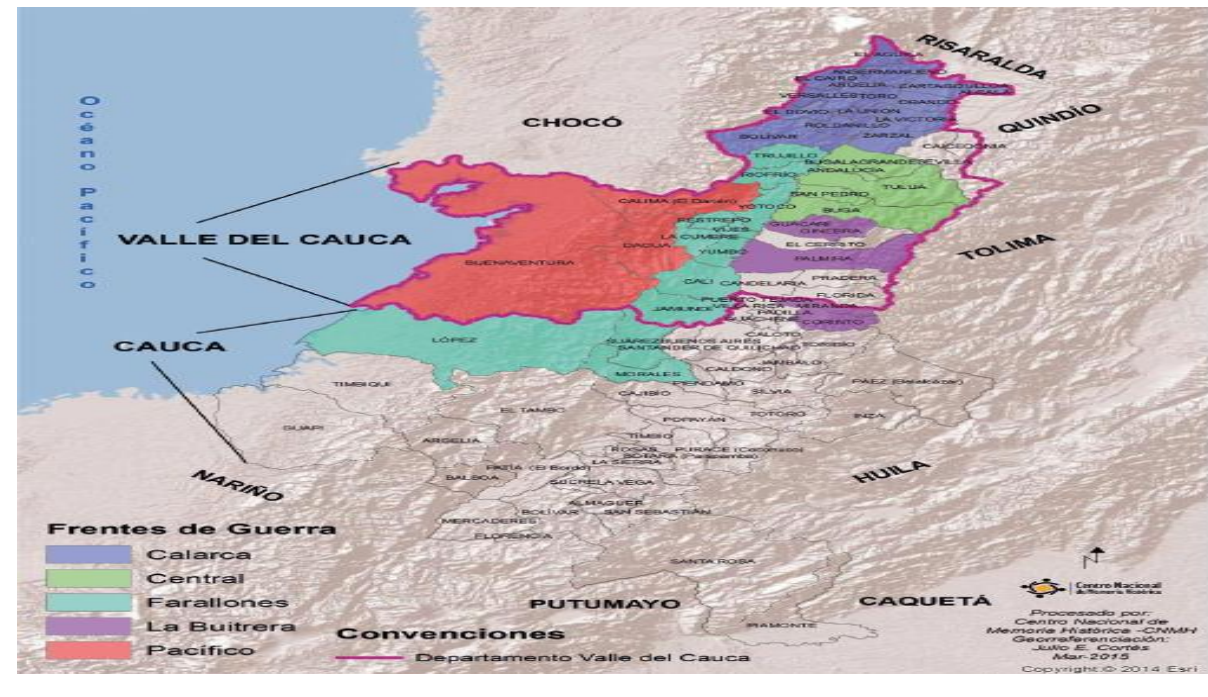

Gráfico 4. Centro Nacional de Memoria Histórica. (2015). Mapa 1 Bloque Calima. [Mapa]. Recuperado de: http://www.centrodememoriahistorica.gov.co/micrositios/buenaventura/

1. Frente Central o Tuluá (1999). Que tuvo influencia en Tuluá, Buga, Buga la Grande, San Pedro y Andalucía. 2. El Frente Calarcá (2000), que operó en el norte del Valle del Cauca. 3. El Frente la Buitrera (1999), cuyo centro de operaciones fue el corregimiento la Buitrera - Palmira, desde donde ejercicio dominio sobre Ginebra, Guacarí, Miranda y Corinto. 4. El Frente Farallones, que operó en la cordillera occidental. 5. El Frente Pacífico (1999), que operó en los municipios de Buenaventura, Darién y Dagua.

Los integrantes del Bloque Calima más precisamente su Frente Pacífico son responsables de la masacre de Sabaletas el 11 de mayo de 2000, donde fueron asesinadas 13 personas y sus posteriores descuartizamientos, como también se les atribuye el desplazamiento forzoso de 2.500 personas. Aunque para otros investigadores la primera acción militar que hizo el Bloque Calima en Buenaventura fue el asesinato de alias "Cholopablo" en el barrio Rockefeller, presunto comandante del frente 30 de las FARC. ${ }^{18}$

El Bloque Calima llegó al departamento del Valle del Cauca gracias a una alianza entre los narcotraficantes según el Centro Nacional De Memoria Histórica en sus informes titulados "Buenaventura un Pueblo Sin Comunidad" y "Justicia y Paz ¿Verdad Judicial o Verdad Histórica?" fueron Alias “Gordolindo", Víctor Patiño Fómeque, Luis Fernando Gómez, alias "Rasguño", Arcángel de Jesús Henao, alias "El Mocho” y Diego León Montoya, alias "Don Diego" este último fue el líder de los grupos ilegales de "Los Machos"19" y "Los Yiyos $^{20 "}$.

\footnotetext{
${ }^{17}$ Centro Nacional de Memoria Histórica-CNMH. (2015). Buenaventura: Un Puerto sin Comunidad. (p.165).

${ }^{18}$ Centro Nacional de Memoria Histórica (2018), Bloque Calima de las AUC. Depredación paramilitar y narcotráfico en el suroccidente colombiano. Informe No. 2, Bogotá, CNMH.

${ }^{19}$ Grupo armado delincuencial liderado por alias Don Diego que operó en el Valle del Cauca.

${ }^{20}$ Agrupación sicarial armada liderada por alias Don Diego que opera en el sur del Valle del Cauca, según informe de la CNRR.
} 
Estos narcotraficantes fueron responsables de facilitar el ingreso del Bloque Calima al Valle del Cauca. Según declaraciones de paramilitares que se acogieron a la Ley de Justicia y Paz (975 de 2005), los narcotraficantes con los alias de "Don Diego", "El Mocho" y "Rasguño" fueron los que financiaron principalmente el arribo del Bloque Calima al departamento vallecaucano, entregándoles sumas de dinero, equipamientos y provisiones a cambio de que estos contrarrestaran el accionar de las FARC más precisamente cuidando sus laboratorios de drogas. ${ }^{21}$

Cuando se anunció la desmovilización del Bloque Calima en el año 2004 parecía que por fin se terminaba el terror paramilitar, había optimismo y alegría en los bonaverences de encontrar la paz pero poco fue lo que duró su esperanza ya que quedaba la ambición por controlar las rutas del narcotráfico en algunos ex combatientes del Bloque Calima los cuales formaron la organización criminal conocida como "La Empresa" al servicio de Los Rastrojos y rápidamente se apoderaron de los barrios del puerto.

Para el año 2012, aparecen los Urabeños ${ }^{22}$ hoy en día el Clan Úsuga y consigo traen de nuevo el régimen del terror a las calles de Buenaventura. El puerto sería entonces testigo de la ola de asesinatos entre los miembros de ambas organizaciones criminales lideradas por narcotraficantes con antecedentes de haber pertenecido a las organizaciones criminales más temibles del país como El Cartel de Cali, La oficina de Envigado, Los Hermanos Úsuga, entre otras. Estos grupos al margen de la ley son responsables de homicidios, desplazamientos forzados, extorsiones, narcotráfico, tortura, entre otros. Este último delito, ha impactado a las principales autoridades del país y a la población civil, con las llamadas "Casas de Pique" 23 en las cuales se torturaban, asesinaban y descuartizaban personas para luego ser arrojados sus restos al mar o a los ríos aledaños, práctica que se hizo muy común en Buenaventura en la guerra por el control de las rutas del narcotráfico entre las organizaciones delincuenciales de La Empresa y El Clan Úsuga.

\footnotetext{
${ }^{21}$ La Fiscalía cuenta con un escrito fechado el 5 junio de 2000 , dirigido por el comandante Román a los miembros del Estado Mayor de las ACCU (Autodefensas Campesinas de Córdoba y Urabá), donde les dice que los narcotraficantes están en capacidad de aportar 50 millones de pesos al año.

${ }^{22}$ Grupo armado ilegal con presencia nacional, que se formó de disidencias de grupos paramilitares tras acuerdos de paz con el gobierno nacional y muertes de sus principales comandantes.

${ }^{23}$ Práctica que empezó con el cartel de Medellín y la guerra que libró contra el Estado y la organización paramilitar de los Pepes. En Buenaventura son casas donde se tortura, se descuartizan y se arrojan al mar los cuerpos de personas.
} 


\begin{tabular}{|l|l|c|c|c|}
\hline \multicolumn{1}{|c|}{ Masacre } & $\begin{array}{c}\text { Nümero de } \\
\text { victimas }\end{array}$ & $\begin{array}{c}\text { Nümero de } \\
\text { desaparecidos }\end{array}$ & Año \\
\hline 1 & De Sabaletas & 13 & - & 2000 \\
\hline 2 & De Campo Hermoso & 4 & 6 & 2000 \\
\hline 3 & De Cascajal (barrio de Buenaventura) & 5 & - & 2000 \\
\hline 4 & Veredas Katanga y Los Tubos & 7 & - & 2000 \\
\hline 5 & De Zaragoza & 7 & - & 2000 \\
\hline 6 & De Las Palmas & 6 & - & 2000 \\
\hline 7 & De Cisneros y Peñitas & 9 & - & 2000 \\
\hline 8 & De Citronela & 4 & - & 2001 \\
\hline 9 & De El Firme & 7 & - & 2001 \\
\hline 10 & De Obrero (barrio de Buenaventura) & 8 & - & 2002 \\
\hline 11 & De Muro Yutsy (barrio de Buenaventura) & 4 & - & 2002 \\
\hline 12 & De Bajo Calima & 5 & - & 2002 \\
\hline 13 & De Sabaletas & 6 & - & 2003 \\
\hline 14 & De El Triunfo & 4 & & - \\
\hline 15 & En el casco urbano de Buenaventura (no se especifica el lugar) & 5 & & 2003 \\
\hline 16 & De Yurumanguí & 12 & & 2004 \\
\hline 17 & De Lleras (barrio de Buenaventura) & & - & 2005 \\
\hline
\end{tabular}

Gráfico 5. Valencia, H. Silva, L. Moreno, A. (2016) Tabla 1. Masacres cometidas por las autodefensas en Buenaventura entre $2000 \mathrm{y}$ 2005 [Tabla]. Recuperado de: http://library.fes.de/pdf-files/bueros/kolumbien/12685.pdf 


\section{CAPÍTULO II}

\section{HECHOS}

Luis Ángel Sinisterra Viveros, nació en Buenaventura Valle del Cauca, hace 57 años. Don Ángel tiene más de 10 años trabajando como líder social luchando por el respeto de los derechos humanos y por los afrocolombianos. Por tal motivo creó la Asociación Afro Víctima del conflicto del Tolima, (ASFROVICTOL) con la cual realiza actividades como el acompañamiento jurídico para garantizar el cumplimiento del Decreto Ley 4635 de 2011, el cual establece la asistencia, atención, reparación integral y de restitución de tierras a las víctimas pertenecientes a comunidades negras, afrocolombianas, raizales y palenqueras.

También el cumplimiento de normas y políticas públicas a nivel municipal, departamental y nacional con contenido étnico principalmente relacionadas con los afrocolombianos. Esta iniciativa de ayudar a su comunidad se debió a lo que vivió Don Ángel Sinisterra como víctima del conflicto armado en Buenaventura Valle del Cauca tuvo que vivir desplazado en la ciudad de Ibagué Tolima. Donde observó que había más afrocolombianos víctimas del conflicto armado como él. Muchos mendigando en las calles, por ello se interesó por acompañar los procesos de exigibilidad de derechos y asumir el liderazgo. En ese marco, varias personas de la comunidad afrodescendiente desplazados lo eligieron para representarlos en la mesa de víctimas a nivel municipal y departamental para que los afros que están pasando necesidades y en la indigencia puedan tener mejores condiciones de vida, como servicios de salud, educación, trabajo y vivienda.

Desde que era un joven se interesó por participar en eventos comunitarios, cuidando de sus familiares, amigos y vecinos. Interesado por ser un líder y darse a conocer en su barrio. Esa motivación de ayudar y preocuparse por los demás lo llevó a entrar a la policía nacional, donde fue agente profesional y así seguir ayudando a las demás personas.

Ángel Sinisterra luego ingresó a trabajar en el puerto de Buenaventura, dada su vocación como líder de temperamento fuerte, acostumbrado a decir lo que pensaba, a no callar ante las injusticias. Condiciones por las cuales fue elegido por los trabajadores del puerto como su líder sindical. Ya como líder afrontó los abusos laborales, discriminación, y desprotección que existía entre los trabajadores portuarios con los empleadores. Pese a ello, el señor Ángel también fue líder social en el barrio donde vivió allí Buenaventura, en el año 2005 donde observó cómo los paramilitares hacían presencia, extorsionando, reclutando y amenazando a los habitantes del sector. Don Ángel se opuso a su accionar, denunciando ante autoridades competentes y además comunicándoles a sus vecinos sobre este problema que se venía presentando en el sector. Fue entonces donde empezó a recibir amenazas de atentar contra su vida.

En el mes de marzo del año 2005 el señor Ángel Sinisterra se encontraba en el pleno centro de Buenaventura, cuando unos sujetos lo abordaron y le manifestaron que si podían hablar 
y lo convencieron de subir a un taxi; pasados unos minutos del recorrido lo trasladaron a los barrios de bajamar, específicamente al barrio El Cristal. Es en este preciso momento donde comenzaron los sujetos a propinarle puños en su rostro y torso mientras el taxi continuó en movimiento, además fue abofeteado cuando los perpetradores notaron que Don Ángel guardó silencio ante estos tratos acompañados de insultos y amenazas.

Según Sinisterra Viveros estas zonas de bajamar estuvieron ocupadas por los paramilitares. Ya en este lugar, lo engañaron trasladándolo a la fuerza a la playa donde lo dejaron atado de pies y manos sobre una lancha. ${ }^{24}$ Posteriormente comenzaron a golpearlo propinándole puños y puntapiés en todo su cuerpo. Incluso estos sujetos se turnaron para golpearlo. Además en reiteradas ocasiones le dijeron que lo iban a matar y a su familia también le iban a hacer lo mismo.

Llegaron en un taxi amarillo y me dicen: súbase al carro que necesitamos hablar con usted. Yo pensé que era una charla normal cuando ya me meten al sector de ellos, donde ellos mandan pues ya me decían que “'Vos sos el que no está de acuerdo con nosotros?” y ya me van golpeando, pegando patadas, puños. Me golpearon los integrantes de ese comando paramilitar que operaban allá al mando de ese señor "Tábano".

A mí me detuvieron marzo de 2005 no me acuerdo bien por el trauma que uno tiene es muy grande, fue en la mañana. Me acuerdo que fue un día sábado, me pegaron unas cachetadas como para que yo reaccionara pero yo nunca reaccioné. Me golpearon los integrantes de ese comando paramilitar que operaban allá al mando de ese señor "Tábano", eran como 15 y cada 20 minutos me golpeaban durante un día y medio...

Ángel Sinisterra, Entrevista 28 de marzo de 2017.

El comando paramilitar sometió a Don Ángel a tortura física durante dos días y como lo afirma Don Ángel, la tortura psicológica fue determinante en su vida:

La tortura física duraron dos días y ya la psicológica todo un tiempo.

Ángel Sinisterra, Entrevista 28 de marzo de 2017

Luego de permanecer dos días retenido, llegó el comandante de ese grupo paramilitar alias "Tabano" y ordenó que soltaran a Don Ángel pero no sin antes amenazarlo.

No sé, como cosa de mi Dios porque mi Dios es muy grande y la Virgen. Llegó un señor alias "Tábano" y dijo que me soltaran pero que tenía que abandonar ese barrio y Buenaventura.

Ángel Sinisterra, Entrevista 28 de marzo de 2017

Según el informe del Centro Nacional de Memoria Histórica Buenaventura Un Pueblo Sin Comunidad (2015), en el año 2005 se generó un nuevo ciclo de violencia contra la

\footnotetext{
${ }^{24}$ Embarcación pequeña propulsada por motor o a remos para el transporte de personas, encomiendas o pesca. Transporte muy característico en la ciudad de Buenaventura.
} 
población joven, con la masacre de punta del este dejando 12 jóvenes asesinados. Los defensores de derechos humanos se pronunciaron y unen esfuerzos con la iglesia y organizaciones no gubernamentales para frenar este nuevo ciclo de violencia en el puerto lo cual hizo que los grupos armados ilegales tomaran represarías contra los defensores de derechos humanos como con el señor Ángel quien para el año 2005 fue líder sindical y líder comunal en Buenaventura. Para este periodo fueron comunes las amenazas de muerte a defensores de derechos humanos, líderes comunitarios y sindicalistas en muchos casos se materializaron por las FARC y los paramilitares atacaron a quienes consideraron una amenaza para sus intereses.

Como lo menciona la Comisión Colombiana de Juristas (2007), "Persisten los asesinatos y desapariciones forzadas contra defensoras y defensores de derechos humanos: entre julio de 2002 y junio de 2006, por lo menos 52 fueron asesinados o desaparecidos forzadamente (una víctima cada mes en promedio)" (p.11)

En Buenaventura los habitantes del puerto más importante de Colombia han sido víctimas de los grupos criminales que operan en el puerto, presenciando cómo vulneran sus derechos. Alias H.H sembró el terror amenazando en los barrios y calles bonaverences a quien no estuviera de acuerdo con sus acciones delincuenciales, "H.H sostuvo además que para cada grupo de barrios existía un comandante paramilitar en alianza con miembros de bandas de delincuencia común propias de Buenaventura (Versión libre de Hebert Veloza, alias H.H, ante la Fiscalía 17 de la Unidad de Justicia y Paz, marzo 5 de 2008)."25

Fue la zona urbana de Buenaventura donde más se presenció el terror ya ni en sus hogares los habitantes se podían sentir seguros por la constante presencia de los grupos paramilitares quienes vulneraban sus derechos como es el caso del reclutamiento forzado de menores de edad.

Yo tenía un hijo mayor y ellos estaban buscando para incorporar gente para esos grupos y más que todo yo fui militar siempre le inculqué a mi hijo que las cosas malas no se deben hacer mientras tanto ellos se sabían toda la hoja de vida mía... Y porque yo no estaba de acuerdo llegaron y me dijeron "hermano necesitamos que colabore con la causa que su hijo sea parte de nosotros" yo dije que inunca, que lo preferiría muerto...!

Ángel Sinisterra, Entrevista 28 de marzo de 2017

Los grupos paramilitares ejercieron un fuerte control de los barrios de Buenaventura para cometer sus hechos ilícitos y controlar las rutas de narcotráfico en el puerto. Era común ver a los miembros de grupos paramilitares deambular y pasearse por las calles bonaverences sin que el Estado hiciera presencia en este municipio azotado por la violencia desde hace décadas atrás según el Centro Nacional de Memoria Histórica (2015); los barrios de la ciudad portuaria se convirtieron en escenarios de violencia de constantes enfrentamientos entre los grupos al margen de la ley por el control de estos barrios, que dada su ubicación

\footnotetext{
${ }^{25}$ Versión Libre de Hebert Veloza, Alias H.H, ante la Fiscalía 17 de la Unidad de Justicia y Paz, (marzo 5 de 2008).
} 
estratégica facilitan el tráfico de armas y estupefacientes incluso el uso ilícito de minería por parte de los grupos armados ilegales.

El éxito del Bloque Calima se debió además del financiamiento por parte de narcotraficantes de la zona como ya se mencionó en el capítulo anterior, también se debió al involucramiento de exagentes de la fuerza pública y agentes activos de la misma, como también la participación de otros actores como empresarios y comerciantes. A estos partícipes se les conoció como la red de aliados ${ }^{26}$, "Los hombres armados que realizaron la primera incursión salieron desde Tuluá hacia Dagua y Buenaventura el 11 de mayo de 2000. Ese mismo día perpetraron la masacre de Sabaletas. Según el testimonio de H.H esta fue una operación suya en conjunto con Fredy Cadavid alias Luis -teniente retirado del ejército y ex miembro de la inteligencia del Gaula 62 de Cali-, segundo al mando del Bloque en ese momento." 27

Hebert Veloza García alias H.H. reconoció en el diario El País, que los empresarios acudieron a los hermanos Castaño por los constantes hostigamientos de las FARC en el Valle del Cauca y así fue que en el año 2000 llegó a la región el Bloque Calima. ${ }^{28}$ En las versiones libres de justicia y paz, alias H.H. afirmó que una vez los Cataño le asignaron la comandancia del Bloque Calima en reemplazo de David Hernández Rojas alias 39, lo primero que hizo fue buscar financiamiento e incrementar el monto de los aportes con los empresarios de la región. ${ }^{29}$

En el año 2005 el temor de ser asesinado en Buenaventura era muy alto y más aún al ser defensor de derechos humanos y líder social afro:

Uno de ellos pasaba cada momento cerca de mi casa y yo pensaba en cualquier momento me puede matar y después uno de ellos llegó y me dijo: "sabes que la próxima vez te vamos a llevar a las casas de pique a desaparecerte por pedacitos y echarte a los tiburones".

Ángel Sinisterra, Entrevista 28 de marzo de 2017.

Los líderes sociales como el señor Ángel afirmaron que los paramilitares tenían el pretexto de decir que cualquier persona era auxiliadora de las FARC por no estar de acuerdo con su accionar y de esta manera comenzaron a presionarlos y amenazarlos, todo con la finalidad de apoderarse de los negocios ilícitos del puerto que también estaba en disputa con las FARC. Por ejemplo, la ausencia de garantías para quienes lideraban procesos en la

\footnotetext{
${ }^{26}$ Aquellos cooperantes del Bloque Calima que podrían ser de cooperación económica (empresarios, comerciantes, narcotraficantes) y de cooperación militar (exmilitares, militares, integrantes de bandas criminales y excombatientes de las FARC) Centro Nacional de Memoria Histórica-CNMH, Buenaventura: Un Puerto sin Comunidad. (2015), pág. 166.

${ }^{27}$ Centro Nacional de Memoria Histórica-CNMH. (2015). Buenaventura: Un Puerto sin Comunidad, (p.168).

${ }^{28}$ Unidad Investigativa El País, (30 de octubre de 2013). La sangrienta huella del exjefe paramilitar alias H.H. en el Valle del Cauca. El País. Recuperado de: https://www.elpais.com.co/elpais/judicial/noticias/sangrienta-huella-exjefe-paramilitar-alias-hh-valle-cauca

29 Verdadabierta, (08 de agosto de 2018). Bloque Calima, un "depredador" paramilitar marcado por el narcotráfico.Verdadabierta. Recuperado de: https://verdadabierta.com/bloque-calima-depredador-paramilitar-marcado-narcotrafico/
} 
promoción y defensa de los derechos humanos fue una constante. Al respecto, el señor Ángel afirmó que fue presionado por los paramilitares dada su condición de líder social:

Por yo no estar de acuerdo con ellos como soy defensor de derechos humanos no estoy de acuerdo con la violencia y con esos grupos al margen de la ley porque llegaron a los barrios a violar nuestras hijas, a violar las hijas de los vecinos, a mandar, los de las tiendas tenían que pagarles impuestos y tenían que darles de todo, a vivir como un rey, como si ellos fueran dueños de los barrios.

En el periodo del año 2000 al 2005 de acuerdo con el Centro Nacional de Memoria Histórica (2015), los paramilitares al mando de alias H.H en época de elecciones presionaron a la población civil a votar por el ex senador Juan Carlos Martínez donde primero se observa cómo vulneran los derechos de la población al impedir el derecho al sufragio, y segundo una complicidad de políticos con los paramilitares que pone en evidencia la indefensión que se vivía en el puerto donde el Estado no garantiza la protección de los derechos a sus habitantes.

Debido a la falta de presencia de las autoridades estatales, los lugareños tenían una percepción de inseguridad muy alta, en las calles mandaban los paramilitares en las zonas rurales las FARC y eran constantes los enfrentamientos entre paramilitares, FARC y la Armada Nacional, Centro Nacional de Memoria Histórica (2015). Lo anterior hacía que la calidad de vida fuera muy baja por falta de políticas públicas como no contar el principal puerto de Colombia con agua potable, educación de calidad, falta de oportunidades, segregación racial ya era un municipio marginado y olvidado.

De acuerdo al Centro Nacional de Memoria Histórica (2015), en el año 2004 cuando se desmovilizaron los combatientes del Bloque Calima al mando de alias H.H, muchos de los lugareños ni cuenta se dieron dado que la cuestionada desmovilización. Hubo controversia porque los que se desmovilizaron eran una cifra distinta a los registrados en total de dicho bloque y no todos los frentes se desmovilizaron ${ }^{30}$ como es el caso del frente Pacífico ${ }^{31}$ uno de los más despiadados.

Pero el problema de la violencia desmesurada en el puerto estaría lejos de terminar ya que no todos los ex combatientes del Bloque Calima se desmovilizaron. Entre ellos quedarían cuadrillas y grupos armados ilegales que se enfrentarían por el control del puerto para realizar sus actividades relacionadas con minería ilegal, tráfico de armas, extorsiones, tráfico de drogas entre otros delitos. No solo estos reductos paramilitares serían los que aprovecharían la ausencia del Bloque sino también las FARC quienes querían recuperar sus

\footnotetext{
30 Verdadabierta, (08 de agosto de 2018). Bloque Calima, un "depredador" paramilitar marcado por el narcotráfico.Verdadabierta. Recuperado de: https://verdadabierta.com/bloque-calima-depredador-paramilitar-marcado-narcotrafico/

${ }^{31}$ En Valle, Chocó y algunos sectores del Cauca existía el Bloque paramilitar Conjunto Calima-Pacífico, bajo el mando de Diego Murillo Bejarano, alias Don Berna, que estaba conformado por varios frentes, entre ellos el llamado Frente Pacífico o Héroes del Chocó.
} 
territorios. Entonces, empezaría de nuevo la guerra en las calles de Buenaventura por el control de las rutas de narcotráfico estratégicamente ubicadas en los barrios del puerto.

Esta violencia parecía nunca terminar y la población civil no aguantaba más violaciones de sus derechos humanos ya que de nuevo otra época de violencia se vivía en el puerto con distintos protagonistas armados pero con la misma ambición de delinquir. En las calles seguían, las extorsiones, los homicidios, los secuestros, los desplazamientos y las amenazas. Como lo recuerda Don ángel.

Las amenazas fueron personalmente, pasaban en un carro y me decían "hermanito póngase pilas que lo vamos a picar o se va de aqui'”.

Ángel Sinisterra, Entrevista 28 de marzo de 2017.

Los grupos armados ilegales, excombatientes del Bloque Calima y cuadrillas paramilitares que operaban en el sector encrudecieron la violencia al realizar la masacre de Punta del Este en Buenaventura donde murieron 18 jóvenes a manos de estos grupos delincuenciales.

El País, citado por el Centro Nacional de Memoria Histórica (2015, p.189), comenta que esta masacre se caracterizó porque mediante engaños hicieron que se trasladaran los jóvenes a otro lugar para continuar con la práctica de su deporte, sus familiares no sabían dónde estaban y fue entonces cuando encuentran días después sus cuerpos los cuales presentaban quemaduras con ácido y disparos a quema ropa (lo cual indicaría que fueron torturados y luego acribillados). Estos hechos, ocurrieron en Buenaventura luego de la desmovilización reciente del Bloque Calima.

En Buenaventura el conflicto armado persiste, y los actores armados mutan en esta ciudad. Con la expulsión de las FARC por el asedio del Bloque Calima y tras su desmovilización hizo que nuevos grupos paramilitares siguieran delinquiendo, junto con grupos de narcotraficantes, delincuencia común y las FARC que intentaron retornar al casco urbano. Así estuvo Buenaventura hasta que en el año 2010 se creó la banda criminal de La Empresa la cual permaneció delinquiendo hasta el 2012, posteriormente se creó la estructura criminal de Los Urabeños. Como lo mencionan Valencia, Silva y Moreno (2016), "En Buenaventura hay un proceso de expansión de bandas criminales o neoparemilitares, que en ambos casos expresan una apropiación nueva de violencia y unas nuevas formas de control territorial que visibilizan procesos transitorios de re-territorización de la misma..." (p.13).

La violencia en la ciudad de Buenaventura, hizo que muchos de los civiles tuvieron que abandonar sus casas y sitios de trabajo, desplazándose forzosamente para evitar las violaciones a sus derechos humanos por parte de los grupos armados al margen de la ley. Valencia (s.f.), "El desplazamiento forzado perjudica a miles de colombianos, y casi todas las regiones del país son expulsoras y receptoras de estas personas. Las condiciones de vida de los desplazados son de pobreza absoluta..." (p.233).

Es por ello, que "el desplazamiento forzado fue la modalidad de violencia que mayor cantidad de víctimas generó en Buenaventura entre 1990 y 2014, ya que expulsó a la fuerza 
y directamente a dos de cada cinco bonaverenses..." (Centro Nacional de Memoria Histórica, 2015, p.238).

Si bien muchos de los desplazados de Buenaventura ya vivían en condiciones difíciles al desplazarse a otras ciudades y municipios de Colombia su situación estaba lejos de mejorar y por el contrario antes empeoraba dado que muchos llegaban era a buscar empleos, a pedir ayuda a las autoridades, incluso a mendigar en las calles y semáforos. Muchos continuaron padeciendo necesidades todo ello para escapar a la violencia pero seguían abandonados por el Estado.

En el año 2007, el señor Ángel Sinisterra se vio en la obligación de huir por las amenazas recibidas contra su vida e integridad y contra la de sus familiares. Estas amenazas fueron por parte de los paramilitares. Como se mencionó anteriormente fueron personalmente y en reiteradas ocasiones en la calle, y hasta en la puerta de su propia casa. Don Ángel decidió escapar de la violencia junto con algunos de sus familiares hacia Ibagué, Tolima porque ya conocía esta ciudad, tenía amigos y le pareció una ciudad muy tranquila para vivir.

No, pues llegué normalmente, al barrio las Américas de Ibagué. En el año 2007, como ya conocía tenía varios amigos, pero aquí prácticamente ha sido pasando las mismas necesidades. Ha sido duro para la labor, para las ayudas que da el gobierno, para las víctimas y todo eso, en un barrio marginado un asentamiento llamado Milagro de Dios como decimos nosotros "una invasión”. Le hacen falta todos los servicios públicos.

Ángel Sinisterra, Entrevista 28 de marzo de 2017.

El señor Ángel vivió en la ciudad de Ibagué del año 2007 hasta el año 2011. En el mes de enero de 2011, Don Ángel tuvo que ver partir a muchos de sus familiares a otras ciudades buscando mejores condiciones de vida ya que él se encontraba desempleado y padeciendo necesidades en el humilde barrio ibaguereño llamado Milagro de Dios. Entonces fue en el año 2011 cuando decidió volver a su natal Buenaventura, porque extrañaba su tierra, su comida, sus amigos y algunos pocos familiares que aún vivían allí.

Tras volver a Buenaventura en el año 2011 Don Ángel y unos pocos familiares se ubicaron en la ciudad puerto hasta el 2013. En este año el señor Ángel y su hermano fueron a reclamar unas tierras que eran de su señor padre en la vereda La Gloria zona rural de Buenaventura. Antes de llegar a su destino, fueron interceptados por un sujeto quien les informó que las tierras que estaban buscando eran de Los Urabeños y en un tono desafiante les dijo que allá en la vereda La Gloria los estaban esperando para hablar. El señor Ángel y su hermano decidieron devolverse a su casa por temor a ser asesinados. Al día siguiente, fueron unos sujetos hasta la casa de Don Ángel en donde se identificaron como miembros de pertenecer a Los Urabeños y le informaron junto a su hermano que debían abandonar Buenaventura o que debían "atenerse" a las consecuencias.

Cuando llegamos allá a Buenaventura que ya estando ubicados, mi papá había dejado unas tierras en la vereda La Gloria. Cuando fuimos con mi hermano a reclamar eso, tuvimos la sorpresa que eso estaba invadido por un grupo que opera en estos momentos en 
Buenaventura Los Urabeños que son del golfo. Pues es un sector predilecto para ellos, para sus cultivos y para sus negocios ilícitos. A raíz de eso ellos fueron a la casa me amenazan y me dijeron que tenía que abandonar Buenaventura y fue entonces que volví a Ibagué en el 2013 por el desplazamiento y amenazas y ya hice la denuncia que reposa en la fiscalía de Buenaventura.

Ángel Sinisterra, Entrevista 28 de marzo de 2017

Don Ángel se desplazó a Ibagué en el año 2013 luego de las amenazas de Los Urabeños. Se radicó definitivamente en esta ciudad, donde continúo con su labor de líder social afrocolombiano y fue elegido por varias personas de la comunidad afrodescendiente desplazadas para que las representara en las mesas de víctimas. En el año 2016, fue amenazado personalmente por personas que se presentaron como integrantes del grupo ELN y recibió amenazas por medio de panfletos y llamadas telefónicas de las FARC y de las AGC. En muchos casos, como el de Don Ángel las amenazas por las actividades de liderazgo no cesan.

En Diciembre de 2016, estando en una finca avenida carrizales que queda en El Salado [Barrio al norte de la ciudad de Ibagué Tolima]. Llegaron dos tipos con traje negro y con pasamontañas y me amenazaron que tenía que irme de Ibagué y todo eso porque aquí nosotros los afro y los étnicos no tenemos derecho a nada, ni a respirar. Que ellos no estaban de acuerdo con la paz, se identificaron como miembros del ELN. También recibí amenazas por trabajar con la mesa de víctimas del frente 21 de las FARC y por los Gaitanistas.

Ángel Sinisterra, Entrevista 28 de marzo de 2017.

El señor Ángel Sinisterra continuó con su labor de líder afro defensor de derechos humanos en la ciudad de Ibagué, pese a las amenazas recibidas. Su labor como líder social afro y defensor de derechos humanos en la mesa de victimas municipal y departamental se ha tornado peligrosa por las amenazas que recibe. Según la Oficina del Alto Comisionado de las Naciones Unidas (2017), actualmente el país afronta una situación que es grave por los asesinatos y hostigamientos contra los líderes y defensores de derechos humanos. Tanto así, que la Oficina en Colombia del Alto Comisionado de las Naciones Unidas observa con profunda preocupación la serie de asesinatos a defensores de derechos humanos en el territorio nacional y rechazó el comportamiento de algunos de los funcionarios públicos que se abstienen de reconocer la delicada situación que afrontan los defensores de derechos humanos.

Sinisterra Viveros también afronta necesidades económicas junto con su familia. Pero pese a los problemas, el señor Ángel continuó realizando esfuerzos para promover los derechos de su comunidad. A través de su propia asociación, la asociación afro víctima del conflicto del Tolima (ASFROVICTOL), con la que trabaja todos los días escuchando las necesidades de los afros y como él lo dice luchando contra las injusticias, para que los miembros de la comunidad que representa tengan una mejor calidad de vida en esta ciudad. Pese a las 
amenazas de las que ha sido objeto el señor Ángel persiste en la reivindicación de derechos de derechos individuales y colectivos.

\section{Línea de Tiempo de los Hechos}

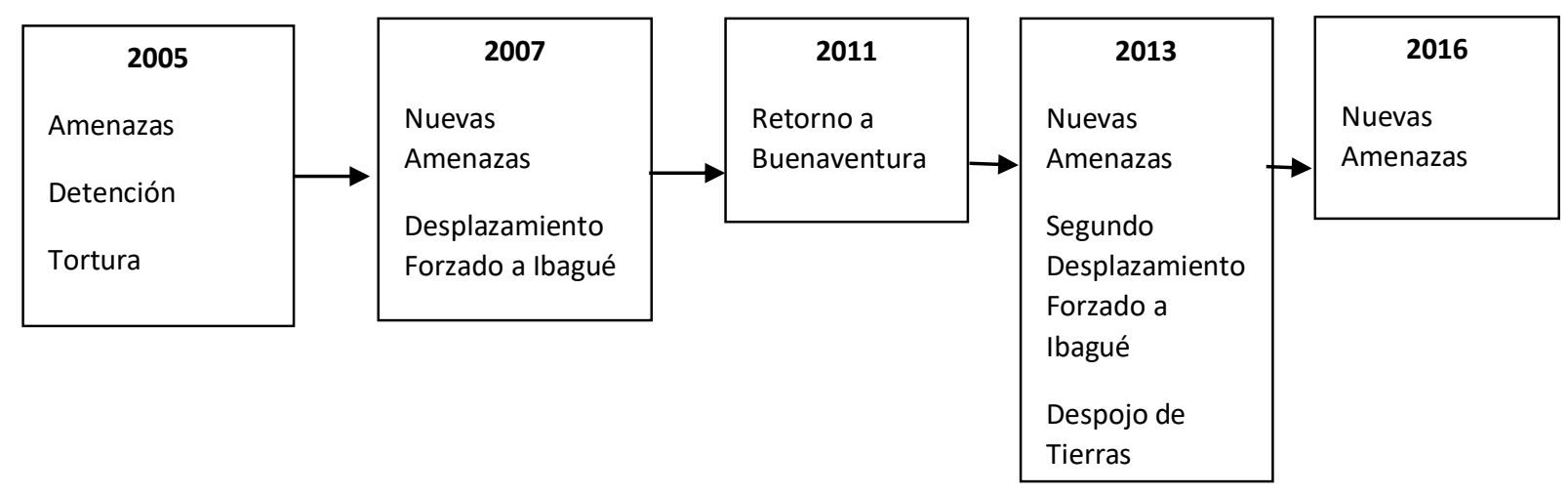

Gráfico 6. Millán E. (2019). Gráfico. Elaboración propia. 


\section{CAPÍTULO III}

\section{MARCO JURÍDICO}

Este acápite tiene como objeto analizar los derechos que fueron vulnerados a Don Angel. Para ello, se tendrán en cuenta el marco jurídico internacional y las normas nacionales. El siguiente estudio, consiste en definir cada hecho victimizante a la luz de los instrumentos internacionales y nacionales de protección de derechos humanos para posteriormente determinar si los hechos de tortura, desplazamiento forzado y amenazas padecidos por el señor Ángel Sinisterra reúnen los elementos que constituyen un crimen internacional. Los hechos bajo exámen, son los padecidos en los municipios de Buenaventura e Ibagué entre el año 2005 al 2016, cuyos presuntos responsables son diferentes grupos armados al margen de la ley.

Dada la complegidad de la investigación a continuación se analizarán a continuación el marco normativo y jurisprudencial a nivel nacional e internacional ${ }^{32}$. Dentro de las fuentes examinadas se acudió a distintos instrumentos nacionales e internacionales, jurisprudencia, normas, reglas y principios del soft law (de este último por ejemplo, los Principios Rectores de los Desplazados Internos y demás documentos expedidos por la ONU) a fin de ampliar los conceptos de los diferentes crímenes expuestos en el caso concreto.

\subsection{Responsabilidad Internacional del Estado por Hechos de Terceros}

Teniendo en cuenta que Don Ángel fue víctima de hechos que se produjeron en el conflicto armado interno colombiano, cuyos presuntos responsables en su mayoría fueron grupos paramilitares, posiblemente existió aquiescencia con agentes estatales. Es menester analizar la posible responsabilidad del Estado por hechos internacionalmente ilícitos.

Cabe resaltar que el derecho internacional de los derechos humanos no tiene como objeto juzgar a los particulares o terceros que violan derechos humanos, sino de amparar a las víctimas de manera complementaria. ${ }^{33}$ Son los Estados quienes deben juzgar y sancionar a los responsables de las violaciones de los derechos humanos.

Según la resolución 56/83 de la ONU, hay un hecho internacionalmente ilícito del Estado cuando su comportamiento consiste en una acción u omisión y esta es atribuible al Estado según el derecho internacional y también constituye una violación a una obligación internacional de ese Estado. Pueden cometer este hecho internacionalmente ilícito cualquier

\footnotetext{
${ }^{32}$ Se destaca que los instrumentos analizados en este apartado son de obligatorio cumplimiento para Colombia dada su integración normativa bajo un solo núcleo a través del Bloque de Constitucionalidad.

${ }^{33}$ Corte Interamericana de Derechos Humanos. Caso Velásquez Rodríguez vs Honduras. Fondo. Sentencia del 29 de julio de 1988. Serie Con. 4, párr.134.
} 
órgano del Estado, personas que ejerzan atribuciones del poder público y movimientos de insurrección. ${ }^{34}$

Ahora bien, no todas las violaciones de derechos humanos cometidas entre particulares son responsabilidad de los Estados. La Convención Interamericana de Derechos Humanos (CIDH), en su artículo 1.1 establece si una violación de derechos humanos es atribuible a los Estados parte, obligando así a los Estados al cumplimiento de los deberes fundamentales de respeto ${ }^{35}$ y garantía. ${ }^{36}$ Además establece que:

Todo menoscabo a los derechos humanos reconocidos en la Convención que pueda ser atribuido, según las reglas del Derecho internacional, a la acción u omisión de cualquier autoridad pública, constituye un hecho imputable al Estado que compromete su responsabilidad en los términos previstos por la misma Convención. ${ }^{37}$ (Corte Interamericana de Derechos Humanos. Caso Velásquez Rodríguez vs Honduras, 29 de julio de 1988).

Así las cosas, se estaría ante una responsabilidad internacional directa la cual es atribuible únicamente a los agentes estatales. Pero según Medina (s.f.), la responsabilidad internacional del Estado por actos de terceros en un principio no pueden ser atribuible al Estado por no ser perpetrada por sus agentes estatales; no obstante, el carácter erga omnes ${ }^{38}$ de las obligaciones de garantía y respeto de derechos humanos ocasionan una responsabilidad en un sentido más amplio que cubre no sólo relaciones entre Estado y sus agentes estatales, sino también alcanza a los particulares mediante una responsabilidad internacional indirecta. Con base en lo anterior, los Estados adquieren una obligación positiva de garantizar los derechos humanos en relaciones interindividuales realizando todo lo que esté a su alcance para prevenir las violaciones de derechos humanos entre sus nacionales. ${ }^{39}$

Esta situación también la resalta la Corte en la sentencia del caso de Mapiripán vs Colombia:

\footnotetext{
${ }^{34}$ Asamblea General de las Naciones Unidas. Responsabilidad del Estado por Hechos Internacionalmente Ilícitos. Resolución No. 56/83 del 25/06/2010.

35 Medina Ardila, F. (s.f) La Responsabilidad Internacional del Estado por actos de particulares: análisis jurisprudencial interamericano. Obligación de Respetar: Los estados deben proteger los derechos y libertades de la convención americana y el poder público tiene unos límites que surgen de los derechos humanos inherentes a las personas.

36 Medina Ardila, F. (s.f) La Responsabilidad Internacional del Estado por actos de particulares: análisis jurisprudencial interamericano. Obligación de Garantía: Los Estados parte deben proveer los medios para el ejercicio de los derechos humanos y deben investigar, juzgar y sancionar las violaciones de derechos humanos.

${ }^{37}$ Corte Interamericana de Derechos Humanos. Caso Velásquez Rodríguez vs Honduras. Fondo. Sentencia del 29 de julio de 1988- Serie C No. 4, párr. 164, 169 y 170.

${ }^{38}$ Locución latina que significa frente a todos. Es un efecto el cual expresa que un tratado o un derecho relaciona a todas las partes.

${ }^{39}$ Medina Ardila, F. (s.f) La Responsabilidad Internacional del Estado por actos de particulares: análisis jurisprudencial interamericano. (p.16). doi: r26724.pdf
} 
La responsabilidad estatal bajo la Convención Americana sólo puede ser exigida a nivel internacional después de que el Estado haya tenido la oportunidad de repararlo por sus propios medios, y la atribución de la misma a un Estado por actos de agentes estatales o de particulares deberá determinarse atendiendo a las particularidades y circunstancias de cada caso. $^{40}$ (Corte Interamericana de Derechos Humanos. Caso Mapiripán vs Colombia, septiembre de 2005).

Para Medina (s.f.), la Corte estableció cuales son los actos por los cuales se puede atribuir la responsabilidad internacional a terceros en dos escenarios. El primero, es por aquiescencia de agentes estatales con particulares ${ }^{41}$, y el segundo, es por negligencia del Estado para prever las violaciones entre particulares. ${ }^{42}$

Respecto al caso sub júdice fueron los grupos paramilitares quienes torturaron, desplazaron forzadamente y realizaron algunas de las amenazas de atentar contra Ángel Sinisterra. Estos hechos sucedieron bajo un contexto del conflicto armado interno en Buenaventura y donde era común la aquiescencia de agentes estatales con los grupos paramilitares que operaron en el municipio de Buenaventura.

\section{La Tortura}

En el presente apartado se usaron instrumentos nacionales e internacionales y jurisprudencia con la finalidad de ampliar el concepto de tortura, elementos que se analizan para su correspondiente adecuación del caso concreto.

\subsection{Normas y Estándares Internacionales de Derechos Humanos sobre Tortura}

En el artículo 1 de la convención contra la tortura y otros tratos o penas crueles, inhumanos o degradantes de la ONU define la tortura como todo acto intencional que ocasione a una persona dolores y sufrimientos graves ya sean físicos o mentales con la finalidad de obtener de ella o de un tercero información o confesión, para castigarla, obligarla, intimidarla o por cualquier motivo basado en cualquier tipo de discriminación, puede ser cometida por funcionario público, por un tercero o en aquiescencia de estos. ${ }^{43}$

\footnotetext{
${ }^{40}$ Corte Interamericana de Derechos Humanos. Caso Mapiripán vs Colombia. Fondo. Reparaciones y Costas. Sentencia del 15 de septiembre de 2005- Serie C No. 4, párr. 113.

${ }^{41}$ La corte interamericana de derechos humanos preciso este primer escenario en los casos hondureños de: Velásquez Rodríguez vs Honduras. Fondo. Sentencia del 29 de julio de 1988. Serie C No. 4, párr. 173; Caso Godínez Cruz vs Honduras. Fondo. Sentencia del 20 de enero de 1989. Serie C no. 5, párr. 183 y 187. Caso Fairén Garbi y Solís Corrales vs Honduras. Fondo. Sentencia del 15 de marzo de 1989. Serie C No. 6, párr. 152 y 161.

42 Medina Ardila, F. (s.f) La Responsabilidad Internacional del Estado por actos de particulares: análisis jurisprudencial interamericano. (p.19). doi: http://www.corteidh.or.cr/tablas/r26724.pdf

${ }^{43}$ Asamblea General. convención contra la tortura y otros tratos o penas crueles del 10 de diciembre de 1984, articulo 1.
} 
Este concepto de tortura es muy similar al que presenta la Convención Interamericana para Prevenir y Sancionar la Tortura de 1987 en su artículo 2, pero le agrega que "se entenderá también como tortura la aplicación sobre una persona de métodos tendientes a anular la personalidad de la víctima o a disminuir su capacidad física o mental, aunque no causen dolor físico o angustia psíquica (...)"44

La Corte Interamericana de Derechos Humanos además afirma que los elementos que constituyen la tortura son: a) un acto intencional, b) que este acto intencional causa severos sufrimientos físicos o mentales y c) que se cometa con un determinado fin o propósito ${ }^{45}$.

La CIDH en el caso Tibi vs Ecuador, expuso lo siguiente frente a la concepción de tortura "pueden calificarse como torturas física y psíquica, aquellos actos que han sido preparados y realizados deliberadamente contra la víctima para suprimir su resistencia psíquica y forzarla a autoinculparse o a confesar determinadas conductas". ${ }^{46}$

Así mismo para determinar la tortura se debe resaltar según la $\mathrm{CIDH}$ en el caso Penal Miguel Castro Castro vs Perú, que se debe tener en cuenta todas las circunstancias del caso tales como "la duración de los tratos, sus efectos físicos y mentales (...)" Estos últimos efectos los mentales al respecto la Corte afirmó lo que los actos que produzcan en la víctima un sufrimiento psíquico o moral agudo también son considerados tortura. ${ }^{47}$

La Corte en el caso Cantoral Benavidez vs Perú citando ${ }^{48}$ a su vez a la Corte Europea de Derechos Humanos, define la noción de tortura psicológica como el mero peligro de que se vaya a cometerse un acto de tortura y con eso basta para considerarla como tortura psicológica, pero este peligro debe ser real y coherente. ${ }^{49}$ También la Corte Interamericana de Derechos Humanos define la tortura psicológica en los casos de Maritza Urrutia vs Guatemala $^{50}$ y Familia Barrios vs Venezuela" ${ }^{51}$, como "las amenazas y el peligro real de someter a una persona a lesiones físicas, produce, en determinadas circunstancias, una angustia moral de tal grado que puede ser considerada como tortura psicológica".

\footnotetext{
${ }^{44}$ Convención Interamericana para Prevenir y Sancionar la Tortura del 28 de febrero de 1987, articulo 2.

${ }^{45}$ Corte Interamericana de Derechos Humanos. Caso Bueno Alves vs Argentina. Fondo. Reparaciones y Costas. Sentencia del 11 de mayo de 2007, párr. 79.

${ }^{46}$ Corte Interamericana de Derechos Humanos. Caso Tibi vs Ecuador. Excepciones preliminares, fondo, reparaciones y costas. Sentencia del 07 de septiembre de 2004, párr. 146.

${ }^{47}$ Corte Interamericana de Derechos Humanos. Caso Fernández Ortega y Otros vs México. Fondo, Reparaciones y Costas. Sentencia del 30 de agosto de 2010, párr.124.

${ }^{48}$ Corte Interamericana de Derechos Humanos. Caso Cantoral Benavidez vs Perú. Fondo. Sentencia del 18 de agosto de 2000, párr. 120.

${ }^{49}$ Convenio Europeo de Derechos Humanos, articulo 3. Prohibición de la Tortura.

${ }^{50}$ Corte Interamericana de Derechos Humanos. Caso Maritza Urrutia vs Guatemala. Fondo, Reparaciones y Costas. Sentencia del 27 de noviembre de 2003, párr. 92.

${ }^{51}$ Corte Interamericana de Derechos Humanos. Caso Familia Barrios vs Venezuela. Fondo, Reparaciones y Costas. Sentencia del 24 de noviembre de 2011, párr.51.
} 
Según Nash Rojas (2009), la tortura no se permite bajo ninguna circunstancia, ningún Estado puede permitir la tortura en su jurisdicción, ni bajo el alegato de encontrarse en un estado de excepción. Esta prohibición a la tortura es una norma absoluta considerada dentro de la categoría más alta dentro de las normas internacionales de derecho internacional por su carácter de Jus Cogens ${ }^{52}$ o norma de imperativo cumplimiento. ${ }^{53}$

Amnistía Internacional (s.f.), "La noción tradicional y más extendida de tortura se ha centrado en el dolor y sufrimiento infligidos a una persona (...)".54 Desde el año 1948 cuando se creó la declaración Universal de los Derechos Humanos la tortura y todas las formas de crueldad y también de humillación fueron prohibidas a nivel mundial, dicha prohibición es vinculante para aquellos Estados que no han ratificado tratados de derechos humanos que prohíban la tortura. ${ }^{55}$

\section{Análisis Concreto del Caso}

\subsubsection{La Tortura Física}

Se produjo cuando Don Ángel fue atado de pies y manos, puesto a la intemperie sobre una lancha, los perpetradores además se turnaron para propinarle puños, bofetadas y puntapiés en su cara y cuerpo, durante dos días. Al señor Ángel en esos dos días no se le suministró agua ni alimentos.

\subsubsection{La Tortura Psicológica}

Se presentó cuando el taxi que transportaba a Don Ángel ingresó a los barrios controlados por los paramilitares, desde ese momento Don Ángel entró en angustia y empezó a temer por su vida e integridad.

Una vez fue puesto sobre la lancha recibió toda clase de insultos y también amenazas de cómo sería asesinado él y su familia por parte de los paramilitares.

Estos hechos pueden ser considerados como tortura psicológica porque para la Corte Interamericana de Derechos Humanos basta con el solo sentimiento de angustia moral de una persona por enterarse que puede ser torturado o sometido a tratos crueles, para que se puedan constituir estos hechos como tortura psicología. Claro está que este temor debe ser real y coherente. Lo anterior lo expone la Corte en los siguientes casos; Cantoral Benavidez vs Perú (2000), Maritza Urrutia vs Guatemala (2003), Familia Barrios vs Venezuela (2011), J. vs Perú (2013) y Espinoza González vs Perú (2014).

\footnotetext{
${ }^{52}$ Locución latina que se emplea en el derecho internacional para indicar que una norma o tratado es de obligatorio cumplimiento o tiene este efecto. También escrito "ius cogens".

${ }^{53}$ Nash, R. Alcance del Concepto de Tortura y Otros Tratos Crueles, Inhumanos y Degradantes. Anuario de derecho constitucional latinoamericano, versión (XV), (P.4), doi: r23545.pdf

${ }^{54}$ Amnistía Internacional. (s.f.). En Que Estamos, Tortura. Recuperado de https://www.es.amnesty.org/em-que-estamos/temas/tortura/

${ }^{55}$ Amnistía Internacional. (s.f.). En Que Estamos, Tortura. Recuperado de https://www.es.amnesty.org/em-que-estamos/temas/tortura/
} 
La tortura está prohíbida y penada en el ordenamiento jurídico colombiano, en su constitución y en su código penal. Pese a lo anterior el señor Ángel Sinisterra es torturado con ocasión al conflicto armado colombiano vulnerándosele normas nacionales e internacionales encaminadas a prevenir y sancionar la tortura.

La Corte en el caso de Penal Miguel Castro Castro vs Perú (2006), aduce que las torturas físicas o mentales son actos preparados y tienen una intensión, coincide también a esta noción el CICR (2005). Según lo anterior el señor Ángel fue torturado conforme a lo establecido por el derecho internacional humanitario y la Corte Interamericana de Derechos Humanos, porque en el caso concreto el comando paramilitar planeó la tortura contra el señor Ángel al engañarlo para que se subiera al taxi, luego fue trasladado a la zona de bajamar donde procedieron a torturarlo física y psicológicamente. Los perpetradores tienen la intención primero de imponerle un castigo a Don Ángel en represaría por su ya conocida labor de líder social en la zona y segundo cobran especial relevancia las amenazas de los paramilitares cuando le manifestaron al señor Ángel que lo asesinarían a él y a su familia, lo que le ocasionó una angustia moral.

En el caso sub judice se deben tener en cuenta todas las circunstancias para analizar la gravedad de los actos que puedan constituir tortura como lo expresa la Corte Interamericana de Derechos Humanos a través del caso Penal Miguel Castro Castro vs Perú, “(...) es preciso ponderar todas las circunstancias del caso tales como la duración de los tratos, sus efectos físicos y mentales (...). ${ }^{, 56}$ El señor Ángel fue víctima de tortura física y psicológica a la luz de la Corte Interamericana de Derechos Humanos y según el caso anterior.

\subsection{Marco Jurídico Nacional}

La Corte Constitucional mediante la sentencia C-587 de $1992{ }^{57}$ fue la primera en establecer el alcance de la prohibición de la tortura en el ordenamiento interno (Aníbal \& Ruiz, 2011 $)^{58}$. Respecto a que la tortura no es propia del Estado sino que los particulares tambien pueden cometerla. A su vez la Corte en la Sentencia T 045 de 1995 señala un concepto de tortura más específico:

La tortura, a grosso modo, es un medio indebido -pues atenta contra la dignidad humana- para la obtención de diversos resultados, tales como informaciones, castigos o coacciones, basado en el uso de métodos que, por producir grave dolor o

\footnotetext{
${ }^{56}$ Corte Interamericana de Derechos Humanos. Caso Castro Castro vs Perú. Fondo, Reparaciones y Costas. Sentencia del 25 de noviembre de 2006, párr.316.

${ }^{57}$ Corte Constitucional. Sentencia del 12 de noviembre de 1992. Magistrado Ponente Ciro Angarita Baron. Alcance de la Tortura.

58 Aníbal, D., Ruiz, G. (2011). El Delito de la Tortura en la Legislación Colombiana y su contraste con la normatividad internacional. [p.203]. doi: https://revistas.unisimon.edu.co/index.php/justicia/article/download/907/895
} 
aflicción en las víctimas, por lo común someten sus voluntades a la del torturador (Sentencia T 045/95, p.6). ${ }^{59}$

\subsubsection{Derecho Constitucional}

En la Constitución Política de Colombia de 1991, el artículo 12. Señala "Nadie será sometido a tortura. ${ }^{60}$

\subsubsection{Derecho Penal}

En el Código Penal Colombiano Ley 599 de 2000, consagra en el artículo 137. Tortura en Persona Protegida, "El que, con ocasión y en desarrollo de conflicto armado, inflija a una persona dolores o sufrimientos, físicos o psíquicos, con el fin de obtener de ella o de un tercero información o confesión, de castigarla por un acto por ella cometido o que se sospeche que ha cometido, o de intimidarla o coaccionarla por cualquier razón que comporte algún tipo de discriminación, incurrirá en (...)".

El señor Luis Ángel Sinisterra fue llevado a los barrios de bajamar del municipio de Buenaventura, por un grupo de paramilitares que operaban en ese sector, los cuales proceden a torturarlo física y psicológicamente, lanzándole con insultos y amenazas de ser asesinado y de atentar contra su familia, durante 48 horas. Siendo víctima del delito de tortura el cual está contemplado como prohibición en el ordenamiento jurídico colombiano.

\subsection{Marco Jurídico Internacional}

La tortura en diferentes instrumentos internacionales se encuentra contemplada como crimen que atenta contra los derechos humanos. Los Estados deben prohibir y sancionar toda forma de tortura, tratos crueles e inhumanos o degradantes.

\subsubsection{Derecho Internacional de Derechos Humanos}

Tanto en el Sistema Interamericano de Derechos Humanos como en el Sistema Universal de Derechos Humanos. Ya sea por medio de Convenciones o Pactos buscan el cumplimiento de las obligaciones que adquieren los Estados parte para erradicar toda forma de tortura, sean penas, tratos degradantes, crueles o inhumanos que atentan contra los derechos humanos de las personas.

\subsubsection{Sistemas de Protección de Derechos Humanos}

Sistema Universal de Derechos Humanos

\footnotetext{
${ }^{59}$ Corte Constitucional de Colombia. Sentencia T 045/95, p.6.

${ }^{60}$ Constitución Política de Colombia de 1991, artículo 12. Tortura en Persona Protegida.
} 
Como se mencionó en el capítulo anterior, Don Ángel al ser lesionado se le vulneraron los siguientes instrumentos internacionales que prohíben la tortura como: El Pacto Internacional de Derechos Civiles y Políticos de 1966, en el artículo 7. Según el cual "Nadie será sometido a torturas o tratos crueles, inhumanos y degradantes." Se afirma, que fueron tratos crueles porque el señor Ángel fue puesto en estado de indefensión cuando es atado de pies y manos, luego puesto a la intemperie y sin recibir agua ni alimentos durante dos días.

De igual forma, la Declaración sobre la protección de todas las personas contra la tortura y otros tratos o penas crueles, inhumanos o degradantes de la Asamblea General No 3452 del 9 de diciembre de 1975: 1.1. "A los efectos de la presente Declaración, se entenderá por tortura todo acto por el cual un funcionario público, u otra persona a instigación suya, inflija intencionalmente a una persona penas o sufrimientos graves, ya sean físicos o mentales (...)". Se recuerda, que Don Ángel fue torturado por las AUC por ser miembro del sindicato de trabajadores del puerto de Buenaventura y por ser líder social que se opuso a las acciones de las AUC.

Así mismo, Don Ángel fue sometido por los paramilitares a un trato indignante al ser golpeado, atado y privado de su libertad, tal como lo indica el artículo 1.2 de esta declaración "La tortura constituye una forma agravada y deliberada de trato o pena cruel, inhumano o degradante."

La Declaración señalada en su artículo 2 indica que "Todo acto de tortura u otro trato o pena cruel, inhumano o degradante constituye una ofensa a la dignidad humana y será condenado como violación de los propósitos de la Carta de las Naciones Unidas y de los derechos humanos y libertades fundamentales proclamados en la Declaración Universal de Derechos Humanos."

En el caso de señor Ángel, al ser torturado se prevé que los hechos se constituyen como una clara violación a la Carta de las Naciones Unidas y a la Declaración Universal de los derechos humanos.

Don Ángel fue torturado física y psicológicamente en razón del conflicto armado interno por un grupo de personas que se identificaron como paramilitares y el hecho se produjo en una zona de débil presencia del Estado, lo cual no exime de responsabilidad a las autoridades estatales que debían velar por proteger los derechos de Don Ángel. Como lo indica el artículo 3 de la presente convención "Ningún Estado permitirá o tolerará tortura u otros tratos o penas crueles, inhumanos o degradantes. No podrán invocarse circunstancias excepcionales tales como estado de guerra o amenaza de guerra, inestabilidad política interna o cualquier otra emergencia pública como justificación de la tortura u otros tratos o penas crueles, inhumanos o degradantes."

Igualmente, la Convención contra la tortura y otros tratos o penas crueles, inhumanas o degradantes de 1984 en sus artículos señalan: 
Artículo primero, "todo acto por el cual se inflija intencionadamente a una persona dolores o sufrimientos graves, ya sean físicos o mentales (...)”. Don Ángel tuvo que soportar dolores físicos y mentales al ser golpeado, atado de pies y manos, y puesto a la intemperie, como también lo insultaron y le manifestaron que lo iban a asesinar a él y a su familia. Este artículo además afirma el objeto de la tortura, el cual para el caso del señor Ángel, el grupo paramilitar le infligió la tortura con el fin de castigarlo, obtener información y lograr intimidarlo para evitar que Don Ángel continuara incitando a los lugareños a defenderse y de este modo obstaculizar sus operaciones ilícitas en la zona.

Las autoridades locales como la fiscalía y la personería pese a tener conocimiento a través de las denuncias hechas por Don Ángel sobre extorsiones a comerciantes, amenazas de reclutamiento de menores de edad y amenazas y conocer también el contexto de violencia de los barrios de Buenaventura, no se tomaron las medidas eficaces que impidieran la comisión de hechos delictivos en la zona como el caso de tortura a Don Ángel ya que fue llevado a zonas de dominio paramilitar dentro de la ciudad puerto, pese a lo estipulado por el artículo 2.1, el cual menciona que todo Estado parte tomará medidas más adecuadas que garanticen la no comisión de actos de tortura dentro de su jurisdicción.

Por otro lado, El artículo 2.2, de la misma Convención no exime de responsabilidad al Estado bajo ningún contexto "tales como estado de guerra o amenaza de guerra, inestabilidad política interna o cualquier otra emergencia pública como justificación de la tortura". De lo anterior, se afirma que el Estado debía actuar garantizando las medidas más adecuadas y eficaces para impedir actos de tortura, aún más en una ciudad como Buenaventura que estaba bajo un contexto de conflicto armado interno.

\section{Sistema Interamericano de Derechos Humanos}

También cuando fue el señor Ángel torturado se le sometió a tratos degradantes y crueles durante su detención mientras duró la tortura. En el sistema interamericano de derechos humanos se establece la prohibición de someter a torturas, penas o tratos crueles, inhumanos o degradantes y se establece que toda persona privada de la libertad debe ser tratada con respeto (artículo 5.2. de La Convención Americana sobre Derechos Humanos de 1969).

Las autoridades del Estado colombiano no cumplieron con las obligaciones de prevenir y sancionar la tortura de la cual fue víctima Don Ángel Sinisterra, debido a que las autoridades conocían el contexto histórico de violencia en la zona, como la presencia de grupos al margen de la ley es decir paramilitares y guerrilleros de las FARC, sus hostigamientos a la población civil, las prácticas de torturas, como las casas de pique y no ejecutaron medidas eficaces para prevenir los actos de tortura desconociendo de esta manera la obligación de prevenir y sancionar la tortura. Además Don Ángel ya era conocido como un líder social que convocaba a los lugareños a no callar ante los hostigamientos de los grupos armados al margen de la ley y también hizo denuncias ante autoridades locales sobre la violencia en los barrios principalmente los de bajamar de la 
ciudad portuaria. (Artículo 1 de La Convención Interamericana para Prevenir y Sancionar la Tortura de 1985).

La cuadrilla paramilitar que operó en Buenaventura obró con la intención de torturar al señor Ángel causándole daños físicos y psicológicos, asimismo el señor Ángel fue sujetado con cuerdas y dejándolo a la intemperie durante un día, lo cual según el artículo 2 de Convención Interamericana para Prevenir y Sancionar la Tortura de 1985, produjo una disminución de la capacidad física y mental en Don Ángel.

\subsubsection{Derecho Internacional Humanitario}

La concepción de tortura para el Derecho Internacional Humanitario es una un poco distinta pero sin alejarse a la noción de la Convención contra la tortura y otros tratos o penas crueles de las naciones unidas. Esto se debe a que no requiere la participación de una persona en ejercicio de sus funciones públicas para que los tratos destinados a infligir dolores o sufrimientos sean considerados como tortura, la tortura debe contener la existencia de un propósito concreto, como obtener información o imponer un castigo. En este aspeco, el Comité Internacional de la Cruz Roja (CICR) utiliza la expresión "malos tratos" para referirse a tortura y otros métodos abusivos prohibidos por el derecho internacional, incluidos los tratos inhumanos, crueles humillantes y degradantes, los ultrajes a la dignidad personal y la coerción física y moral. ${ }^{61}$

\section{Caso Concreto}

Ángel Sinisterra fue víctima de tortura según el derecho internacional humanitario, puesto que fue torturado por los paramilitares que operaron en la ciudad portuaria en el año 2005 . El derecho internacional afirma que el torturador debe tener un motivo para realizar la tortura, el grupo paramilitar torturó a Don Ángel por ser un líder social que se opuso a las intenciones y planes de los paramilitares en Buenaventura. Además Sinisterra Viveros fue sometido a tratos crueles como lo afirma el Comité Internacional de la Cruz. Don Ángel fue cruelmente atado de pies y manos, puesto a la intemperie durante más de 48 horas en donde los abusadores se turnaron para propinarle puntapiés y puñetazos en todo su cuerpo y le dijeron que sería asesinado junto con su familia.

Los hechos de tortura física y psicológica en contra el señor Ángel Sinisterra, se produjeron en el marco del conflicto armado interno colombiano. Por lo cual es competente el artículo 3 común a los Convenios de Ginebra de 1949 al ser el conflicto armado de carácter no internacional. También, es aplicable al caso sub judice el Protocolo II adicional a los Convenios de Ginebra de 1949 relativo a la protección de las víctimas de los conflictos armados sin carácter internacional de 1977, por ser un conflicto armado interno y porque las partes beligerantes son las fuerzas armadas de Colombia, las fuerzas armadas disidentes

${ }_{61}$ Comité Internacional de la Cruz Roja (CICR). (2005). ¿Qué se entiende por tortura y malos tratos? Recuperado de https://www.icrc.org./es/doc/resources/documents/misc/69tjvk.htm 
y los grupos armados organizados y estos grupos armados al margen de la ley ejercen control territorial en la zona de Buenaventura Valle del Cauca, realizando operaciones militares continuas y permanentes. ${ }^{62}$

El Artículo 3 común a los convenios de Ginebra de 1949 destaca: 1. a): "Los atentados contra la vida y la integridad corporal, especialmente los tratos crueles, la tortura y los suplicios." En este caso, el señor Ángel fue sometido a tortura psicológica y física con ocasión al conflicto armado interno colombiano por parte de los paramilitares.

Por otro lado, producto de la tortura también se desconoció el Protocolo II de 1977 Adicional a los Convenios de Ginebra de 1949 en Artículo 4.2 a) "Los atentados contra la integridad física o mental de las personas, en particular los tratos crueles tales como la tortura o toda forma de pena corporal."

\subsubsection{Crimen Internacional de Tortura}

Crimen de Lesa Humanidad: “A los efectos del presente Estatuto, se entenderá por "crimen de lesa humanidad" cualquiera de los actos siguientes cuando se cometa como parte de un ataque generalizado o sistemático contra una población civil y con conocimiento de dicho ataque (...)" (Estatuto de Roma, artículo 7).

Crimen de Guerra: "La corte tendrá competencia respecto de los crímenes de guerra en particular cuando se cometan como parte de un plan o política o como parte de la comisión en gran escala de tales crímenes."(Estatuto de Roma, artículo 8).

\subsubsection{La Tortura como Parte de un Ataque Generalizado o Sistemático}

La Corte Interamericana de Derechos Humanos brinda un ejemplo de un ataque generalizado y sistemático en el caso de Manuel Cepeda Vargas. La Corte citó una entrevista del entonces fiscal general Mario Iguarán “Tanto en el caso de Luis Carlos Galán como en el de Manuel Cepeda, se advierte un ataque sistemático, generalizado y subjetivo contra el Nuevo Liberalismo y la Unión Patriótica, respectivamente, lo cual permite predicar un exterminio, en consecuencia un delito de lesa humanidad (...) (p.16). En estos casos, los ataques fueron dirigidos contra una población determinada como fue contra los miembros del partido político colombiano de la Unión Patriótica (UP) y contra el ex candidato presidencial Luis Carlos Galán.

En el caso concreto, los paramilitares atacaron a la población civil de Buenaventura, a todo el que se atrevió a desafiar sus actividades ilícitas y aquellos lugareños que los paramilitares tuvieron la mera sospecha de ser colaboradores de las FARC o el ELN, fueron blanco de sus ataques.

${ }^{62}$ Protocolo II Adicional a los Convenios de Ginebra de 1949 relativo a la protección de las víctimas de los conflictos armados sin carácter internacional de 1977, articulo 1. 
Estos ataques sistemáticos o generalizados los definió la Corte Suprema de Justicia en la sentencia contra el general en retiro Maza Márquez, de la siguiente manera:

Con esto se demuestra el accionar sistemático del Cartel de Medellín contra todo el que se opusiera o amenazara sus ilegítimos intereses, valga decir, fue un plan criminal ejecutado a través de una pluralidad de acciones guiadas por el mismo patrón de conducta, con identidad de propósito y dirigido contra un grupo específico de individuos. (Corte Suprema de Justicia. Sentencia, Miguel Maza Márquez, 2016, p. 60-61).

La Fiscalía General de la Nación declaró como delitos de lesa humanidad y crímenes de guerra los casos de integrantes de la Unión Patriótica, basada en las declaraciones de la Corte Suprema de Justicia y la Corte Interamericana de Derechos Humanos además de la asociación de casos conseguida con el contexto realizado en 34 casos de la Unión Patriótica, ya que se logró determinar que estos fueron casos de exterminio y ejecución general, reiterada y sistemática dentro del conflicto interno. Estos ataques cometidos por grupos paramilitares, en algunos casos, en asociación con agentes del Estado, ataques generalizados, sistemáticos reiterados contra la población civil. ${ }^{63}$

La Fiscalía se pronunció también sobre el caso de Jaime Garzón para declararlo como crimen de lesa humanidad, basándose en que el homicidio del humorista ocurrió en un contexto generalizado de agresiones a defensores de Derechos Humanos (...), estos ataques a este grupo poblacional aumentaron considerablemente, tal y como lo han señalado los informes anuales de la ONU Derechos Humanos. ${ }^{64}$

Los ataques de los paramilitares en buenaventura fueron contra la población civil y tenían el siguiente modus operandi: ${ }^{65}$

\footnotetext{
${ }^{63}$ Dirección Nacional de Análisis y Contextos (DINAC) de la Fiscalía. Declara casos de integrantes de la UP como crímenes de lesa humanidad. Boletín No.8037 del 20 de octubre de 2014. Recuperado de https://www.fiscalia.gov.co/colombia/noticias/destacada/fiscaliadeclara-casos-de-integrantes-de-la-up-como-crimenes-de-lesa-humanidad/

${ }^{64}$ Dirección de la Fiscalía Nacional de Derechos Humanos y Derecho Internacional Humanitario. Homicidio del humorista Jaime Garzón es de lesa humanidad: Fiscalía. Boletín No.15975 del 30 de septiembre de 2016 . Recuperado de https://www.fiscalia.gov.co/colombia/noticias/homicidio-del-humorista-jaime-garzon-es-de-lesa-humanidad-fiscalia/

${ }^{65}$ Expresión latina, que refiere el modo criminal de obrar de una o más personas.
} 
Ilustración 1. Protocolo de actuación en las masacres

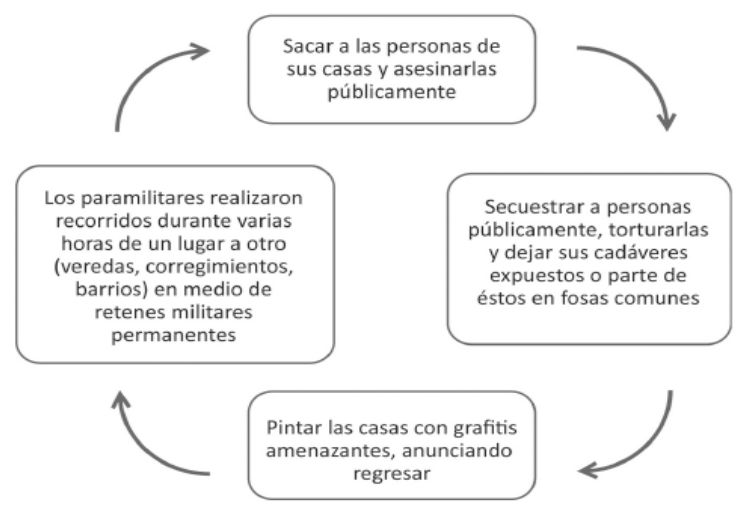

Gráfico 7. Centro Nacional de Memoria Histórica. (2015). Ilustración 1.Protocolo de Actuación en las Masacres. [Ilustración]. Recuperado de: http://www.centrodememoriahistorica.gov.co/micrositios/buenaventura/

La tortura física y psicológica que sufrió el señor Luis Ángel fue por obra de los paramilitares en Buenaventura, en el marco de un ataque sistemático como represaría a las labores de líder social que ejerció en la ciudad puerto. Estás labores sociales fueron catalogadas por los paramilitares como una amenaza para cumplir con sus ilegítimos intereses tales como las extorsiones, el reclutamiento de menores de edad, el micro y narcotráfico.

\subsubsection{La Tortura Bajo un Plan o Política}

El caso de Manuel Cepeda Vargas vs Colombia (2010), es un caso donde se pueden extraer nociones importantes sobre política y plan criminal. La Corte Interamericana de Derechos Humanos en este caso afirmó: "Independientemente de la existencia de un plan específicamente denominado "golpe de gracia", la Corte considera que sí existió una estructura organizada que determinó, planificó y llevó a cabo la ejecución del Senador Cepeda Vargas" (p.38).

La tortura padecida por Don Ángel Sinisterra se presentó en el año 2005. Esta época en Buenaventura fue conocida por los lugareños y registrada en informes ${ }^{66}$ como la época de las mil muertes. En este periodo alias "H.H" comandó al Bloque Calima e ideó el plan de asesinar a mil personas en la ciudad puerto. Dicho plan consistió asesinar a mil personas para controlar Buenaventura a través del terror. Los asesinatos se basaron bajo el supuesto de la lucha antisubversiva según Centro Nacional de Memoria Histórica (2015), informe Buenaventura un Puerto sin Comunidad y otros bajo el supuesto de limpieza social “( ...) $\mathrm{HH}$ ordenó mil muertes para Buenaventura (...) entonces busquemos un marihuanerito, hacían como un listado y mataban a estos tipos (...)" (CNMH, entrevista, mujer líder comunitaria, noviembre de 2013).

${ }^{66}$ Centro Nacional de Memoria Histórica-CNMH, Buenaventura: Un Puerto sin Comunidad y también en los informes de Rutas del Conflicto sobre las masacres en Buenaventura. 
Existió un plan de los paramilitares en Buenaventura en el cual las matanzas fueron con aquiescencia de los agentes estatales, al permitir que se llevaran a cabo las masacres como según lo afirmó Cinep ${ }^{67}$ (s.f.) citado por Rutas del Conflicto (s.f.) ${ }^{68 ،(. . .)}$ antes de estos hechos los 'paras' pasaron cerca de un retén permanente de los batallones Pichincha y Palacé, en la vereda El Danubio y una vez terminaron la masacre se dirigieron a bases militares." Aquiescencia que también lo afirmó el Centro Nacional de Memoria histórica en su informe de Buenaventura: Un puerto sin comunidad, de la siguiente manera:

Cabe señalar, que la "libertad" con la que se ejecutó la destrucción y la violencia que caracterizaron a las masacres se llevó a cabo debido a la facilidad que tuvieron los grupos paramilitares de movilizar a un gran número de hombres armados en diferentes vehículos, pese a que en esta región existía una serie de retenes militares cerca de los sitios donde ocurrieron los hechos de violencia.

(Centro Nacional de Memoria Histórica, 2015, p.275)

Así mismo, para el portal web y periodístico Verdadabierta.com (2015), el éxito de las políticas paramilitares en Buenaventura se debió en parte a la aquiescencia entre paramilitares y agentes estatales, "una razón que explica por qué los paramilitares se hicieron rápidamente con el control de la ciudad-puerto, además del apoyo de sectores de la fuerza pública y de narcotraficantes".

Para la Corte Suprema de Justicia, en el caso del ex congresista Cesar Pérez García ${ }^{69}$, definió la noción de planificación; cuando hay confluencia de los actores de todo orden, quienes concurren en la ejecución de las masacres, se concertan previamente y de esa manera incurren en la participación de los delitos. La Corte en este mismo caso, declaró los hechos como crimen de lesa humanidad por la gravedad y la generalidad de los hechos que realizaron los paramilitares contra la población civil.

En la sentencia contra el general en retiro Miguel Alfredo Maza Márquez por el asesinato de asesinato de Luis Carlos Galán la Corte expresó lo siguiente frente a un plan criminal:

(...), así como lo concluyó la Fiscalía, la Corte también arriba al convencimiento de que el homicidio de Luis Carlos Galán Sarmiento hizo parte de un plan criminal preconcebido por Pablo Emilio Escobar Gaviria, caracterizado por la pluralidad de acciones violentas, marcadas por el absoluto desprecio por la vida y la dignidad humana, provenientes de una organización criminal armada, con estructura piramidal y un

\footnotetext{
${ }^{67}$ Centro de Investigación y Educación Popular, fundada en 1972 por la Compañía de Jesús.

${ }^{68}$ Rutas del Conflicto. (s.f.). Masacre de Zabaletas 2000. Recuperado de http://rutasdelconflicto.com/interna.php? masacre=175

${ }^{69}$ Corte Suprema de Justicia, Sala de Casación Penal. Caso Cesar Pérez García, 15 de mayo de 2013.
} 
jefe máximo a la cabeza (...) (Corte Suprema de Justicia. Sentencia, Miguel Maza Márquez, 2016, p. 60-61).

Analizando las anteriores fuentes, se puede concluir que la tortura que padeció Don Ángel fue fruto de un plan y una política ejecutada por los paramilitares del Bloque Calima en Buenaventura, debido a que la tortura se presentó en un contexto histórico de violencia, que facilitó las acciones criminales de los grupos paramilitares. Dichos grupos tenían un plan denominado como "las mil muertes"; este plan tuvo éxito al contar con una política de aquiescencia con agentes estatales y además había un conocimiento y una intensión en los actores de esta tortura.

En consecuencia, la tortura que vivió Don Ángel es un crimen internacional ya que reúne los elementos que constituyen un crimen de guerra como, haber sucedido la tortura bajo un plan o política de los paramilitares del Bloque Calima en cumplimiento del plan conocido como "las mil muertes" y auspiciado en complicidad de las fuerzas estatales.

Así como también la tortura padecida por el señor Ángel reúne los elementos del crimen de lesa humanidad ya que fue en el marco de un ataque sistemático llevado a cabo por los paramilitares y se caracterizó por una fuerte represión contra la población civil de Buenaventura. El ataque fue dirigido especialmente aquellos que se opusieron al accionar paramilitar del Bloque Calima.

\subsubsection{Derecho Penal Internacional}

El Estatuto de Roma en el artículo 7, Crímenes de Lesa Humanidad, numeral 1. F) Tortura. Artículo 7 Crímenes de lesa humanidad, numeral 2. E) "Por "tortura" se entenderá causar intencionalmente dolor o sufrimientos graves, ya sean físicos o mentales, a una persona que el acusado tenga bajo su custodia o control..."

El señor Ángel Sinisterra fue sometido a sufrimientos físicos y mentales, fue abofeteado humillado, además le manifestaron que continuarían golpeándolo hasta matarlo, desaparecerlo y atentar contra su familia, lo cual indica que fue sometido a una tortura psicológica por parte del grupo paramilitar que operó en Buenaventura al mando de alias "Tabano", fue quien ordenó la tortura en contra de Don Ángel por no estar de acuerdo con sus planes. Dichos planes eran parte de un ataque sistemático dirigido contra la población civil principalmente defensores de derechos humanos, líderes sociales y opositores allí en la ciudad puerto.

\section{El Desplazamiento Forzado}

A continuación bajo un esquema normativo integral, se analizan normas nacionales e internacionales, jurisprudencia nacional e internacional y softl aw a fin de ampliar la noción de desplazamiento forzado la cual se aplicará al caso concreto. 


\subsection{Normas y Estándares Internacionales de Derechos Humanos sobre Desplazamiento Forzado}

Las guerras han generado el desplazamiento forzado de personas, las cuales huyen de los estragos que generan las mismas. Desde la segunda guerra mundial, surge la necesidad de internacional de proteger a estas personas. Es por eso que la ONU adoptó la Convención sobre el Estatuto de los Refugiados de $1951^{70}$.

Esta Convención busca la protección y asistencia de las personas desplazadas forzadamente. También las personas desplazadas forzadamente son protegidas en los principios rectores de los desplazamientos internos ${ }^{71}$. La diferencia entre la Convención y los Principios es que, los Principios Rectores incluyen la noción del desplazamiento forzoso interno (DFI).

Los principios rectores definen la noción de desplazado interno de la siguiente manera:

A los efectos de estos principios, se entiende por desplazados internos a las personas o grupos de personas que se han visto forzadas u obligadas a escapar o huir de su hogar o de su lugar de residencia habitual, en particular como resultado o para evitar los efectos de un conflicto armado, de situaciones de violencia generalizada, de violaciones de los derechos humanos o de catástrofes naturales o provocadas por el ser humano, y que no han cruzado una frontera estatal internacionalmente reconocida. (Principios rectores de los desplazamientos internos, 1998, Introducción. 2)

La anterior noción del desplazamiento forzado interno es recogida a su vez por la Consulta Permanente para los Desplazados Internos en las Américas según Atebortúa Arredondo (2009). ${ }^{72}$

El desplazamiento forzado se refiera a una situación que toman las personas al escapar de los conflictos armados, la violencia, las persecuciones y como tal de las violaciones de derechos humanos. Actualmente 60 millones de personas han sido desplazadas a la fuerza en el mundo, de las cuales 38.2 millones corresponden a desplazados internos. ${ }^{73}$

\footnotetext{
${ }^{70}$ Convención sobre el Estatuto de los Refugiados. Adoptada en Ginebra, Suiza, el 28 de julio de 1951 por la Conferencia de Plenipotenciarios sobre el Estatuto de los Refugiados y de los Apátridas (Naciones Unidas), convocada por la Asamblea General en su resolución 429 (V), del 14 de diciembre de 1950.

${ }^{71}$ ONU, Principios rectores de los desplazamientos internos. Resolución de la Comisión de Derechos Humanos 11 de febrero de 1998.

${ }^{72}$ Atebortúa Arredondo C. (2009). Diálogos de Saberes. Límites para el Concepto del Desplazamiento Forzado Intraurbano. El Papel de la Acción de Tutela y de la Jurisprudencia en su Construcción. Revista (30), 241-260. doi: file:///C:/Users/felipe/Downloads/DialnetLimitesParaElConceptoDeDesplazamientoForzadoIntrau-3224480.pdf

${ }^{73}$ Banco Mundial. (2015). Preguntas frecuentes: El Desplazamiento Forzado, Una Crisis Mundial Cada Vez Mayor. Recuperado de http://www.bancomundial.org/es/topic/fragilityconflictviolence/brief/forced-displacement-a-growing-global-crisis-faqs
} 
Según el Centro Nacional de Memoria Histórica (2015), "El desplazamiento forzado consiste en el desalojo involuntario de la población civil de sus territorios". ${ }^{74}$

Para Velázquez Moreno (2017), el desplazamiento forzado interno causado por el conflicto armado, situaciones de violencia generalizada y violaciones de derechos humanos tienen un efecto preventivo o reactivo. El preventivo es cuándo se huye del conflicto armado, conflicto social o violencia ocasionado por previas amenazas, ofensas, insultos, partiendo de un suceso o conflicto violento previamente acontecido el cual la población que se desplaza tiene conocimiento. Por su parte el Reactivo es el daño ocasionado por cualquier motivo y bajo un contexto de violencia. ${ }^{75}$

\section{Análisis Concreto del Caso}

El señor Ángel Sinisterra, fue víctima de desplazamiento forzado en dos ocasiones por parte de los grupos paramilitares en la ciudad de Buenaventura Valle del Cauca.

\section{El Primer Desplazamiento Forzado}

La primera vez que se desplazó fue en el año 2007, en ese año se desplazó acompañado de algunos de sus familiares hacia la ciudad de Ibagué-Tolima, porque previamente fue torturado y recibió amenazas de atentar contra su integridad y la de su familia por parte de paramilitares del Bloque Calima.

\section{El Segundo Desplazamiento Forzado}

En el año 2011 Don Ángel retornó a Buenaventura, se quedó a vivir en este municipio hasta el año 2013, año en el cual miembros del grupo paramilitar Los Urabeños obligaron a Don Ángel junto a su familia a desplazarse de Buenaventura. Este año -2013- las AUC durante el conflicto armado interno colombiano desplazaron forzadamente a 13.000 personas sólo en Buenaventura, según Human Rights Watch, (2014). ${ }^{76}$

En el año 2013, Don Ángel fue amenazado junto a su familia, por parte de Los Urabeños, los cuales no solo se conformaron con amenazarlo de muerte sino que además le arrebataron uno predio ubicado en la vereda La Gloria [Comuna 12, zona rural de Buenaventura] y por este motivo el señor Ángel y su familia tuvieron que desplazarse forzosamente a la ciudad de Ibagué. Como se puede comprobar en este mismo año la organización no gubernamental, Human Rights Watch realizó un informe sobre cómo es la

\footnotetext{
${ }^{74}$ Centro Nacional de Memoria Histórica-CNMH. (2015). Buenaventura: Un Puerto sin Comunidad, (p.234).

75 Velázquez, A (2017). Desplazamiento Interno por Violencia en México. Causas, Consecuencias y Responsabilidades del Estado. Comisión Nacional de Derechos Humanos, Primera edición. Recuperado de https://archivos.juridicas.unam.mx/www/bjv/libros/11/5197/9.pdf

${ }^{76}$ Human Rights Watch (HRW). (2014). La Crisis en Buenaventura: Desapariciones, Desmembramientos y desplazamiento en el principal puerto de Colombia en el pacífico. Recuperado de https://www.hrw.org/es/report/2014/03/20/la-crisis-enbuenaventura/desapariciones-desmembramientos-y-desplazamiento-en-el
} 
situación en los barrios de Buenaventura. El informe arrojó que en los barrios bonaverenses ejercen control los grupos sucesores del paramilitarismo conocidos como La Empresa y Los Urabeños. Estos grupos son quienes hostigan a la población civil con reclutamiento de menores de edad, extorsiones y restringen la circulación de sus habitantes ${ }^{77}$.

Entre el año 2005 y el 2013 el desplazamiento forzado fue de 25.343 personas en Buenaventura, un municipio caracterizado por ser más expulsador que receptor de personas desplazadas forzosamente, según el Centro Nacional de Memoria Histórica (2015). ${ }^{78}$ En el año 2013 como se mencionó anteriormente, fue el año del segundo desplazamiento del señor Ángel, en el cual se incrementó considerablemente el desplazamiento forzado como se puede apreciar en la siguiente gráfica:

\section{Gráfica 3. Desplazamiento forzado en el municipio de Buenaventura 1995 a 2013}

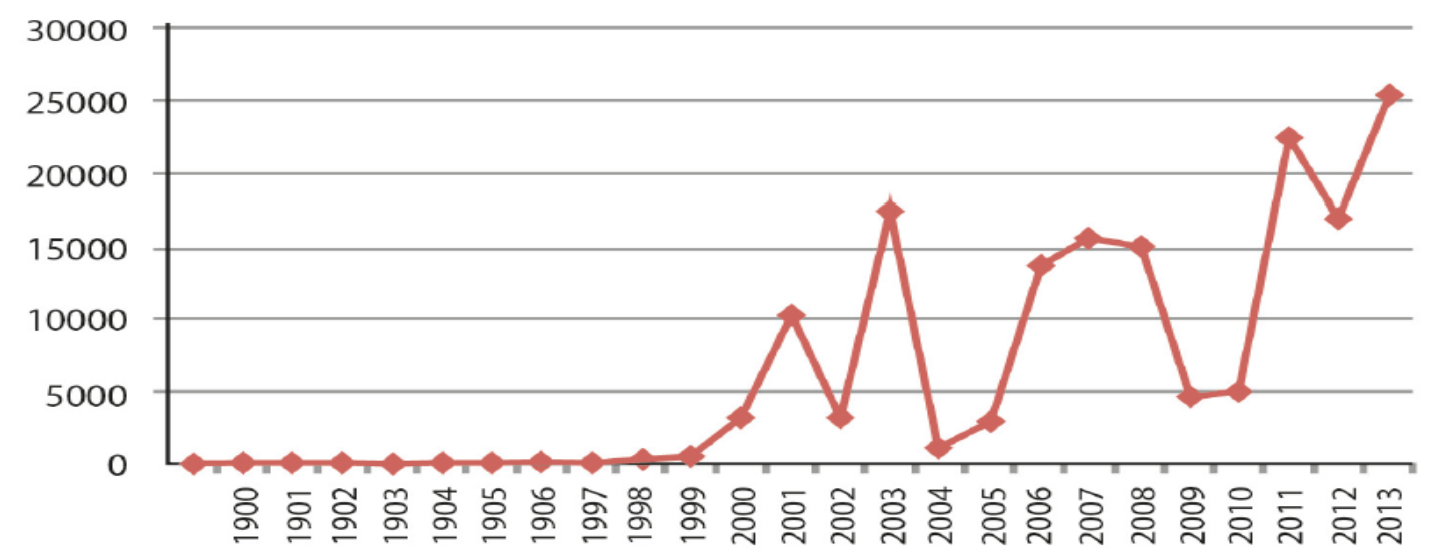

Gráfico 8. RNI, Unidad de Víctimas, (29 de agosto de 2014) citado por Centro Nacional de Memoria Histórica (CNMH). (2015). Gráfica 3. Desplazamiento Forzado en el Municipio de Buenaventura 1995 a 2013. [Gráfica]. Recuperado de http://www.centrodememoriahistorica.gov.co/micrositios/buenaventura/

Los grupos armados al margen de la ley son quienes desplazan forzadamente a la población civil a huir de sus hogares, trabajos y sus territorios mediante el uso de violencia reflejada en confrontaciones armadas, asesinatos, destrucción de bienes, amenazas y hostigamientos.

La Corte Interamericana de Derechos Humanos en el caso de las Comunidades Afrodescendientes Desplazadas de la Cuenca del Río Cacarica vs Colombia afirmó que las confrontaciones entre los grupos armados ilícitos junto con las amenazas, persecuciones, asesinatos y bloqueos económicos por control del río Atrato produjeron desplazamiento masivos de los lugareños. ${ }^{79}$

\footnotetext{
${ }^{77}$ IDEM.

${ }^{78}$ Centro Nacional de Memoria Histórica-CNMH. (2015), Buenaventura: Un Puerto sin Comunidad. (p. 235).

79 Corte Interamericana de Derechos Humanos. Caso de las Comunidades Afrodescendientes Desplazadas de la Cuenca del Rio Cacarica vs Colombia. Excepciones Preliminares, Fondo, Reparaciones y Costas. Sentencia del 20 de noviembre de 2013, párr.92.
} 
En este mismo caso para la época de los hechos varios pobladores de la cuenca del Cacarica y del bajo Atrato en general tuvieron que desplazarse, alrededor de 3.500 personas. Las causas de este desplazamiento según la Corte, fueron hechos de violencia en el contexto de la Operación Génesis y la Operación Cacarica, operaciones que fueron acompañadas de bombardeos y la muerte de Marino López Mena ${ }^{80}$.

En este sentido, fue bajo un contexto violento similar al descrito por la Corte pero en el municipio de Buenaventura, que Don Ángel padeció el desplazamiento forzado. Este además comparte con el caso expuesto por la Corte que los responsables del desplazamiento fueron los paramilitares y en aquiescencia con agentes estatales. Además, fue precedido de hostigamientos a la población civil; cabe recordar que Don Ángel fue torturado previamente y luego fue amenazado de muerte por los paramilitares, motivos por los cuales decidió abandonar su natal Buenaventura.

La Defensoría del Pueblo en su informe el Desplazamiento Forzado por La Violencia en Colombia ${ }^{81}$ (s.f.), reportó que las comunidades negras e indígenas continúan siendo gravemente afectadas por el desplazamiento forzado. Informe en el cual el desplazamiento se generó por los intereses ilícitos de los actores armados al margen de la ley, debido a que estos grupos buscan controlar las rutas para el narcotráfico en la región pacífica. Se cree que del total de la población desplazada en Colombia el 10,78 \% es afrodescendiente.

Don Ángel fue desplazado forzadamente por parte de los paramilitares quienes consideraron que su liderazgo e influencia en las comunidades afrodescendientes sería un obstáculo para alcanzar sus intereses ilícitos en la ciudad portuaria. A raíz de ello, recibió múltiples amenazas contra su vida por parte de los grupos paramilitares que lo obligaron a desplazarse de Buenaventura, afectando abruptamente su arraigo cultural y su cosmovisión ligada al territorio de su comunidad. ${ }^{82}$

\subsubsection{Marco Jurídico Nacional}

La Ley 387 de 1997 y la Corte Constitucional en las sentencias T-227 de 1997 y T-327 de 2001 recogen la anteriormente mencionada definición de desplazados internos adoptada por la ONU en la Convención sobre el Estatuto de los Refugiados de 1951.

Ley 387 de 1997 la cual tiene como finalidad la prevención del desplazamiento forzado; la atención, protección, consolidación y esta estabilización socioeconómica de los desplazados internos por la violencia en la República de Colombia. En los siguientes artículos:

\footnotetext{
${ }^{80}$ VERDADABIERTA.COM. (2011). Rito Alejo Del Río y el Asesinato de Marino López. Recuperado de https://verdadabierta.com/ritoalejo-del-rio-y-el-asesinato-de-marino-lopez/

81 Defensoría del Pueblo. (s.f.). el Desplazamiento Forzado por La Violencia en Colombia. Recuperado de http://www.defensoria.gov.co/es/public/Informesdefensoriales/765/El-Desplazamiento-Forzado-por-la-Violencia-en-Colombiadesplazamiento-forzado-en-Colombia-Informes-defensoriales---Conflicto-Armado-Informes-defensoriales---Derecho-InternacionalHumanitario

${ }^{82}$ Defensoría Del Pueblo. Resolución Defensorial Regional. (017). Sobre la situación de derechos humanos de la población desplazada en el municipio de Buenaventura. [P.15]. doi: http://www.defensoria.gov.co/attachment/256/regional17.pdf
} 
Artículo 1. "Del desplazado. Es desplazado toda persona que se ha visto forzada a migrar dentro del territorio nacional abandonando su localidad (...)"

Los desplazados forzados tienen derecho a recibir ayudas incluso de organismos internacionales, a no ser discriminados, a que se respeten sus derechos fundamentales junto con sus familias y a obtener una solución definitiva a su problema. (Artículos 2.2 al 2.9 de la ley 387 de 1997).

"Artículo 3. De la responsabilidad del Estado. Es responsabilidad del Estado colombiano formular las políticas y adoptar las medidas para la prevención del desplazamiento forzado; la atención, protección y consolidación y estabilización socioeconómica de los desplazados internos por la violencia".

\subsubsection{Derecho Penal}

El Código Penal Colombiano Ley 599 de 2000, señala en el artículo 159: "Desplazamiento Forzado de Población Civil. Deportación, expulsión, traslado o desplazamiento forzado de población civil. El que, con ocasión y en desarrollo de conflicto armado y sin que medie justificación militar, deporte, expulse, traslade o desplace forzadamente de su sitio de asentamiento a la población civil, incurrirá en (...)”.

El señor Ángel fue desplazado forzadamente por parte de los paramilitares y con ocasión al conflicto armado por ser una persona que se opuso a la incursión paramilitar por medio denuncias e invitando a sus vecinos a hacer lo mismo. Además, el señor Ángel se tuvo que ubicar en la ciudad de Ibagué porque el Estado debió prever el desplazamiento forzado garantizando la seguridad en Buenaventura dentro de sus habitantes, los cuales se vieron obligados a huir por la violencia que se manifestó en la ciudad portuaria. Los auxilios por parte del Gobierno no fueron eficientes, fueron tardíos, desconociéndose así sus derechos establecidos la Ley 387 de 1997.

A lo largo de su desplazamiento en el año 2007, el señor Ángel solicitó ayudas al Estado para él y su familia las cuales no han sido eficaces y no han solucionado sus problemas derivados a su desplazamiento como son el desempleo, desintegración de su núcleo familiar y sus proyectos de vida. A Don Ángel no le quedó más remedio que llegar a un barrio humilde carente de servicios públicos de Ibagué, habitado en su mayoría por afrodescendientes víctimas del conflicto armado colombiano.

\subsubsection{Marco Jurídico Internacional}

El desplazamiento forzado es un crimen de lesa humanidad que está contemplado así en los mecanismos e instrumentos internacionales que lo prohíben e indican que los Estados deben sancionarlo. De igual forma, según el Estatuto de Roma, el artículo 7.2 D) Contempla el desplazamiento forzado como un crimen de lesa humanidad.

En el caso del señor Ángel reúne los requisitos de crimen de lesa humanidad. Es decir, fue un ataque en curso con masivas violaciones de derechos humanos, el ataque fue dirigido a 
la población civil de Buenaventura y este fue sistemático orquestado por un plan de los paramilitares para tener el control total de la ciudad de Buenaventura.

A raíz de los conflictos armados, son masivos los desplazamientos forzados, y en este sentido, los Estados están obligados a prevenir y sancionar el desplazamiento forzado pero también brindando la asistencia humanitaria.

\subsubsection{Derecho Internacional de los Derechos Humanos}

Los Estados se comprometen a cumplir con lo pactado en los tratados internacionales los cuales buscan proteger el derecho de circulación y el de residencia ${ }^{83}$. Pese a lo anterior, se vulneraron los derechos de los ciudadanos, generando un abandono estatal que puede revictimizar a los desplazados forzados, como le ocurrió a Don Ángel Sinisterra, quien se vio obligado a huir de Buenaventura por la violencia y el temor de que atentaran contra su integridad.

\subsubsection{Sistemas de Protección de Derechos Humanos}

\section{Sistema Universal de Derechos Humanos}

En el ámbito internacional más específicamente en el sistema universal se encuentran "Los Principios Rectores de Los Desplazamientos Internos del Representante Especial del Secretario General de la ONU. ${ }^{84}$

El Principio 1. El Estado tiene la obligación de proporcionar necesidades vitales como alimentos, medicinas y viviendas. ${ }^{85}$

El principio 3 del informe en mención los Estados deben elaborar marcos normativos e instituciones adecuadas para protección y asistencia de las personas desplazadas y que permitan la ayuda humanitaria internacional. Estos Principios "se aplicarán sin distinción alguna de raza, color, sexo, idioma, religión o creencia, opinión política o de cualquier otra índole (...)" y 9. "Los Estados tienen la obligación específica de tomar medidas de protección contra los desplazamientos de pueblos minorías (...)”.

El principio 11.2 "los desplazamientos internos serán protegidos especialmente contra tortura (...)" y el Principio 18 "Los desplazados tienen derecho a vivienda digna, agua potable vestuario".

\footnotetext{
${ }^{83}$ Convención Americana sobre Derechos Humanos, 1969, art.22 y 27.

${ }^{84}$ Asamblea General de las Naciones Unidas. Principios Rectores de los Desplazamientos Internos. Informe E/CN.4/1998/53/Add.2 del Representante del Secretario General, Sr. Francis M. Deng. 11 de febrero de 1998.
} 
Sobre la inasistencia de las instituciones del estado frente a la problemática del desplazamiento forzado en Buenaventura la ONG internacional Human Rights Watch afirmó lo siguiente:

Las autoridades de Buenaventura no han brindado asistencia adecuada a víctimas de desplazamiento forzado luego de que debieron abandonar sus hogares. Las medidas oficiales destinadas a ayudar a personas desplazadas — exigidas en las leyes colombianas - se han distinguido por problemas como acogida provisional en sitios de albergue inadecuados, demoras en la prestación de asistencia humanitaria y la falta de protección de las propiedades que abandonan las víctimas para evitar su destrucción u ocupación por grupos sucesores. (Human Rights Watch, 2014, p.1). ${ }^{86}$

La Defensoría del Pueblo sobre la asistencia de las víctimas aduce que el desplazamiento forzado alcanzó la cifra de 80.000 personas en el valle del cauca al año 2003. Ante dicha situación, el Estado presenta una precariedad en sus instituciones para actuar y para desarrollar políticas públicas. La presencia del Estado es muy débil en la zona de conflicto lo cual ha facilitado el control y los esquemas de poder por parte de los grupos armados ilegales ${ }^{87}$.

El Estado colombiano no lo garantizó frente al caso del señor Ángel, quien empezó a denunciar los hechos criminales de los paramilitares en su barrio ante el personero municipal él cual según Don Ángel le aconsejó abandonar Buenaventura porque no tenía los medios para protegerlo. Don Ángel también acudió a la fiscalía de Buenaventura y esta no pudo brindarle protección. Al no brindarle protección Don Ángel huyó a Ibagué.

También, pese a que Don Ángel es afrocolombiano y al grupo al que pertenece en su natal Buenaventura tiene un apego particular a la tierra no fue asistido y protegido debidamente por el Estado, vulnerándose de esta manera los principios de la ONU para las personas desplazadas internamente.

Al ser estos territorios constantemente transitados por los grupos armados ilegales en el contexto del conflicto armado interno ponen en riesgo a los miembros de las comunidades afrodescendientes e impiden que puedan trabajar la tierra ya es ocupada por los cultivos ilícitos de los grupos armados al margen de la ley, los cuales obligan a desplazar forzadamente a las comunidades. El Desplazamiento Forzado genera una agresión a su

\footnotetext{
${ }^{86}$ Human Rights Watch. (20 de maro de 2014). La Crisis en Buenaventura: Desapariciones, Desmembramientos y Desplazamiento en el Principal Puerto de Colombia en el pacífico. Recuperado de https://www.hrw.org/es/report/2014/03/20/la-crisis-enbuenaventura/desapariciones-desmembramientos-y-desplazamiento-en-el

${ }^{87}$ Defensoría Del Pueblo. (septiembre de 2003).Resolución Defensorial Regional. (017). Sobre la situación de derechos humanos de la población desplazada en el municipio de Buenaventura. [p.3-4]. doi: http://www.defensoria.gov.co/attachment/256/regional17.pdf
} 
cosmovisión y a su cultura muy arraigada al territorio según la Defensoría del Pueblo (2003). ${ }^{88}$

Como se menciona anteriormente en el contexto el señor Ángel llegó a un barrio de Ibagué que no cuenta con condiciones mínimas de vida.

\section{Sistema Interamericano de Derechos Humanos}

Ángel Siniestra al ser un ciudadano colombiano tiene el derecho de transitar y residir en el territorio nacional como lo indica La Convención Americana De Derechos Humanos, en su artículo 22.1. De igual modo, afirma la presente Convención que a nadie se le puede privar su derecho a circular o de residencia tampoco ha ser expulsado o privado de ingresar al territorio (artículos 22.3 y 22.5). En Buenaventura Ángel Siniestra fue expulsado por los paramilitares y se le prohibió volver por medio de amenazas de muerte.

\subsubsection{Derecho Internacional Humanitario}

Para el Derecho Internacional Humanitario la noción de quienes son personas desplazadas se encuentra en los Principios rectores de los desplazamientos internos de 1998 y afirma que es una noción es el resultado de una combinación que reúne las ramas del derecho internacional público, derecho de los derechos humanos, derecho de los refugiados y el derecho internacional humanitario.

Para el Derecho Internacional Humanitario, las personas desplazadas en el interior de su país por ser víctimas de un conflicto armado, están protegidas por el derecho internacional humanitario. Este vínculo existe dado que los conflictos armados producen desplazamientos forzados en la población civil que huye de los nefastos efectos de la guerra.

El derecho internacional humanitario además de proteger a las personas desplazadas tiene también un sentido de prevención, el cual consiste en prevenir los desplazamientos forzados cuando se exige el respeto de las normas del derecho internacional humanitario. De aquí, se afianza la existencia de los protocolos adicionales a los convenios de Ginebra de 1977 en los que se reafirma la protección a las víctimas de desplazamientos forzados en los conflictos armados. Mediante estos dos protocolos adicionales se obliga a los Estados a respetar las normas de Derecho Internacional Humanitario frente a las personas en condición de desplazamiento por conflictos armados ya sea de carácter internacional o interno. ${ }^{89}$

\footnotetext{
${ }^{88}$ Defensoría Del Pueblo. (septiembre de 2003).Resolución Defensorial Regional. (017). Sobre la situación de derechos humanos de la población desplazada en el municipio de Buenaventura. [p.15]. doi: http://www.defensoria.gov.co/attachment/256/regional17.pdf

${ }^{89}$ Comité Internacional de la Cruz Roja. (1998). Principios Rectores relativos al desplazamiento de personas en el interior de su propio país. Recuperado de https://www.icrc.org/es/doc/resources/documents/misc/5tdmg6.htm
} 


\section{Caso Concreto}

En el caso sub judice Don Ángel fue víctima del desplazamiento forzado en el municipio de Buenaventura con ocasión al conflicto armado interno. Fue desplazado en dos oportunidades debido a las amenazas recibidas de atentar contra su integridad y contra la de su familia, por parte de los grupos armados al margen de la ley que hacían presencia en Buenaventura bajo un contexto del conflicto armado colombiano.

Don Ángel fue obligado a desplazarse por orden de las AUC que operaban en Buenaventura, Violando así Protocolo Adicional II de 1977 a los convenios de Ginebra de 1949, en su artículo 17. Prohibición de los Desplazamientos Forzados, numeral 2. No se podrá forzar a las personas civiles a abandonar su propio territorio por razones relacionadas con el conflicto.

\subsubsection{Crimen Internacional del Desplazamiento Forzado}

Crimen de Lesa Humanidad: "A los efectos del presente Estatuto, se entenderá por "crimen de lesa humanidad" cualquiera de los actos siguientes cuando se cometa como parte de un ataque generalizado o sistemático contra una población civil y con conocimiento de dicho ataque (...)" (Estatuto de Roma, artículo 7).

Crimen de Guerra: "La corte tendrá competencia respecto de los crímenes de guerra en particular cuando se cometan como parte de un plan o política o como parte de la comisión en gran escala de tales crímenes."(Estatuto de Roma, artículo 8).

\subsubsection{EI Desplazamiento Forzado como parte de un Ataque}

La Defensoría del Pueblo (s.f.) plantea frente al desplazamiento por violencia que "el desplazamiento forzado de población continúa siendo la más evidente manifestación del irrespeto sistemático de los actores armados al Derecho Internacional Humanitario" (p.2). ${ }^{90}$ Es el desplazamiento forzado un ataque sistemático contra la población civil, los diferentes actores armados tienen en común que su blanco es la población civil cuya dinámica es mediante el conflicto y la violencia desplazar a los civiles para apoderarse de sus tierras y convertirlas en zonas de cultivos ilícitos. Estos ataques además de ser dirigidos a la población civil también van dirigidos a sus bienes como sus territorios.

En el caso de Don Ángel Sinisterra él fue desplazado forzadamente por los paramilitares los cuales además de desplazarlo, se apoderaron de un predio de su posesión ubicado en la

\footnotetext{
${ }^{90}$ Defensoría del Pueblo. (s.f). El Desplazamiento Forzado por la Violencia en Colombia. Informe Defensorial sobre el Desplazamiento $\begin{array}{lllllll}\text { Forzado por la } & \text { la } & \text { Volombia } & \text { doi: }\end{array}$ http://www.defensoria.gov.co/attachment/48/El\%20Desplazamiento\%20Forzado\%20por\%20la\%20Violencia\%20en\%20Colombia\%20 .pdf
} 
vereda La Gloria, de Buenaventura. Afirmó Don Ángel que cuando fue a ver su predio unos sujetos se identificaron como miembros del grupo paramilitar de Los Urabeños quienes le informaron que ese predio ya no era de él y además era aprovechado para cultivos ilícitos.

De acuerdo con la propia Corte Penal Internacional, el desplazamiento forzoso como crimen de lesa humanidad tiene como elemento que "el autor haya deportado o trasladado por la fuerza, sin motivos autorizados por el derecho internacional y mediante la expulsión u otros actos de coacción, a una o más personas a otro Estado o lugar”, y aclara que se entiende que la expresión "por la fuerza" no se limita a la fuerza física, sino que se puede incluir la amenaza de la fuerza o la coacción, como la causada por el temor a la violencia, la intimidación, la detención, la opresión psicológica o el abuso del poder, contra esa o esas personas u otra o aprovechando un entorno de coacción.(Comisión Nacional de los Derechos Humanos, 2017, p. 57)

Don Ángel fue desplazado forzadamente por parte de los paramilitares en Buenaventura, previamente fue detenido y torturado. Además los paramilitares no solo usaron la fuerza sino también el temor a la violencia, puesto que el señor Ángel fue amenazado de ser asesinado junto a su familia, lo cual constituye una opresión psicológica por las constantes maneras en las que él y su familia fueron amenazados como por ejemplo personalmente en la puerta de su casa, en el centro de la ciudad y mediante llamadas telefónicas.

\subsubsection{El Desplazamiento Forzado bajo un Plan o Política}

La Corte Interamericana de Derechos Humanos en el caso Plan de Sánchez vs Guatemala ${ }^{92}$, identificó un plan o política que usó el ejército guatemalteco contra los miembros del pueblo indígena Maya. En este marco, bajo la "Doctrina de Seguridad Nacional" consideró a los Mayas como enemigos internos y los acusó de ser guerrilleros por lo cual el ejército realizó masacres y empleó técnicas militares como tierra arrasada con la cual destruyó sus bienes, plantaciones, ganado sus símbolos culturales, instituciones sociales, económicas, políticas y religiosas.

Para el caso de Don Ángel resulta similar que con el pretexto de combatir insurgencia guerrillera, los paramilitares señalaban a cualquier persona de ser colaborador de las FARC. Bajo esta premisa, se realizaron desplazamientos forzados en Buenaventura como por ejemplo el caso del señor Ángel en el que los Urabeños lo desplazaron por medio de amenazas y además se apropiaron de un predio ubicado en zona rural de Buenaventura. Predio que fue destinado para cultivos ilícitos.

\footnotetext{
${ }^{91}$ Comisión Nacional de Derechos Humanos, (2017). Desplazamiento Interno por Violencia en México. Causas, consecuencias y responsabilidades del Estado. Edición (1). [1-110]. doi: https://archivos.juridicas.unam.mx/www/bjv/libros/11/5197/9.pdf

${ }^{92}$ Corte Interamericana de Derechos Humanos. Caso Plan de Sánchez vs Guatemala. Fondo. Sentencia del 29 de abril de 2004, párr.42.7.
} 
La Corte interamericana en el Caso Comunidades Afrodescendientes Desplazadas de la Cuenca del Río Cacarica vs Colombia ${ }^{93}$, citando a su vez un informe de la defensoría del Pueblo ${ }^{94}$ la Corte afirmó que los paramilitares tenían la intención de tomar Riosucio ${ }^{95}$.

Los paramilitares realizaron asesinatos de campesinos y un bloqueo económico y alimentario que afectó a la población generando desplazamientos forzados en la zona. Estas acciones fueron bajo el plan paramilitar de controlar el municipio. En este mismo caso, la Corte afirmó basándose en informes de la personería de Riosucio y la Defensoría del Pueblo la existencia de una aquiescencia entre el Ejército Nacional y los paramilitares para contrarrestar el dominio y permanencia de la guerrilla de las FARC en las zonas del Atrato y la cuenca del río Cacarica. Dicha complicidad consistió en un plan premeditado en que el ejército también realizó bloqueos económicos durante meses y operaciones militares conjuntas con los paramilitares destinadas a ejercer diferentes formas de violencia sobre la población civil.

Lo anterior, generó desplazamientos forzados masivos de las comunidades de la zona. Bajo esta hipótesis el Juzgado Octavo Penal del Circuito Especializado de Bogotá afirmó que los desplazamientos y el asesinato de Marino López Mena, no fueron hechos aislados y constituyen un plan paramilitar consistente en someter mediante el terror a la población civil y tomar sus territorios. Por último, existió una versión de que el frente 57 de las FARC también hizo bloqueos de alimentos y drogas a las embarcaciones luego de tomar Riosucio.

En Buenaventura sus lugareños son afectados considerablemente por el desplazamiento forzado en el marco del conflicto armado interno. El desplazamiento forzado puede clasificarse en individual o "gota a gota" y en colectivo o masivo. El desplazamiento individual se presentó con mayor frecuencia en Buenaventura que el desplazamiento masivo en el periodo de posnegociación, debido a un plan o política de los actores armados para ocultar la violencia en Buenaventura.

El desplazamiento masivo es vistoso y bulloso llamando la atención de las autoridades, comunidades y medios de comunicación, por su parte el desplazamiento individual o "gota a gota" es más silencioso y más difícil de percibir o identificar. Según el Centro Nacional de Memoria Histórica (2015). ${ }^{96}$

\footnotetext{
${ }_{93}$ Corte Interamericana de Derechos Humanos. Caso Comunidades Afrodescendientes Desplazadas de la Cuenca del Rio Cacarica (Operación Génesis) vs Colombia. Excepciones Preliminares, Fondo, Reparaciones y Costas). Sentencia del 20 de Noviembre de 2013, Párr.95.

${ }^{94}$ Defensoría del Pueblo. Resolución Defensorial No. 025 Sobre las Violaciones Masivas de Derechos Humanos y Desplazamiento Forzado en la Región del Bajo Atrato Chocoano, octubre de 2002 (expediente de prueba, folio 230).

${ }_{95}^{95}$ Municipio ubicado en el departamento del Chocó, en la región del Urabá.

${ }^{96}$ Centro Nacional de Memoria Histórica-CNMH. (2015), Buenaventura: Un Puerto sin Comunidad. (p. 237).
} 
El desplazamiento forzado fue la modalidad de violencia más utilizada por los grupos al margen de la ley entre 1990 a 2014 expulsó a la fuerza a dos de cada cinco habitantes en Buenaventura. Según el Centro Nacional de Memoria Histórica (2015). ${ }^{97}$

Con respecto a lo anterior, el señor Ángel fue desplazado en el marco del conflicto armado en Buenaventura bajo el plan paramilitar conocido como "las mil muertes" en el cual fue torturado y posteriormente recibió múltiples amenazas de muerte por ser un líder social afrodescendiente reconocido en la comunidad por denunciar la presencia de paramilitares y sus acciones delincuenciales en los barrios de la ciudad. Motivos por los cuales fue amenazado de muerte por los paramilitares y tuvo que huir de Buenaventura junto con su familia.

Frente a la aquiescencia, Don Ángel afirma que la fuerza pública conoce la situación de inseguridad y pese a los llamados de la comunidad no hacen nada para contrarrestar el accionar de los grupos armados ilegales. Según el informe de la ONG internacional Human Rights Watch las autoridades no han garantizado protección a los bonaverenses.

Las autoridades no han protegido a la población frente a los grupos sucesores de paramilitares. Los residentes de algunas zonas de la ciudad donde la Empresa o los Urabeños ejercían fuerte poder indicaron que había poca presencia policial en sus barrios. Más preocupante aún, varios residentes señalaron haber visto a policías reuniéndose con grupos sucesores en sus barrios. En general, existe una profunda desconfianza hacia las autoridades y una sensación generalizada de indefensión ante los abusos que cometen constantemente esos grupos. (Human Rights Watch, 2014). ${ }^{98}$

Para el caso sub júdice, Don Ángel fue desplazado por los paramilitares en Buenaventura, donde existió aquiescencia entre paramilitares y miembros de la fuerza pública como también de parapolítica que facilitaron el accionar del Bloque Calima para realizar por ejemplo los desplazamientos forzados contra la población civil bonaverense. Según información que respalda el Centro Nacional de Memoria Histórica (2015) en su informe "Buenaventura: Un Puerto Sin Comunidad, esta complicidad entre paramilitares, agentes estatales y políticos consistieron en realizar operaciones planeadas y realizadas en conjunto contra la población civil bajo el pretexto de la lucha contrainsurgente. En esta cooperación se brindó apoyo logístico, transporte y hasta pagos mensuales de paramilitares a miembros

\footnotetext{
${ }^{97}$ Centro Nacional de Memoria Histórica-CNMH. (2015), Buenaventura: Un Puerto sin Comunidad. (p. 238).

${ }^{98}$ Human Rights Watch. (20 de marzo de 2014). La Crisis en Buenaventura; Desapariciones, desmembramientos y desplazamiento en el principal puerto de Colombia en el pacífico. Recuperado de https://www.hrw.org/es/report/2014/03/20/la-crisis-enbuenaventura/desapariciones-desmembramientos-y-desplazamiento-en-el
} 
de las fuerzas militares según informe noticioso del Diario El País ${ }^{99}$ y la versión libre rendida por el ex jefe paramilitar Hevert Veloza alias "H.H ${ }^{100 "}$.

\subsubsection{Derecho Penal Internacional}

En el Estatuto de Roma, el artículo 8 numeral 2. E) viii. Indica ordenar el desplazamiento de la población civil por razones relacionadas con el conflicto. Don Ángel le fue vulnerado este artículo del Estatuto de Roma ya que fue obligado a desplazarse del puerto de Buenaventura por las AUC, bajo amenazas de atentar contra su vida y la de su familia se ve obligado a desplazarse del puerto bonaverense. Integrantes de este grupo al margen de la ley en reiteradas ocasiones le ordenan a Don Ángel que se tiene que ir junto con su familia por no estar de acuerdo con sus actividades delictivas y por ser un líder social.

\section{Las Amenazas}

En esta sección se utilizaron normas nacionales e internacionales, así como tambien jurisprudencia con el fin de ampliar el concepto sobre las amenazas que se intenta explicar para su adecuación al caso concreto.

\subsection{Normas y estándares internacionales de derechos humanos sobre Amenazas}

Las amenazas atentan contra la integridad personal según la Corte Interamericana de Derechos humanos en el caso masacre de Santo Domingo vs Colombia como también en el caso de Comunidades Afrodescendientes de la cuenca del río Cacarica (Operación Génesis) vs Colombia ${ }^{101}$ afirmó que la mera amenaza atenta contra la integridad personal. Esta amenaza debe ser real e inminente y cuya conducta con la que se intimida debe estar prohibida en el artículo 5 de la Convención. ${ }^{102}$

Sobre las amenazas, La Corte también se pronunció en los siguientes casos; Valle Jaramillo vs Colombia, ${ }^{103}$ Niños de la calle (Villagrán Morales y Otros) vs Guatemala ${ }^{104}$ y Caso 19 comerciantes vs Colombia ${ }^{105}$ determinó que "(...) crear una situación amenazante o

\footnotetext{
${ }^{99}$ Unidad Investigativa El País. (30 de octubre de 2013). La Sangrienta Huella del Ex jefe Paramilitar alias H.H en el Valle del Cauca. Diario El País. Recuperado de https://www.elpais.com.co/elpais/judicial/noticias/sangrienta-huella-exjefe-paramilitar-alias-hh-vallecauca

${ }^{100}$ Éver Veloza García, alias HH, septiembre 4 de 2008, sesión: 9.2008.09.04, ubicación: 9.2008.09.04, versionado: Éver Veloza (HH): Comandante Bloque Bananero y Bloque Calima de las ACCU Fiscal 17 Justicia y Paz Nubia Stella Chávez Niño).

${ }_{101}$ Corte Interamericana de Derechos Humanos. Caso de Comunidades Afrodescendientes de la cuenca del río Cacarica (Operación Génesis) vs Colombia. Excepciones Preliminares, Fondo, Reparaciones y Costas. Sentencia del 20 de noviembre de 2013.Párr. 218.

${ }^{102}$ Corte Interamericana de Derechos Humanos. Caso Masacre de Santo Domingo vs Colombia. Excepciones preliminares. Fondo y Reparaciones Sentencia del 30 de noviembre de 2012, párr.191.

${ }^{103}$ Corte Interamericana de Derechos Humanos. Caso Valle Jaramillo vs Colombia. Fondo, Reparaciones y Costas. Sentencia del 27 de noviembre de 2008. Párr.108

${ }^{104}$ Corte Interamericana de Derechos Humanos. Caso Niños de la calle (Villagrán Morales y Otros) vs Guatemala. Sentencia 19 de noviembre de 1999. Párr.165.

${ }^{105}$ Corte Interamericana de Derechos Humanos. Caso 19 comerciantes vs Colombia. Sentencia 04 de julio de 2004. Párr. 149.
} 
amenazar a un individuo con quitarle la vida puede constituir, en algunas circunstancias, al menos, tratamiento inhumano".

Las amenazas generan en la víctima y sus familiares intranquilidad y zozobra e incluso pueden ser catalogadas como tortura psicológica ${ }^{106}$ "La amenaza consiste en la exteriorización del propósito de causar un mal a una persona, a su familia o a persona allegada." Carrasco (2010). ${ }^{107}$

Las amenazas según Carrasco Andrino (2010), son aquellas que atentan contra el bien jurídico inmaterial de la integridad personal, específicamente contra la tranquilidad del sujeto y la libertad personal. Cuya controversia en los doctrinantes, es si las amenazas son un delito de lesión o de peligro. Basta con que se perturbe el ánimo del sujeto pasivo o el sentimiento de tranquilidad de la víctima, sin necesidad de que se consuma el hecho. No obstante, debe existir un peligro real y concreto frente al bien jurídico que se intenta lesionar, es decir con el solo hecho de doblegar la voluntad de la víctima se está ante el delito de amenazas. ${ }^{108}$

\section{Análisis Concreto del Caso}

Las amenazas atentan contra el bien jurídico de la integridad personal. Al respecto la Corte Interamericana de Derechos Humanos afirmó lo siguiente:

La infracción al derecho de la integridad física y psicológica de las personas es una clase de violación que tiene diversas connotaciones de grado y que abarca desde la tortura hasta otro tipo de vejámenes, tratos crueles, inhumanos o degradantes cuyas secuelas físicas y psíquicas varían de intensidad según los factores endógenos y exógenos que deberán ser demostrados en cada situación concreta (...) (Corte Interamericana de Derechos Humanos. Caso Loayza Tamayo vs Perú.) $)^{109}$

La Corte Interamericana de Derechos Humanos en el caso Tibi vs Ecuador (2004) ${ }^{110}$, indicó que "(...) la presunta víctima recibió amenazas y sufrió hostigamientos durante el período

\footnotetext{
${ }^{106}$ Fiscalía General de la Nación. (2016). Cargos contra estudiante de derecho por amenazar a profesora que lo reprobó. Recuperado de https://www.fiscalia.gov.co/colombia/seccionales/cargos-contra-estudiante-de-derecho-por-amenazar-a-profesora-que-lo-reprobo/

107 Carrasco Andrino. (2010). Derecho Penal: Parte Especial. Amenazas y Coacciones, [1-7]. Recuperado de https://rua.ua.es/dspace/bitstream/10045/24640/2/COACCIONES_Y_AMENAZAS.pdf

${ }^{108}$ IDEM.

${ }^{109}$ Corte Interamericana de Derechos Humanos. Caso Loayza Tamayo vs Perú. Fondo. Sentencia del 17 de septiembre de 1997. Párr. 57.

${ }^{110}$ Corte Interamericana de Derechos Humanos. Caso Tibi vs Ecuador. Excepciones Preliminares, Fondo, Reparaciones y Costas. Sentencia del 07 de septiembre de 2004. Párr. 149.
} 
de su detención, que le produjeron pánico y temor por su vida. Todo ello constituye una forma de tortura (...)".

La Corte en el caso Yarce y Otros vs Colombia (2016) ${ }^{111}$, concluyó que las defensoras de derechos humanos junto con sus familiares recibieron amenazas de muerte por su labor de social. Las amenazas afectaron la integridad personal de las víctimas y estas se agravaron con la impunidad.

La Corte ya ha reiterado que la defensa de los derechos humanos sólo puede ejercerse libremente cuando las personas que la realizan no son víctimas de amenazas ni de cualquier tipo de agresiones físicas, psíquicas o morales u otros actos de hostigamiento (...) (Corte Interamericana de Derechos Humanos. Caso Yarce y Otros vs Colombia. Excepción Preliminar, Fondo, Reparaciones y Costas. Párr.192.

Para el Estado colombiano, es fundamental el derecho a la integridad personal y física, garantizándolo en su ordenamiento jurídico. Prohibiendo mediante su sanción atentar contra la integridad personal o con el solo hecho de difundir temor ya se está vulnerando este derecho como lo es con las amenazas. Estas pueden ser personalmente, por medio de panfletos, llamadas telefónicas u otros medios.

Según el Centro Nacional de Memoria Histórica, en su informe "Buenaventura: Un Puerto Sin Comunidad, (2015)" las amenazas en Buenaventura fueron el segundo hecho victimizante más grave con un total de 4.639 personas solo superado por el desplazamiento forzado. Ángel Sinisterra fue amenazado en Buenaventura por parte de grupos paramilitares además su familia también recibieron amenazas.

El señor Ángel fue amenazado de atentar contra su vida e integridad, por parte de grupos armados ilegales en más de una vez. La primera vez que recibió amenazas fue en el municipio de Buenaventura por parte de miembros del Bloque Calima entre el 2005 y el 2007, luego por Los Urabeños, en el año 2013. Ya en la ciudad de Ibagué las amenazas que recibe desde el año 2013 hasta la actualidad son por parte del ELN, el frente 21 de las FARC y por miembros de las Autodefensas Gaitanistas de Colombia (AGC). Dichas amenazas han sido de distintas maneras, personalmente, por llamadas telefónicas, mensajes de texto y panfletos. No solamente advierten de atentar contra su integridad sino que también contra la de su familia.

Con ocasión al caso de Don Ángel, se le vulneró su integridad física y psicológica, por recibir amenazas en su contra que afectaron su tranquilidad. Además algunas de estas amenazas se produjeron durante su tortura, en la cual los miembros de esa cuadrilla paramilitar le manifestaron las intenciones que tenían que sería asesinado y tirarían su

${ }^{111}$ Corte Interamericana de Derechos Humanos. Caso Yarce y Otros vs Colombia. Excepción Preliminar, Fondo, Reparaciones y Costas. Párr.127. 
cuerpo al mar. Por si fuera poco, también le dijeron que pretendían hacerle lo mismo a su familia puesto que ya conocían según ellos dónde vivían sus familiares.

En el caso concreto el señor Ángel es similar al de Tibi vs Ecuador descrito por la Corte, esto se debió a que Don Ángel recibió amenazas las cuales fueron constantes produjeron miedo, ansiedad e intranquilidad atentando de esta manera contra su integridad personal. Tanto así que fueron una tortura psicológica que coaccionó a Don Ángel a desplazarse de Buenaventura.

El señor Ángel cuando recibió las amenazas le afectó su integridad personal y aún más porque los presuntos responsables continúan libres lo cual le genera angustia y paranoia de ser perseguido por quienes lo amenazaron. Asimismo estas amenazas le impiden ejercer libremente su labor social en defensa de los derechos humanos, tal como lo afirmó La Corte Interamericana de derechos humanos en el Caso Yarce y Otros vs Colombia.

\subsubsection{Marco Jurídico Nacional}

\subsubsection{Derecho Constitucional}

En la Constitución Política de Colombia de 1991, artículo 11. Consagra "El derecho a la vida es inviolable". Al señor Ángel Sinisterra le fue vulnerado este artículo constitucional ya que fue amenazado por los grupos armados al margen de la ley.

\subsubsection{Derecho Penal}

El derecho a la integridad personal y física también está protegido por el legislador colombiano en el Código penal colombiano Ley 599 de 2000, artículo 347: “Amenazas. El que por cualquier medio apto para difundir el pensamiento atemorice o amenace a una persona, familia, comunidad o institución, con el propósito de causar alarma, zozobra o terror en la población o en un sector de ella, incurrirá (...)”.

Como se mencionó anteriormente, el señor Ángel fue amenazado de atentar contra su vida e integridad por parte de estos grupos armados ilegales primero en Buenaventura y luego en la ciudad de Ibagué.

\subsubsection{Marco Jurídico Internacional}

En los instrumentos internacionales de protección de derechos humanos se encuentra protegido el derecho a la integridad personal y física. También todo acto de violencia destinado a difundir temor o miedo que afecte la dignidad humana de las personas, como lo son las amenazas.

\subsubsection{Sistemas de Protección de Derechos Humanos}

\section{Sistema Universal de los Derechos Humanos}

En el Sistema Universal de Derechos Humanos se protege el derecho a la integridad personal mediante los Principios Rectores de los Desplazamientos Internos del 
Representante Especial del Secretario General de la ONU Informe E/CN.4/1998/Add.2. Don Ángel como se indicó antes fue amenazado lo cual para el principio 11.1 "Todo ser humano tiene derecho a la dignidad y a la integridad física, mental o moral". Y 11.C) son “actos de violencia destinados a sembrar terror". Así mismo prohíbe las amenazas.

\subsubsection{Sistema Interamericano de los Derechos Humanos}

La Convención Americana sobre Derechos Humanos de 1969, señala artículo 4.1: Derecho a la Vida. Toda persona tiene derecho a que se respete su vida. Nadie puede ser privado de la vida arbitrariamente.

Don Ángel es amenazado de muerte en reiteradas ocasiones en Buenaventura por parte de las AUC y los Urabeños donde las amenazas son hechas personalmente dada su actividad como líder afro defensor de derechos humanos y en la ciudad de Ibagué las amenazas fueron realizadas por el ELN, el frente 21 de las FARC y las AGC.

\subsubsection{Derecho Internacional Humanitario}

Según el Comité Internacional de la Cruz Roja y de la Media Luna Roja (2003), frente las amenazas afirma que el derecho internacional humanitario prohíbe las "medidas de terrorismo $(\ldots)$ ".

En el cuarto Convenio de Ginebra en su artículo 33, se estipula que "están prohibidos los castigos colectivos, así como toda medida de intimidación o de terrorismo", y en el protocolo adicional II en su artículo 4, se prohíben los actos de terrorismo" contra las personas que no participen directamente en las hostilidades o que hayan dejado de participar en ellas. Como tal las poblaciones civiles no pueden ser objeto de castigos colectivos que generen un estado de terror.

De igual forma, en el Protocolo Adicional I a los Convenios de Ginebra, artículo 51.2 y en el Protocolo Adicional II, artículo 13.2 establecen que quedan prohibidos los actos o amenazas de violencia cuya finalidad sea aterrorizar a la población civil. ${ }^{112}$

\section{Caso Concreto}

El señor Ángel padeció amenazas en las ciudades de Buenaventura e Ibagué por parte de grupos armados ilícitos bajo el contexto del conflicto armado interno. Estos grupos fueron los paramilitares, las FARC, Los Urabeños, el Frente 21 de las FARC, el ELN y los Gaitanistas. Las amenazas que recibió Don Ángel se presentaron en diferentes maneras personalmente hasta por llamadas telefónicas y por ejercer su labor como líder social defensor de derechos humanos y representante de las comunidades afrocolombianas.

\footnotetext{
112 Comité Internacional de la Cruz Roja y de la Media Luna Roja (Diciembre de 2003). Derecho Internacional Humanitario y Terrorismo: Respuestas a Preguntas Clave. Recuperado de https://www.icrc.org/es/faq/derecho-internacional-humanitario-y-terrorismorespuestas-preguntas-clave
} 
En este instrumento se encuentra el Protocolo II de 1977 Adicional a los Convenios de Ginebra de 1949, artículo 4.2 a) Los atentados contra la vida, (...) y la integridad física o mental de las personas (...).

Así mismo, el Protocolo II de 1977 Adicional a los Convenios de Ginebra de 1949, en el artículo $4.2 \mathrm{~h}$ ) prohibe las amenazas de realizar los actos mencionados.

Al señor Ángel se le vulneró lo establecido en estos dos artículos del Protocolo II ya que él fue amenazado en Buenaventura y hoy en día continúa siendo víctima de amenazas de muerte en la ciudad de Ibagué.

Crimen de Lesa Humanidad: "A los efectos del presente Estatuto, se entenderá por "crimen de lesa humanidad" cualquiera de los actos siguientes cuando se cometa como parte de un ataque generalizado o sistemático contra una población civil y con conocimiento de dicho ataque (...)” (Estatuto de Roma, artículo 7).

Crimen de Guerra: "La corte tendrá competencia respecto de los crímenes de guerra en particular cuando se cometan como parte de un plan o política o como parte de la comisión en gran escala de tales crímenes."(Estatuto de Roma, artículo 8).

\subsubsection{Las Amenazas como parte de un Ataque}

En el informe de la Comisión de Derechos Humanos de la ONU ${ }^{113}$ (citado también en el caso Defensor de Derechos Humanos y Otros vs Guatemala), arrojó la existencia de un ataque sistemático contra defensores de derechos humanos. Este ataque consistió en amenazas de muerte, actos de intimidación y violaciones a la integridad física y psicológica de las víctimas. Además el informe concluyó que los responsables eran las fuerzas armadas de Guatemala en aquiescencia con agentes no estatales.

La Corte Interamericana de Derechos Humanos en el caso Defensor de Derechos Humanos y Otros vs Guatemala ${ }^{114}$, concluyó que existió un ataque contra los defensores de derechos humanos bajo un contexto de posconflicto. El ataque consistió en amenazas de muerte y ataques contra la integridad personal de los defensores de derechos humanos, cuyos responsables fueron grupos clandestinos junto con las fuerzas armadas estatales y el mismo Estado con su favorecimiento a la impunidad de los hechos.

En el caso de Don Ángel, fueron las amenazas parte de un ataque sistemático contra los líderes y defensores de derechos humanos. Este ataque fue en dos municipios y sus responsables fueron diferentes grupos armados ilegales. En Buenaventura por parte de los paramilitares durante los periodos de 2005 al 2007 y 2011 al 2013. Por su parte en la ciudad de Ibagué los presuntos responsables fueron FARC, ELN y AGC desde el año 2013 hasta la actualidad.

\footnotetext{
${ }^{113}$ Relatora Especial Sra. Radhika Coomaraswamy (2002). Comisión de Derechos Humanos de las Naciones Unidas. INTEGRACIÓN DE los derechos humanos de la mujer y la perspectiva de género violencia contra la mujer. Periodo $58^{\circ}$ de sesiones. Recuperado de https://documents-dds-ny.un.org/doc/UNDOC/GEN/G02/113/20/PDF/G0211320.pdf?OpenElement

${ }^{114}$ Corte Interamericana de Derechos Humanos. Caso Defensor de Derechos Humanos y Otros vs Guatemala. Excepciones Preliminares, Fondo, Reparaciones y Costas. Sentencia del 28 de agosto de 2014. Párr.78.
} 
El señor Ángel Sinisterra se le vulneró su integridad personal al ser amenazado por grupos armados ilegales, los cuales usaron las amenazas de muerte causándole angustia y temor. Don Ángel afirmó que las amenazas de muerte le generaron una intranquilidad que lo afecta para llevar a cabo sus labores de líder social. Con respecto a que el Estado no ha capturado a ningún responsable de haber realizado estas amenazas, el señor Ángel padece de paranoia al sentir que es perseguido y observado cuando asiste a eventos sociales.

\subsubsection{Las Amenazas bajo un Plan o Política}

El régimen del terror en el cual se amenazó y hostigó a las comunidades afrodescendientes para promover procesos de desterritorialización, el cual genera pérdida del control del territorio, afectando a las víctimas en sus proyectos de vida y ocasionando desarraigo cultural. Según el Centro Nacional de Memoria Histórica en su informe "Buenaventura: Un Puerto sin Comunidad (2015)". ${ }^{115}$

Este informe también concluye que durante el año 2005 a 2013 en Buenaventura las amenazas fueron de las principales modalidades de violencia en las cuales se usaron medios como panfletos y grafitis. Estos grafitis fueron hechos por los paramilitares en los llamados recorridos de la muerte donde se hicieron estas amenazas con grafitis y se utilizaron incluso vehículos con aquiescencia de las fuerzas del Estado. ${ }^{116}$

El señor Ángel a causa de las amenazas que recibió por parte de los paramilitares en el año 2007 tuvo que abandonar su casa ubicada en el municipio de Buenaventura y en el año 2013 perdió un predio casa-lote ubicado en la vereda La Gloria [zona rural de Buenaventura]. Como consecuencia de las amenazas de muerte recibidas por parte de Los Urabeños.

\subsubsection{Derecho Penal Internacional}

Se afirma, que el caso de Don Angel es un crimen internacional porque el Estatuto de Roma, en el artículo 8 Crímenes de Guerra, numeral 2. C) i. Prohíbe "Los atentados contra la integridad corporal...". Como se mencionó anteriormente el señor Ángel Sinisterra fue amenazado de muerte en su natal Buenaventura, ocurrieron durante las masivas violaciones de derechos humanos tales como masacres, homicidios y torturas por parte de un actor no estatal organizado, los paramilitares en la ciudad de Buenaventura, estos contaban con una política de atacar a los pobladores de la zona, con el fin de mantenerlos controlados y evitando que pudieran impedir sus acciones ilícitas en el puerto.

Las amenazas de los paramilitares fueron dirigidas a la población civil de Buenaventura, principalmente a los defensores de derechos humanos, líderes sociales, sindicalistas y opositores que estaban en desacuerdo con sus acciones delincuenciales. Como es el caso del señor Ángel Sinisterra el cual fue amenazado por denunciar a los paramilitares y por no estar de acuerdo con sus acciones ilícitas. Cabe resaltar que también es amenazado

\footnotetext{
${ }^{115}$ Centro Nacional de Memoria Histórica-CNMH. (2015), Buenaventura: Un Puerto sin Comunidad. (p. 260).

${ }^{116}$ Centro Nacional de Memoria Histórica-CNMH. (2015), Buenaventura: Un Puerto sin Comunidad. (p. 275).
} 
posteriormente por los Urabeños en la ciudad de Ibagué fue amenazado mediante panfletos y llamadas telefónicas por las AGC y el frente las 21 FARC.

Las amenazas fueron sistemáticas, ya que los paramilitares tenían el plan de apoderarse de Buenaventura, para de esta manera controlar las rutas del narcotráfico, el tráfico de armas y la minería ilegal. Mediante el uso de la violencia contra los pobladores de la zona e infundiendo el terror entre sus habitantes. 


\section{CAPITULO IV}

\section{ACCESO A LA JUSTICIA}

De acuerdo al contexto y a los hechos vividos en Buenaventura e Ibagué, en el siguiente capítulo se exponen los esfuerzos del señor Ángel Sinisterra por acceder a la justicia, por reclamar sus derechos y por luchar contra la impunidad. Pese las violaciones a los derechos humanos y las infracciones al derecho internacional humanitario, el Estado no ha respondido de manera adecuada ante la situación de Don Ángel como víctima del conflicto armado.

\subsection{Normas y Estándares Internacionales}

Los hechos de tortura, desplazamiento forzado y amenazas padecidos por Don Ángel continúan sin ser resarcidos por el Estado. Ocasionando que persistan las vulneraciones de sus derechos. Los estándares internacionales están enfocados en garantizar los derechos de las víctimas y sobre todo subsanar las secuelas de los abusos y violaciones masivas de derechos humanos. Para De Greiff (2012) subsanar las secuelas se refiere a “(...) en primer lugar dar efecto a las normas de derechos humanos que han sido sistemática o manifiestamente violadas" (p.7). ${ }^{117}$

Entre los mecanismos encargados de velar por los derechos de las víctimas se encuentra el Sistema Integral de verdad, la justicia y la reparación y la no repetición. Para De Greiff (2012) este sistema de cuatro elementos debe trabajar de manera conjunta, que se complemente mutuamente y así poder cumplirle a las víctimas de una manera integral en su reconocimiento, participación y reparación. ${ }^{118}$

De acuerdo a lo anterior, sobre las vulneraciones padecidas por el señor Ángel, el siguiente gráfico se puede apreciar los estándares internacionales vulnerados conforme al hecho victimizante. Cabe mencionar que se realizó con el entendido que las normas nacionales e internacionales son de obligatorio cumplimiento y de carácter vinculante ante Colombia por el bloque de constitucionalidad.

\begin{tabular}{|l|l|}
\hline \multicolumn{1}{|c|}{ Hecho Victimizante } & Normas y Elementos Internacionales Afectados \\
\hline Tortura & $\begin{array}{l}\text { Convención Americana sobre Derechos Humanos de } \\
1969, \text { en su artículo 5.2. } \\
\text { Convención contra la tortura y otros tratos o penas } \\
\text { crueles, inhumanas o degradantes de 1984 en sus } \\
\text { artículos 2.1 y 2.2. } \\
\text { La Convención Interamericana para Prevenir y }\end{array}$ \\
\hline
\end{tabular}

\footnotetext{
${ }_{117}$ Asamblea General de la ONU. Consejo de Derechos Humanos. (2012). Informe del Relator Especial sobre la promoción de la Verdad, la Justicia, la Reparación y las Garantías de No Repetición, Pablo De Greiff. Recuperado de: https://www.ohchr.org/Documents/HRBodies/HRCouncil/RegularSession/Session21/A-HRC-21-46_sp.pdf

118 IDEM
} 


\begin{tabular}{|l|l|}
\hline Desplazamiento Forzado & Sancionar la Tortura de 1985, artículo 1. \\
& $\begin{array}{l}\text { Estatuto de Roma, artículo 7.2 D). } \\
\text { Los Principios Rectores de Los Desplazamientos } \\
\text { Internos del Representante Especial del Secretario } \\
\text { General de la ONU en sus artículos 1, 3, 4.1, y 11.2. } \\
\text { Además la Convención Americana De Derechos } \\
\text { Humanos, en sus artículos 22.1. 22.3 y 22.5. }\end{array}$ \\
& $\begin{array}{l}\text { Protocolo Adicional II de 1977 a los convenios de } \\
\text { Ginebra de 1949, en su artículo 17.2. } \\
\text { Estatuto de Roma, artículo 8 numeral 2. E) viii. }\end{array}$ \\
\hline Amenazas & $\begin{array}{l}\text { Los Principios Rectores de Los Desplazamientos } \\
\text { Internos del Representante Especial del Secretario } \\
\text { General de la ONU en sus artículos 11.1 y 11.C. } \\
\text { La Convención Americana sobre Derechos Humanos } \\
\text { de 1969, artículo 4.1: Derecho a la Vida. } \\
\text { El cuarto Convenio de Ginebra en su artículo 33. } \\
\text { Protocolos adicionales a los convenios de Ginebra. } \\
\text { En el protocolo adicional I en su artículo 51.2 y en el } \\
\text { Protocolo Adicional II, en sus artículos 4 y 13.2. }\end{array}$ \\
& \\
\hline
\end{tabular}

Gráfico 9. Gráfico 6. Millán E. (2019). Gráfico. Elaboración propia.

\subsection{Vía Judicial}

\subsubsection{Tortura}

En el año 2005 Don Ángel fue a la fiscalía de Buenaventura para denunciar que fue víctima de tortura por parte de un grupo paramilitar en Buenaventura comandado por un sujeto conocido por el alias de "Tabano". Dicho grupo paramilitar condujo bajo engaños al señor Ángel a un barrio de bajamar conocido como El Cristal, lugar con fuerte presencia y dominio paramilitar. Una vez allí es torturado física y psicológicamente, al atarlo de manos y piernas, y puesto a la intemperie encima de una embarcación tipo lancha durante 48 horas. Durante ese tiempo denunció que fue golpeado por los integrantes de ese grupo armado ilegal e incluso se turnaron para propinarle puños y puntapiés. También estos sujetos mientras golpeaban a Don Ángel, le dijeron que lo asesinarían y que le iban a hacer lo mismo a su familia. 


\subsubsection{Amenazas}

Las amenazas fueron personalmente, pasaban en un carro y me decían "hermanito póngase pilas que lo vamos a picar o se va de aqui'". 119

Luis Ángel Sinisterra Viveros, tras ser víctima de amenazas, decide acudir a la Personería de Buenaventura Valle del Cauca. Denunciando amenazas contra su vida y la de su familia por parte de grupos de autodefensas, el día veintiocho (28) de mayo de 2005. Al acudir a denunciar los hechos de amenazas lo único que pudo recibir fue una constancia expedida por el Personero Arlington Angulo Rentería ${ }^{120} \mathrm{y}$ una recomendación del mismo: "hermanito lo mejor que puede hacer es irse de aquí". Poco después, Sinisterra Viveros no tuvo otro camino que desplazarse de Buenaventura.

En el 2011 Don Ángel debió retornar a Buenaventura Valle del Cauca por las necesidades padecidas en Ibagué. Dos años después de su regreso decidió ir junto con su hermano Rolando, a un predio de su señor padre ubicado en la vereda La Gloria, ubicado en la comuna 12, zona rural de Buenaventura. Allí justo antes de llegar a su destino fue interceptado por un sujeto que responde al alias de "Enrique". El sujeto procede a recomendarles que no sigan averiguando por el predio de su señor padre y les informa que está siendo ocupado por Los Urabeños. Además les advierte que atentaría contra sus vidas de ser necesario.

Poco después un lugareño les dijo a los hermanos Sinisterra que "por allá podrían matarlos si seguían camino al predio", fue entonces cuando deciden no ir al predio de su padre. Luego Ángel Sinisterra decidió denunciar a alias "Enrique" ante la fiscalía de Buenaventura por el delito de amenazas. Estas amenazas quedaron plasmadas con el radicado No. 730016000444201305108 donde afirma el señor Ángel que hubo un error por parte de la señora fiscal del caso, al ubicarlo a él frente a su agresor. Un sujeto identificado como Enrique asistió a la citación de la Fiscalía, en donde negó todo señalamiento de ser el responsable de las amenazas contra el señor Ángel y su hermano Rolando. Además se rió e incluso lanzó insultos contra Sinisterra Viveros y su hermano. Esta diligencia terminaría sin arrojar resultado alguno que probara la responsabilidad del sujeto Enrique y el despojo del predio de La Gloria.

Don Ángel temiendo por su vida se desplazó forzadamente a la ciudad de Ibagué, acompañado de algunos familiares se fueron en bus y abandonaron la ciudad portuaria. Ya en Ibagué acudió a la Unidad Nacional de Protección (UNP), porque las amenazas continúan por parte del frente 21 de las FARC, ELN y las Autodefensas Gaitanistas de Colombia (AGC), y solicita medidas de protección, pero no recibió respuestas por parte de la UNP, es entonces donde decide instaurar una acción de tutela contra la Unidad Nacional de Protección, solicitando que:

\footnotetext{
119 Ángel Sinisterra, Entrevista 28 de marzo de 2017.

${ }^{120}$ Constancia expedida por el personero de Buenaventura Valle del Cauca de fecha 02 de julio de 2003.
} 
Se ordene a la accionada o a quien corresponda que de manera inmediata procedan a realizar las gestiones administrativas para que se disponga de manera ininterrumpida las medidas de protección que requiere en su calidad de líder de las comunidades afro y de víctimas del conflicto armado... ${ }^{121}$

En los hechos el señor Ángel afirmó que él siguió recibiendo amenazas contra su vida e integridad personal. El día 11 de febrero de 2016, durante una capacitación de su trabajo en la mesa de víctimas se encontraba en un hotel de la ciudad de Ibagué conocido como "Casa Morales", donde recibió un mensaje a su celular con la siguiente amenaza "Señor negro es declarado objetivo militar por el frente 21 de las FARC cuídese no queremos saber de usted ni su fundación". ${ }^{122}$

La parte accionada UNP, contesta la acción de tutela afirmando que hizo la articulación con fiscalía y policía metropolitana de Ibagué para darle respuesta a la solicitud de Don Ángel en un periodo de 30 días hábiles. Para terminar su contestación indica que se encuentra registrada la solicitud y su caso una orden de trabajo, mediante la cual se identificara el nivel de riesgo del accionante.

Ante dicha respuesta el Juzgado analiza que han pasado más de tres (3) meses y no hay respuesta alguna por parte de la UNP. Vulnerando de esta manera los derechos fundamentales a la integridad personal y a la vida del señor Ángel Sinisterra. Dado que la misión de la UNP, es ser la encargada de la prestación del servicio de protección a quienes el Estado por virtud de sus actividades, labores u oficios como el activismo de derechos humanos se encuentran en situación de riesgo extraordinario o extremo de sufrir daños contra su vida e integridad o la de su familia.

Por lo anterior el Juez decidió amparar los derechos fundamentales a la integridad personal y a la vida del señor Luis Ángel Sinisterra Viveros y ordenar al director de la UNP en máximo dos (2) meses proceda a expedir acto administrativo que determine el nivel de riesgo del accionante y en consecuencia se adopten las medidas de protección necesarias. 123

El día 10 de mayo de 2018, Don Ángel acudió a la Fiscalía de Ibagué para denunciar el delito de amenazas según el artículo 357 del código penal. Una vez allí indicó a la fiscalía que luego el día 03 de enero de 2018 al visitar Buenaventura recibió amenazas de muerte en el centro de la ciudad portuaria. En esta diligencia Ángel Sinisterra manifestó lo siguiente: "Se me acerca un sujeto que se identifica como alias "Chucho" me dice que por mi labor social, yo me iba a morir; por ser un informante de las autoridades nacionales e internacionales..."

\footnotetext{
121 Juzgado Décimo Administrativo del Circuito Judicial de Ibagué, 73001-33-40-010-2016-00123-00, 2016.

122 Juzgado Décimo Administrativo del Circuito Judicial de Ibagué, 73001-33-40-010-2016-00123-00, 2016.

${ }^{123}$ Juzgado Décimo Administrativo del Circuito Judicial de Ibagué, 73001-33-40-010-2016-00123-00, 2016.
} 
Además según Don Ángel, adujo que alias "Chucho" señaló que tiene otros dos sujetos en motocicletas listos para actuar. Y por eso Don Ángel no tuvo otra opción que huir del lugar e inmediatamente salir de Buenaventura.

En esta misma diligencia Don Ángel informó que cuando se dirigió a una reunión de la comunidad de afrodescendientes del Tolima los días 23 y 27 de marzo de 2018 en los municipios de El Espinal Tolima y Las Platas Huila, observó que era seguido por una persona. Por esta razón, el señor Ángel tuvo que suspender los viajes de trabajo a los diferentes lugares del territorio nacional.

Cuando salgo desde donde vivo, siempre sale una moto, o cuando llego a mi casa siempre llega un mismo carro. ${ }^{124}$

En esta misma diligencia rendida ante la Fiscalía de Ibagué, el señor Ángel Sinisterra solicitó las medidas de protección por ser líder social representante de la población afro a nivel departamental y nacional. Ante esta denuncia de amenazas y su solicitud de instaurar las medidas de protección al respecto no fueron atendidas y por ende el día 30 de mayo de 2018, por intermedio de un derecho de petición interpuesto ante fiscalía, solicitando el estado del trámite en que se encuentran las medidas de protección. La Fiscalía de Ibagué respondió mediante el oficio de radicación ORFEO 20180142336972 y HMP-201800025570_RAD. 730016099093201603829: “Se ordenó una nueva entrevista en cumplimiento del programa metodológico para aportar nuevas pruebas"125

El 02 de agosto de 2018, Don Ángel en representación de la Mesa Municipal de Ibagué, la Departamental de Víctimas del Tolima, del Comité de Justicia Transicional Departamental y ASFROVICTOL realizó una denuncia por amenazas. Esta fue hecha ante el coordinador de la mesa por medio de una llamada telefónica donde una persona se identifica como alias "Peluso" afirmando ser miembro del comando central de Águilas Negras ${ }^{126}$ y manifiesta lo siguiente: "Dígale a ese negro hijo de puta de Sinisterra no hace sino joder y montarla que se lo pasa metido en lo que no le importa, lo vamos a asesinar y tiene que renunciar a las mesas de víctimas" ${ }^{127}$. Ángel Sinisterra solicita a la fiscalía una ruta de protección para él y sus compañeros defensores de los derechos humanos y sustenta su solicitud con los siguientes fundamentos de derecho:

"Al auto 005 del 2009 y el 073 de 2014 prioridad de la comunidad Afro, el decreto 4912 del 26 de diciembre de 2011, capítulo 2, Estrategia, artículo 6, inciso 9 víctimas de violaciones a los derechos humanos e infracciones al derecho internacional humanitario, incluyendo dirigentes, líderes

\footnotetext{
${ }^{124}$ Fiscalía de Ibagué, $730016099093201803156,2018$.

${ }^{125}$ Fiscalía de Ibagué, HMP-2018-00025570, 2018.

${ }^{126}$ Las Águilas Negras son un grupo armado ilegal, disidente y heredero de Carlos Castaño. Su nombre es utilizado por otros comandos paramilitares para hacer sus atentados y amenazas contra civiles, abogados y líderes sociales.

${ }^{127}$ Fiscalía de Ibagué, TOLIM-GIT-No.2018140374012, 2018.
} 
representantes de organizaciones de la población desplazadas

o reclamantes de tierras en situación de riesgo extraordinario

o extremo". 128

Como se pudo evidenciar la vía judicial a la cual acudió el señor Ángel presenta dilación, demoras injustificadas e indiferencia. Poco es el resultado que arroja esta vía, poniendo en peligro la vida e integridad de Don Ángel.

\subsection{Vía Administrativa}

\subsubsection{Tortura}

Con respecto a este delito, Don Ángel afirma que las autoridades del Tolima le ofrecieron sus servicios profesionales pero afirmó que si bien existe un programa de atención a las víctimas este no tiene un enfoque diferencial étnico. Don Ángel solicitó entonces como líder social afrodescendiente a las autoridades que le brinden un profesional de su etnia, que sea él quien deba atenderle porque conoce su cultura y sus necesidades.

\subsubsection{Amenazas}

Como se mencionó en el capítulo anterior la Unidad Nacional de Protección (UNP), respondió a su solicitud el día 22 de septiembre de 2016 afirmando que "se efectuó un estudio de nivel de riesgo, el cual fue ponderado como Ordinario por el Grupo de Valoración Preliminar (...)" Este nivel de riesgo es un riesgo tolerable para personas que integran una comunidad. Nivel de riesgo ordinario, soportado por igual por quienes viven en sociedad. ${ }^{129}$ Ante ello, Don Ángel interpuso una acción de tutela la cual falló a su favor y también un incidente de desacato contra la UNP, como se mencionó anteriormente.

El 20 de febrero de 2018, la Unidad Nacional de Protección, responde a la solicitud de Don Ángel pero sin arrojar positivos resultados, por el contrario continuó con su nivel de riesgo ordinario.

Deberían hacer una ruta procuraduría especial para los líderes, sacar al líder de la zona insegura y dar un transporte seguro y digno para desplazarme.

Ángel Sinisterra, Entrevista junio de 2018.

\subsubsection{Desplazamiento Forzado}

Como se mencionó en capítulos previos, Luis Ángel Sinisterra fue víctima de desplazamiento forzado en Buenaventura Valle del Cauca, en dos oportunidades por grupos armados ilegales. A raíz de esos hechos tuvo que abandonar su casa en Buenaventura y un predio ubicado en La Gloria [zona rural de Buenaventura].

\footnotetext{
${ }^{128}$ Fiscalía de Ibagué, TOLIM-GIT-No.2018140374012, 2018.

${ }^{129}$ Corte Constitucional, Sala Tercera de Revisión, T-719, 2003.
} 
Por el abandono y despojo a manos de los grupos armados ilegales, que aún continúan operando en la zona, Ángel tuvo que acudir a la Unidad de Restitución de Tierras de manera independiente como reclamante de tierras. La URT le otorgó una constancia que registra sus bienes identificados mediante solicitudes No. ID 118960 y 169917 donde hace constar ambos predios el titular es el señor Luis Ángel Sinisterra Viveros con fecha: 201309-10. ${ }^{130}$ Estos dos predios se encuentran protegidos por la Unidad de Restitución de Tierras lo cual impide su ocupación y/o enajenación.

Posteriormente por intermedio de un derecho de petición, solicitando información del proceso de sus bienes el señor Ángel obtiene de la Unidad de Restitución de tierras la información de "los dos predios solicitados en restitución se encuentran en una zona donde no se configura la seguridad para que sea aplicada la política de restitución de tierras (...)" es decir según el concepto anterior cabe mencionar que la URT consulto al sector del ministerio de defensa quien afirma la existencia de inseguridad en la zona y por lo cual no se podrá realizar la restitución de tierras al señor Ángel Sinisterra. Además el oficio concluye comunicando que Don Ángel es el titular de los dos bienes en mención y estos están registrados en el Sistema de Registro de Tierras Despojadas y Abandonadas, Forzosamente.

Para el caso concreto el proceso de restitución de tierras del señor Ángel se encuentra activo en la etapa administrativa. Como es sabido Don Ángel tiene dos bienes inmuebles el primero de ellos una casa ubicada en el casco urbano de Buenaventura, la cual se encuentra en estudio formal del caso a la espera de la georeferenciazion del predio. Por su parte el segundo inmueble correspondiente al predio ubicado en la vereda La Gloria [Zona Rural de Buenaventura], se encuentra en la etapa administrativa en análisis previo, ya que se encuentra supendido puesto que no están dadas las garantías de seguridad en la zona.

Por lo anteriormente expuesto el señor Ángel esta a la espera que sus dos bienes inmuebles puedan ser inscritos en el registro de tierras despojadas y se pueda avanzar a la etapa judicial.

se encuentra activo y a la espera se encuentra Don Ángel quien tuvo que dejar su casa y el predio que le dejo su señor padre, por culpa de los grupos armados ilegales que operan en Buenaventura.

En cuanto al Registro Único de Victimas, el señor Ángel se encuentra registrado y se le reconocieron dos amenazas y en una ocasión le fue negado una de esas amenazas. También se le reconoció sus dos desplazamientos forzados de Buenaventura.

Don Ángel afirmó que un funcionario de esta entidad le dijo que le ayudaría así que le ofreció \$ 50.000.oo para un arriendo.

Aunque la vía administrativa avanza un poco más con respecto a la judicial, aún persiste la respuesta tardía y con resultados poco efectivos que garanticen los derechos al señor Luis Ángel Sinisterra Viveros.

${ }^{130}$ Unidad de Restitución de Tierras, DTTI1-201801306, 2018. 


\section{CAPÍtULO V}

\section{IMPACTOS}

El impacto es una colisión, es una huella, una marca e incluso un golpe anímico. Las violaciones a los derechos humanos afectan las emociones de las víctimas, ya sea directa o indirectamente. Para el Doctor en psicología Carlos Martín Beristaín el impacto es un grave hecho que afecta a las víctimas y lo describe de la siguiente manera:

El impacto de las violaciones puede describirse como una herida psicológica. Esa metáfora ayuda a ver que el daño se mantiene en el tiempo, y que el dolor de la gente no es algo que se pueda esconder debajo del tapete. (Martín, 2005, p.2) $)^{131}$

Los impactos por violaciones de derechos humanos no tienen una noción universal, porque dependen del contexto e incluso de la cultura a la que pertenece la víctima:

El impacto de las violaciones puede ser visto como un trauma, (...) sin embargo, este se produce en un contexto y moviliza significados que también son sociales, (...) También hay que tener en cuenta que esta explicación no es universal dado que, por ejemplo, en muchas culturas indígenas, el trauma no se considera como una herida, sino como la ruptura de un equilibrio con la comunidad, la naturaleza o los ancestros. (Martín, 2008, p.32) ${ }^{132}$

Los impactos ocasionan daños materiales, o inmateriales como también morales y psíquicos los cuales afectan los proyectos de vida de las víctimas. El daño según Henao J (2015), se refiere a "toda afrenta a los intereses lícitos de una persona, trátese de derechos pecuniarios o de no pecuniarios, de derechos individuales o de colectivos, que se presenta como lesión definitiva de un derecho o como alteración de su goce pacífico”(p.1). ${ }^{133}$

El Tribunal Europeo de Derechos Humanos define el daño material y el daño moral de la siguiente manera, el primero "son, las pérdidas realmente sufridas como consecuencia

\footnotetext{
${ }^{131}$ CEJIL (2005) Debates sobre los Derechos Humanos y el Sistema Interamericano. Recuperado de https://cejil.org/es/revista-cejil-ano-ino-1-debates-derechos-humanos-y-sistema-interamericano

132 Instituto Interamericano de Derechos Humanos (IIDH). (2008). Diálogos Sobre la Reparación; Experiencias en el Sistema Interamericano de Derechos Humanos. Recuperado de https://www.iidh.ed.cr/IIDH/media/2120/dialogo_reparacion_tomo1.pdf

${ }^{133}$ J. C. Henao, "Las formas de reparación en la responsabilidad del Estado: hacia su unificación sustancial en todas las acciones contra el Estado", Revista de Derecho Privado, Universidad Externado de Colombia, n. ${ }^{\circ}$ 28, enero-junio de 2015, pp. 277-366. DOI: 10.18601/01234366.n28.10
} 
directa de la presunta violación" y el daño moral como "(...) la angustia, incomodidad, disgusto e incertidumbre resultantes de una violación (...)."134

A su vez, la Corte Interamericana de Derechos Humanos presenta una noción del daño moral y como es su eventual reparación:

Aquellos efectos nocivos de los hechos del caso que no tienen carácter económico o patrimonial y no pueden ser tasados, por ende, en términos monetarios. El mencionado daño moral puede comprender tanto los sufrimientos y las aflicciones causados a las víctimas directas y a sus allegados, como el menoscabo de valores muy significativos para las personas y otras perturbaciones que no son susceptibles de medición pecuniaria. Es una característica común a las distintas expresiones del daño moral el que, no siendo posible asignárseles un preciso equivalente monetario, sólo puedan, para los fines de la reparación integral a las víctimas, ser objeto de compensación, y ello de dos maneras. En primer lugar, mediante el pago de una suma de dinero o la entrega de bienes o servicios apreciables en dinero, que el Tribunal determine en aplicación razonable del arbitrio judicial y en términos de equidad. $Y$ en segundo lugar, mediante la realización de actos u obras de alcance o repercusión públicos, que tengan efectos como la recuperación de la memoria de las víctimas, el restablecimiento de su dignidad, la consolación de sus deudos o la transmisión de un mensaje de reprobación oficial a las violaciones de los derechos humanos de que se trata y de compromiso con los esfuerzos tendientes a que no vuelvan a ocurrir. (Corte Interamericana de Derechos Humanos, 2001, párr.84 ${ }^{135}$ )

En la doctrina el daño moral o también llamado daño extrapatrimonial, presenta nociones no tan alejadas a las anteriores definiciones de ámbito legal, como lo es para los hermanos Mazeaud (1960) citado por Mendoza (2014, p.51), "daño moral como aquel que "constituye un atentado contra un derecho extrapatrimonial, o sea, no pecuniario." El daño moral, se caracteriza entonces como un agravio moral que no tiene carácter pecuniario y el cual atenta contra los intereses morales, como el honor, la consideración social o la vida misma.

Los perjuicios morales se caracterizan según Mendoza (2014) como "aquellos que atentan contra la parte social del patrimonio moral y los que violentan la parte afectiva del ser

\footnotetext{
${ }^{134}$ European Court of Human Rights. Caso Comingersoll, S.A. Contra Portugal. Sentencia 35382/97 del 06 de abril de 2000. Punto 2 artículo 41 del Convenio.

135 Corte Interamericana de Derechos Humanos. Caso de Los "Niños de la Calle" (Villagrán Morales y Otros) vs Guatemala. (Reparaciones y Costas). Sentencia del 26 de Mayo de 2001.Párr.84.
} 
humano en su esfera personalísima". ${ }^{136}$ Adicionalmente también las víctimas sufren otros tipos de daño que afectan su patrimonio y sus bienes como lo son los daños materiales.

\subsection{Daño Material}

Para la Corte Interamericana de Derechos Humanos el daño material se define como "la pérdida o detrimento de los ingresos de las víctimas, los gastos efectuados, con motivo de los hechos y las consecuencias de carácter pecuniario que tengan un nexo causal con los hechos del caso (...)."137

Según Maciá (s.f), el daño material se caracteriza por provocar "una disminución de utilidad que se reintegra o se repara con dinero o con bienes intercambiables por dinero" (p.2). ${ }^{138}$

Mientras que la noción de daño material según la Corte Constitucional se refiere a "la pérdida o detrimento de los ingresos de las víctimas, los gastos efectuados con motivo de los hechos y las consecuencias de carácter pecuniario que tengan un nexo causal con los hechos del caso." 139

En el caso sub júdice, Don Ángel fue despojado de dos bienes materiales por parte del conflicto armado. Los bienes consistentes en una casa y un lote. El primer bien inmueble ubicado en la ciudad Buenaventura, y el segundo ubicado en la vereda La Gloria zona rural de Buenaventura el cual fue ocupado por el grupo delincuencias conocido como "Los Urabeños".

\subsection{Daño Psíquico}

El daño psíquico por su parte tiene su origen en el discurso jurídico y no en el discurso psicológico. El perito tendrá que hacer un examen de los síntomas resultantes del hecho traumático para determinar si hubo o no conformación patológica y por lo tanto daño psíquico. ${ }^{140}$

Además este presenta dos clases. Lesión psíquica que hace referencia a una alteración clínicamente significativa que afecta en mayor o menor grado la adaptación de una persona

\footnotetext{
${ }^{136}$ Mendoza, L. (2014). La Acción Civil del Daño Moral. (pp. 51-52).235 Ed. México: UNAM.

137 Calderón, J. (2013). La Reparación Integral en la Jurisprudencia de la Corte Interamericana de Derechos Humanos: Estándares Aplicables al Nuevo paradigma Mexicano. Recuperado de: http://www.corteidh.or.cr/tablas/r33008.pdf

${ }^{138}$ Maciá, R. (s.f). La Dualidad del Daño Patrimonial y del Daño Material. Revista de Responsabilidad Civil y de Seguro. [21-32]. DOI: http://asociacionabogadosrcs.org/doctrina/rc36doctrina2.pdf

${ }^{139}$ Corte Constitucional de Colombia. Sentencia C-344/17 del 24 de mayo de 2017.

${ }^{140}$ Puhl, Stella M.1; Izcurdia, M. de los Ángeles2; Oteyza, Gabriela2; Gresia Maertens, Beatriz H. (2017). Peritaje Psicológico y Daño Psíquico. facultad de psicología - uba / secretaría de investigaciones / anuario de investigaciones / volumen xxiv. [p.253]. doi: http://ppct.caicyt.gov.ar/index.php/anuinv/article/download/11284/45454575758319
} 
en los distintos ámbitos de su vida personal, social, familiar o laboral. La otra forma, es la secuela psíquica que se refiere a la estabilización y consolidación de esos desajustes psicológicos. (Echeburúa, De Corral y Amor (2004) citado por Muñoz (2013).

\subsubsection{Daño Psíquico por Falta de Respuesta Estatal}

El señor Ángel Sinisterra como se ha mencionado en capítulos anteriores, padeció una serie de hechos que violaron sus derechos humanos a raíz del conflicto armado interno colombiano. Adicionalmente, sufrió a causa de las posteriores actuaciones u omisiones de las autoridades estatales frente a los hechos vividos. Este proceder del Estado vulnera el derecho a la integridad psíquica y moral no solo de Don Ángel sino además de sus familiares quienes a su vez pueden ser víctimas ${ }^{141}$.

\subsection{Daño al Proyecto de Vida}

El proyecto de vida para Irriberri (s.f) "es una herramienta que pretende apoyar el crecimiento personal, identificando las metas que deseamos conseguir y reconocer las capacidades que poseemos; este plan evita la dispersión y el desperdicio de tiempo y de nuestros recursos (p.1)."142

Para la Corte Interamericana de Derechos Humanos, el proyecto de vida es consustancial del derecho a la existencia, y requiere para su desarrollo condiciones de vida digna, de seguridad e integridad de la persona humana. ${ }^{143}$

La Corte a su vez expresó en el caso de Loayza Tamayo vs Perú que:

El daño al proyecto de vida debe ser integrado al universo conceptual de las reparaciones bajo el artículo 63.1 de la Convención Americana. Ahí expresamos que El proyecto de vida se encuentra indisolublemente vinculado a la libertad, como derecho de cada persona a elegir su propio destino. (...) El proyecto de vida envuelve plenamente el ideal de la Declaración Americana [de los Derechos y Deberes del Hombre] de 1948 de exaltar el espíritu como finalidad suprema y categoría máxima de la existencia humana. (Corte

\footnotetext{
${ }^{141}$ (Corte Interamericana de Derechos Humanos, caso Baldeón García vs Perú, párr. 128, 2006); (Corte Interamericana de Derechos Humanos, caso Masacre de Mapiripam vs Colombia, supra párrs. 96.141, 96.145 y 96.175, 2006); (Corte Interamericana de Derechos Humanos, caso Lopez Alvarez vs Honduras, nota 6, párr. 119, 2006); (Corte Interamericana de Derechos Humanos, caso Gómez Palomino vs Perú, nota 1, párr. 144 y 146, 2005).

142 Irriberri A. (s.f). Que es un Proyecto de Vida. [p.1]. doi: https://moodle2.unid.edu.mx/dts_cursos_mdl/lic/AE/VC/AM/AF/proyecto_de_vida_nuevo.pdf

${ }^{143}$ Corte Interamericana de Derechos Humanos. Caso de Los "Niños de la Calle" (Villagrán Morales y Otros) vs Guatemala. (Reparaciones y Costas). Sentencia del 26 de Mayo de 2001.Párr.8.
} 
Interamericana de Derechos Humanos Caso Loayza Tamayo

Vs. Perú Sentencia de 17 de septiembre de 1997 (Fondo). ${ }^{144}$

Por lo tanto para la Corte el daño al proyecto de vida tiene una afectación en la salud física y psíquica de las víctimas, ya sea por la angustia y desesperanza que se producen por la inoperancia o la impunidad en las autoridades competentes para resarcir este tipo de daño. ${ }^{145}$

\section{Caso Concreto}

Las violaciones de derechos humanos y las infracciones al derecho internacional humanitario pueden provocar en las víctimas daños materiales y daños inmateriales o morales, Consistentes en lesiones físicas y psíquicas que afectan no solo a las victimas también a sus familiares y amigos, quienes también sufren de alguna u otra manera estos daños.

Los daños morales dejan huellas en muchos casos imborrables porque afectan el patrimonio moral del ser humano y requieren de una especial e integral atención. A continuación, se relatan las emociones y sensaciones vividas por Don Ángel y su amigo el señor Juan*. ${ }^{146}$

Las víctimas al no recibir las ayudas del Estado, sienten impotencia y desesperanza. Ángel Sinisterra desde que era un joven ha observado cómo la desilusión acompaña a los habitantes de su natal Buenaventura, a lo largo de su vida. Un municipio que pese ser rico en recursos naturales, poseer el puerto más importante de Colombia y lamentablemente ser uno de los municipios donde se cometen mayores violaciones a los derechos humanos e infracciones al derecho internacional humanitario, las ayudas del gobierno no llegan o estas no son eficaces, lo cual alimenta la desesperanza, la angustia y la pobreza entre sus habitantes.

En el caso de Don Ángel, la tortura es una de las formas más violentas y degradantes que atentan contra la dignidad de las personas. Don Ángel recuerda cómo quedó marcado de por vida el haber sido víctima de tortura por los paramilitares.

La tortura física duraron dos días y psicológica todo un tiempo

Ángel Sinisterra, Entrevista 25 de agosto de 2018.

El señor Ángel incluso recuerda a quien fue uno de sus victimarios alias "Tabano".

Era un pelado joven, de estatura mediana y medio trigueño.

\footnotetext{
${ }^{144}$ Corte Interamericana de Derechos Humanos. Caso Loayza Tamayo Vs. Perú Sentencia de 27 de noviembre de 1998 (Reparaciones y Costas). Párr.147.

145 Corte Interamericana de Derechos Humanos. Caso Masacres de El Mozote y lugares aledaños vs. El Salvador. sentencia de 25 de octubre de 2012 (Fondo, Reparaciones y Costas) Párr.305. Y Corte Interamericana de Derechos Humanos. Caso Gomes Lund y Otros ("Guerrilha Do Araguaia") vs. Brasil. Sentencia de 24 de noviembre de 2010 (Excepciones Preliminares, Fondo, Reparaciones y Costas). Párr.307.

$146 *$ El nombre fue cambiado para garantizar y preservar la integridad de la persona.
} 
Ángel Sinisterra, Entrevista 25 de agosto de 2018.

Alias "Tabano" sería el comandante a cargo de esa cuadrilla paramilitar que sometió al señor Ángel a la tortura. Don Ángel además recuerda cómo eran el resto de sus agresores.

En las víctimas de graves violaciones a los derechos humanos y al derecho internacional humanitario, sus proyectos de vida se ven afectados drásticamente, impidiendo alcanzar sus metas, truncando sus anhelos y terminando prematuramente con sus planes de vida, ya sean de manera personal y/o colectiva. Ángel Sinisterra perdió su proyecto de vida junto con el de su familia e incluso perdió su identidad.

Duro, fracasado por completo porque la familia mía se desintegró, cada uno estamos por un lado y el proyecto de vida mío no sé hasta dónde voy a llegar, porque yo perdí una estabilidad que tenía de sostener a mi familia y sacarla adelante con el trabajo que yo estaba haciendo en mi región. Perdí mi identidad, perdí mi cultura, perdí mi tierra y se encuentra usted en una tierra ajena donde su cultura no prevalece, está olvidada acá.

Ángel Sinisterra, Entrevista 25 de agosto de 2018.

No solo afecta el proyecto de vida del señor Ángel y los de su familia, sino también afecta emocionalmente la forma para relacionarse con las demás personas y su entorno social. Como el aislamiento social, desconfianza, paranoia, y se retoman son las consecuencias generadas por los hechos violentos.

Yo mantengo desconfiado con todo mundo por lo que sucedió y por lo que está sucediendo ahora contra los líderes y lideresas. Yo mantengo desconfiado con todos, hasta con los mismos compañeros que hacemos parte de las mesas de víctimas. Porque hay no se sabe quién es quién y puede haber gente infiltrada. Yo de vez en cuando me guardo cosas y no las expreso porque no se el impacto que vaya tener, entonces mejor me las guardo. Porque mi temperamento es un temperamento muy fuerte, entonces mejor me guardo las cosas. Yo de vez en cuando yo llego y me aislo me hago en un sitio solo. Me llegan momentos muy nostálgicos.

Ángel Sinisterra, Entrevista 25 de agosto de 2018.

Las víctimas quieren volver a su estabilidad emocional, a su hogar, a reencontrarse con sus familias y lo que más desean es que todo pudiera volver a ser como antes. Don Ángel anhela día tras día que todo pudiera ser como antes, como cuando él estaba en Buenaventura y junto a su familia.

Añoro mucho mi ciudad, mi municipio donde está mi familia, mis amigos de la infancia, donde yo tenía mi trabajo, donde no pasaba necesidades como las estoy pasando ahoritica, volver a reunir a mi familia como la tenía antes y esos son muchos los recuerdos nostálgicos.

Ángel Sinisterra, Entrevista 25 de agosto de 2018. 
Las víctimas de desplazamiento forzado como Don Ángel que se encuentran en territorios ajenos donde hallan sentimientos como impotencia, inseguridad, desesperanza y no logran una solución.

Siento bastante impotencia cuando yo hago un reclamo, cuando yo le exijo a un secretario que porque no son cumplidos, su negligencia y la del Estado contra nosotros las víctimas. Inseguridad si se siente, bastante claro. En el momento que uno se levanta de la cama se siente inseguro.

Ángel Sinisterra, Entrevista 25 de agosto de 2018.

Por si fuera poco, a las víctimas de violaciones de derechos humanos e infracciones al derecho internacional humanitario a menudo quedan con padecimientos psicológicos y fisiológicos. Enfermedades que aquejan a las víctimas como al señor Ángel quien narra sus patologías.

Yo soy hipertenso y el Estado no ha hecho nada. Se siente uno tensionado y estresado porque cuando llega un día de que usted no puede salir a una diligencia por el factor dinero, por el factor de amistad y factor de comunicación. El estrés si me molesta por la situación monetaria y porque estoy en una tierra ajena porque si estuviera en mi departamento no tendría problemas, porque uno sabe cómo moverse allá.

Ángel Sinisterra, Entrevista 25 de agosto de 2018.

Otro problema producto de los hechos, es que se presentan inconvenientes dentro de las relaciones afectivas de la familia de las víctimas.

Con los hijos ya grandes porque a raíz del desplazamiento hemos tenido conflictos porque perdimos la casa, hemos perdido cosas y entonces los hijos mantienen reprochando eso. Pero como dice la cosa, eso no está en manos mías sino cuestión del Estado que no lo protegió. He tenido desintegración familiar y está bastante dura.

Ángel Sinisterra, Entrevista 25 de agosto de 2018.

Luis Ángel afirma que el Estado no le ha ayudado cumpliendo lo estipulado en las leyes pese a sus padecimientos, junto a los de su familia. Como por ejemplo Don Ángel, solicitó que se le devolviera su vivienda y un lote que perdió y un proyecto productivo. Pese a que Don Ángel es líder social, pertenece a una comunidad étnica vulnerable y trabaja con la defensa y promoción de los derechos humanos.

La respuesta del Estado es jmala, mala! el Estado no ha hecho nada, por eso la Corte declaró inconstitucionalmente la protección contra la población étnica como afros e indígenas en el auto 266 de agosto de 2017, el Estado ha nosotros no nos ha protegido nada ni ha resarcido los derechos que perdimos. Nosotros como víctimas del conflicto es este el problema más duro que hay, el económico. Hermano ya llevo como 7 años que no tengo servicio de salud.

Ángel Sinisterra, Entrevista 25 de agosto de 2018. 
De mala en peor, porque como es que para los paras hubo unas cosas, pa' la guerrilla hubo cosas y pa' nosotros que fuimos las víctimas que ha pasado? hay esta.

Juan, Testimonio 14 de noviembre de 2018.

Por parte de la UAO de la unidad de víctimas, no hay ayudas no hay nada.

Juan, Testimonio 14 de noviembre de 2018.

La situación que deben soportar las víctimas es la de encontrarse con barreras e impedimentos que dificultan su acceso a la justicia y los servicios del Estado. Produciendo el desespero, de ver como la situación en vez de mejorar empeora.

Me angustio cuando las cosas no se dan. Me angustio cuando van pasando los años y meses, y las cosas no mejoran, no se solucionan. Porque entre más días más peor vamos nosotros. De ver las víctimas salir del problema que tienen y como que las están hundiendo más. Porque la vaina de víctimas es como una caja menor para el Gobierno, las víctimas las tienen no más de figuras, nada más. He encontrado bastantes barreras porque varias veces gente cuando uno se expresa, opinan de nosotros sin conocer nuestra cultura.

Ángel Sinisterra, Entrevista 25 de agosto de 2018.

Don Ángel siente desesperanza a raíz de que los hechos que soporto no son lo peor sino la dificultades después de lo vivido pueden llegar a ser igual o peor. En lo que se refiere a la débil ayuda estatal, la estimación, el rechazo y la falta de oportunidades generan una desilusión e incredulidad de las víctimas hacía con el Estado.

En este momento estoy bastante infeliz porque no estoy reunido con mis hijos, con mis familiares. En este momento estoy solo, entonces es una infelicidad, soy una persona sola. Sí, hay desesperanza es que yo me pongo a analizar la situación y yo no veo por donde se van a solucionar los problemas. Es que no lo veo, porque entre más días pasan es peor, porque gobierno viene gobierno pasa y no hay un proyecto de solución para las víctimas no hay.

Ángel Sinisterra, Entrevista 25 de agosto de 2018.

No ha hecho nada, una ayuda nos la dan cada año o sea cada año comemos, imagínese.

Juan, Testimonio 14 de noviembre de 2018. 


\section{CAPÍTULO VI}

\section{AFRONTAMIENTOS}

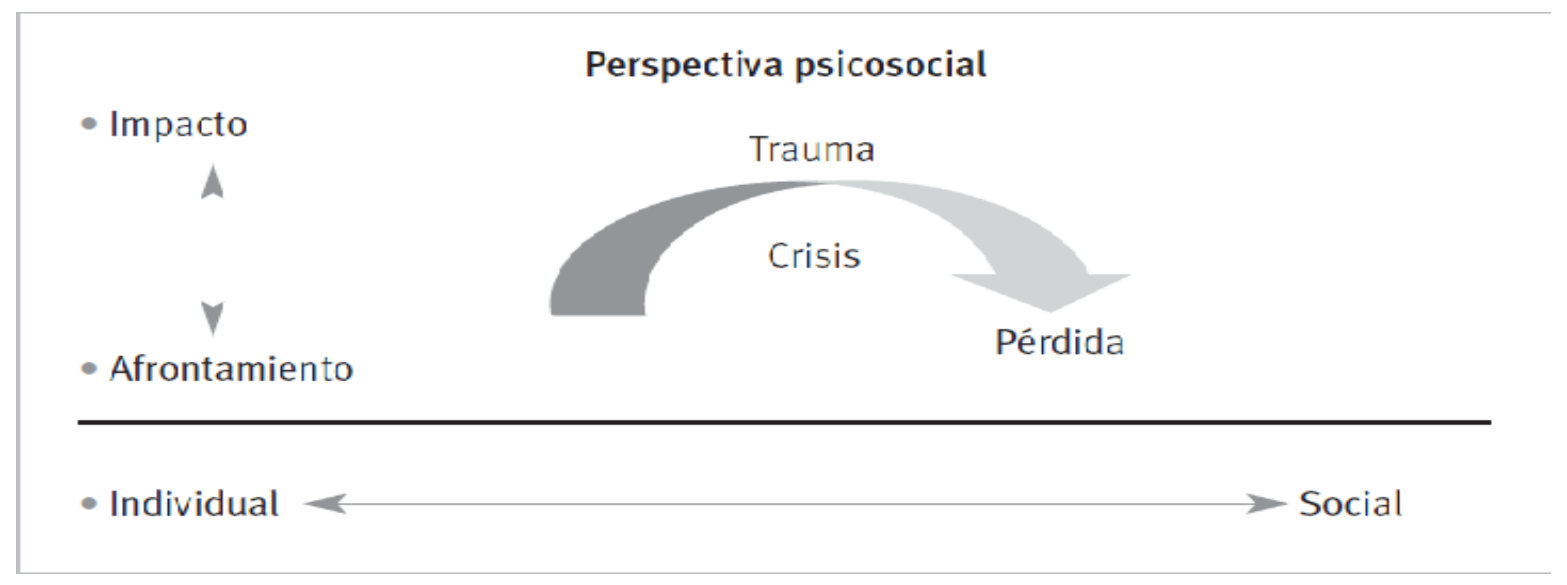

Gráfico 10. Martín, C. (2008) Diálogos Sobre la Reparación; Experiencias en el Sistema Interamericano de Derechos Humanos. [Cuadro]. Recuperado de https://www.iidh.ed.cr/IIDH/media/2120/dialogo_reparacion_tomo1.pdf

El afrontamiento es un "conjunto de esfuerzos conductuales y cognitivos que realiza el individuo para hacer frente a las situaciones estresantes, así como para reducir el estado de malestar que produce el estrés." 147

Desde un enfoque psicosocial el afrontamiento o también conocido como "Coping ${ }^{148 \text { " es }}$ aquel proceso comportamental frente a los cambios de la vida cotidiana. Para Folkman y Lazarus (1985) citados por Botero y Páez (2013), "el afrontamiento son los rasgos temperamentales y patrones con los cuales una persona responde ante los cambios en su vida cotidiana" ( p.2). ${ }^{149}$

El afrontamiento se presenta en dos clases de acuerdo con Botero y Páez (2013), "puede ser adecuado o positivo, cuando se busca una solución activa del problema. El afrontamiento puede ser de huida o negación esté basado en emociones y tiende a ser ineficaz y genera problemas secundarios a nivel personal y social" (p.2). ${ }^{\mathbf{1 5 0}}$

Para el Doctor Carlos Martín Beristaín, el afrontamiento es lo que las personas hacen para tratar de enfrentar las pérdidas de seres queridos o vínculos significativos. ${ }^{151}$

\footnotetext{
147 Clínica Universidad de Navarra (CUN). (2019). Diccionario Medico. Recuperado de https://www.cun.es/diccionariomedico/terminos/afrontamiento

${ }^{148}$ Termino inglés para referirse algunas veces al enfrentamiento.

149 Botero, J., Páez E. (junio de 2013). La Resiliencia y el Afrontamiento Positivo: Conceptos Atados. Caminos para la Resiliencia. Recuperado de http://www.udea.edu.co/wps/wcm/connect/udea/2f56b608-5bdc-44c5-a78a83298c5f54ea/BoletA\%CC\%83\%C2\%ADn+3_Afrontamiento+y+Resiliencia.pdf?MOD=AJPERES\&CVID=lglruPA

${ }^{150}$ IDEM

151 Instituto Interamericano de Derechos Humanos (IIDH). (2008). Diálogos Sobre la Reparación; Experiencias en el Sistema Interamericano de Derechos Humanos. Recuperado de https://www.iidh.ed.cr/IIDH/media/2120/dialogo_reparacion_tomo1.pdf
} 
Según Martín Beristaín, las estrategias de afrontamiento que utilizan las víctimas en contextos de terror es la tendencia a:

"la inhibición y al silencio ha sido muy frecuente en países como Colombia, Guatemala o El Salvador; allí la estrategia de terror en el conflicto armado interno llevó a la parálisis y a la desconfianza extrema como mecanismos de protección. Sin embargo, la inhibición a pesar de que puede ser una opción en un contexto hostil tiene un coste emocional y un impacto en la salud. El proceso de litigio ofrece, en ocasiones, un espacio y un sentido para afrontar algunos de esos impactos, especialmente si cuenta con acompañamiento". (Martín, 2008, p.121) $)^{152}$

En el caso Rosendo Cantú vs México ${ }^{153}$, se puede observar el afrontamiento de la víctima por obtener justicia, luchando contra las barreras idiomáticas, la revictimización por parte de las autoridades, algunos miembros de su comunidad indígena e incluso su propia familia, su afrontamiento fue por encontrar la justicia. También, en el caso Campo Algodonero vs México ${ }^{154}$ donde los familiares tuvieron que afrontar una lucha contra la impunidad y el rechazo de las autoridades.

En el caso concreto, el señor Luis Ángel Sinisterra Viveros, pese al sufrimiento vivido junto a su familia a raíz de los daños materiales y morales del conflicto armado interno en Buenaventura y a las dificultades por las que atraviesa aún, su espíritu de líder social continúa intacto desde que era un joven bonaverense emprendió una misión de representar a quienes más lo necesitan. El señor Ángel aprendió de lo vivido para superarse y emprender su labor social.

No, pues la valentía y mis conocimientos me toco para enfrentarlo. Del mismo miedo me dio valentía para enfrentar todos los hechos.

Ángel Sinisterra, Entrevista 25 de agosto de 2018.

Pero Don Ángel necesito de voluntad que le permitiera ejercer su labor como líder social, dado el riesgo que representa ejercer esta profesión tanto para él como para su familia quienes se preocupan por su bienestar pese a la distancia. Así mismo, el señor Ángel se dedicó a formarse para su profesión como líder, asistiendo a capacitaciones, trabajando en conjunto con las autoridades y dirigiendo su propia asociación.

\footnotetext{
152 Instituto Interamericano de Derechos Humanos (IIDH). (2008). Diálogos Sobre la Reparación; Experiencias en el Sistema Interamericano de Derechos Humanos. Recuperado de https://www.iidh.ed.cr/IIDH/media/2120/dialogo_reparacion_tomo1.pdf

${ }^{153}$ Corte Interamericana de Derechos Humanos. Caso Rosendo Cantú y Otra Vs. México. Sentencia de 31 de agosto de 2010. (Excepción Preliminar, Fondo, Reparaciones y Costas). Párr.128.

${ }^{154}$ Corte Interamericana de Derechos Humanos. Caso Campo Algodonero vs México. Sentencia de 16 de noviembre de 2009. (Excepción Preliminar, Fondo, Reparaciones y Costas). Párr. 412-420.
} 
Claro es que primero que todo, sea lo que me sucedió o no me hubiera sucedido yo siempre me encomiendo al Señor.

Si yo busco bastante información, yo soy un tipo que me mantengo buscando esa información, me gusta leer, tener mucho conocimiento para cuando yo voy a hacer un reclamo yo tenga base y sustento con algo.

Ángel Sinisterra, Entrevista 25 de agosto de 2018.

La resiliencia en las víctimas de violaciones tan graves como las de los derechos humanos e infracciones del derecho internacional humanitario es una alternativa para continuar con sus vidas y poder dejar de cierta manera atrás los estragos y cicatrices del conflicto.

Yo desde muy joven me sentí representado en reclamar los derechos de las personas indefensas, de representarlas, es que yo viendo en el transcurso de mi juventud yo veía que había personas que no sabían reclamar y no sabía dónde ir y yo me daba la idea de eso de acompañarlos, de ayudarlos y ser líder nació conmigo.

Hago política en la defensa de los derechos humanos del pueblo afro y yo sé que eso es un compromiso.

Ángel Sinisterra, Entrevista 25 de agosto de 2018.

En muchos casos las víctimas se sienten juzgadas por las demás. Por esta razón, muchas de esas víctimas guardan silencio para evitar ser rechazadas, estigmatizadas y revictimizadas por las demás personas en una sociedad.

Si oculto sentimientos porque no sé cómo lo va tomar la persona o de burlarse de uno porque hay personas que son felices con el dolor de otros.

No me gusta mucho hablar de eso.

Ángel Sinisterra, Entrevista 25 de agosto de 2018.

Es el Estado a quien le corresponde garantizar las ayudas a las víctimas y hacer todo para que puedan reintegrarse a la sociedad. Pero son muchos los casos donde el Estado se queda corto impidiendo la atención que requieren las víctimas. Don Ángel concluye que las ayudas del Estado no funcionan porque no tienen una solución y una finalidad como es su caso donde tiene que dedicar mucho tiempo solicitando que le ayuden, pero la respuesta estatal es tardía y poco eficaz.

Sí, me hicieron un programa que hace el gobierno pero eso no más es por encimita, eso queda en las nubes porque el funcionario que manda al psicólogo quieren que le cuenten todo lo que sucedió y nunca le da una solución solamente es como cumplir un contrato y listo.

Ángel Sinisterra, Entrevista 25 de agosto de 2018.

Dada la gravedad de los hechos las víctimas presentan desconfianza y se convierten en personas que se aíslan de las demás, reprimen sentimientos y guardan silencio evitando 
hablar de lo sucedido. Muchas de las víctimas del conflicto armado buscan apoyo en las instituciones del Estado pero al no recibir su respaldo acuden a fundaciones, asociaciones y organizaciones no gubernamentales de índole nacional e internacional. El señor Ángel creó su propia asociación identificada como la Asociación Afro Víctima del Conflicto del Tolima (ASFROVICTOL). En ella, Don Ángel representa y asesora a las víctimas afrocolombianas del conflicto armado en el Tolima.

Si ahoritica estamos más integrados, ahorita yo hago parte de un espacio nacional, soy presidente y representante legal de la asociación ASFROVICTOL, la cual nació en el departamento del Tolima y en la ciudad de Ibagué porque cuando llegué como víctima del conflicto aquí a Ibagué me encontré que muchos afros estaban en los semáforos y en las calles pidiendo. Y cuando iban a reclamar sus derechos pues no sabían entonces me di en la tarea de recogerlos, los organizamos para reclamar nuestro derecho como colectivo que tiene que ver el Municipio y el Departamento en cuestión de grupos étnicos víctimas porque nosotros tenemos unos decretos ley como el 2635, que es el que nos rige a nosotros y acá en este Departamento no está cumpliendo. Entonces desde ahí nació la asociación ASFROVICTOL.

Ángel Sinisterra, Entrevista 25 de agosto de 2018.

El señor Ángel como muchas víctimas luego de lo sucedido es como un punto de partida para seguir adelante y continuar con sus vidas. En el caso de Sinisterra Viveros de cierta manera lo vivido lo ha fortalecido y llenado de más motivos para seguir. Él como muchos ha tenido problemas, ha padecido necesidades, soportado la indiferencia tanto del Estado como de la sociedad misma, pero continúa con su labor de líder social a raíz de los mismos hechos vividos en el pasado.

Sí, eso tiene sus cosas buenas y sus cosas malas. Cosas buenas he crecido me he dado a conocer a nivel nacional, por las redes, me conocen más, valorizan mi trabajo, me han dicho que gracias a la función mía en el Tolima ya los afros estamos saliendo adelante, se les reconocen cosas. Claro que no está del todo bien, porque todavía hay falencias pero si hay un crecimiento hay más crecimiento que cosas malas. Cosas malas que trajo esto, como la discriminación, la estigmatización, la violación de nuestros derechos por desconocimiento de los funcionarios (...)

Ángel Sinisterra, Entrevista 25 de agosto de 2018.

Don Ángel plantea que una forma de afrontar este problema es reconociéndolo y dándolo a conocer a los demás. Afirma, que la ignorancia y el desconocimiento de los hechos que sufrieron las víctimas se deben dar a conocer para generar conciencia en la sociedad y solidarizar los unos con los otros. Principalmente, plantea el señor Ángel que se conoce muy poco sobre las víctimas y aún menos cuando son pertenecientes a grupos étnicos, a raíz de la poca educación e información sobre el tema.

Porque los funcionarios piensan que la raza indígena y la raza afro no existen por el desconocimiento. Pasaron por unas universidades, por planteles educativos pero nunca les 
hablaron de eso, porque como hace falta la cátedra étnica en los planteles para que los muchachos desde la primaria vayan sabiendo cual es la población étnica y cuáles son los derechos y todo.

Ángel Sinisterra, Entrevista 25 de agosto de 2018.

De acuerdo a lo anterior, Don Ángel presentó un afrontamiento positivo, buscando siempre una solución que le ayudara a superar el sufrimiento padecido. Su profesión como líder social afrodescendiente es el medio que adoptó para afrontar el estrés y las angustias producidos por los hechos vividos, brindando asesoría y representando a las demás víctimas del conflicto armado. El señor Ángel prefirió denunciar lo que le pasó para que su historia se conociera, con el fin de evitar que a más personas corran con el mismo destino. 


\section{CAPÍTULO VII \\ MEDIDAS DE REPARACIÓN}

Las medidas de reparación son el reconocimiento que hace el Estado a las víctimas por su constante resistencia ante los hechos ocurridos que ocasionaron daños materiales y morales a las víctimas y familiares de los conflictos armados. El Estado a través de medidas que buscan prevalecer sus intereses y restablecer sus derechos.

Según el Alto Comisionado para la Paz (s.f.), "las medidas de reparación deben tener en cuenta las distintas experiencias, impacto diferencial y condiciones particulares de las personas. Para que la reparación sea efectiva, se asegurará una fuerte participación de las víctimas en las distintas medidas de reparación". ${ }^{155}$

La reparación es volver las cosas al estado anterior o compensar las cosas como estaban antes del suceso. Según Henao (2015) la reparación es "la manera como el responsable cumple la obligación de reparar asegurando a la víctima el retorno al status quo ${ }^{156}$ ante al acaecimiento del daño" (p.2). ${ }^{157}$

Para De Greiff (s.f), las reparaciones son "todas aquellas medidas que se pueden adoptar para resarcir los diversos tipos de daño que pueden haber sufrido las víctimas como consecuencia de ciertos crímenes (p.409)."158

En los principios rectores de la ONU, establecen como es una reparación adecuada, la cual debe ser efectiva, rápida y que promueva la justicia remediando las claras violaciones a las normas internacionales de derechos humanos o infracciones al derecho internacional humanitario. La reparación tiene que ser proporcional al daño sufrido y los Estados repararan a las víctimas conforme a la normatividad interna y a las obligaciones de carácter internacional. ${ }^{159}$

\footnotetext{
${ }^{155}$ Oficina del Alto Comisionado para la Paz. (s.f) ABC Medidas de Reparación Integral para la Construcción de Paz. Recuperado de http://www.altocomisionadoparalapaz.gov.co/Documents/informes-especiales/abc-del-proceso-de-paz/abc-medidas-reparacion-integralpara-construccion-paz.html

${ }^{156}$ Se refiera a una expresión latina que significa estado del momento actual.

${ }^{157}$ Henao, J. Las formas de reparación en la responsabilidad del Estado: hacia su unificación sustancial en todas las acciones contra el Estado, Revista de Derecho Privado, Universidad Externado de Colombia, n. ${ }^{\circ 28}$, enero-junio de 2015, pp. 277-366. doi: 10.18601/01234366.n28.10

${ }^{158}$ De Greiff, P. (s.f). Justicia y Reparaciones. Parte IV: Reparaciones y Reformas Institucionales, Justicia Transicional: Manual para America Latina pp.407-440. doi: http://www.corteidh.or.cr/tablas/r29767.pdf

159 Asamblea General de la ONU, Principios y directrices básicos sobre el derecho de las víctimas de violaciones manifiestas de las normas internacionales de derechos humanos y de violaciones graves del derecho internacional humanitario a interponer recursos y obtener reparaciones. Resolución 60/147 del 16 de diciembre de 2005, Principio IX. Reparación de los Daños Sufridos.
} 


\subsection{Reparación Integral}

La reparación integral es aquella que reúne todas las demás medidas de reparación como lo expone Calderón (2013), "Cada una de estas cláusulas es en sí misma una potestad para la Corte IDH para resarcir a las víctimas no solo en el goce de sus derechos sino también para modificar las consecuencias producidas por la violación" (p.11). ${ }^{160}$

La reparación integral es el agrupamiento el cual según Corte IDH (2003) citada por Arce y Moreno (2013, p.73-74), involucra el uso de medidas de restitución, indemnización, rehabilitación, satisfacción y garantías de no repetición que tiendan a hacer desaparecer los efectos de las violaciones cometidas. ${ }^{161}$

Frente a la reparación integral la Corte Interamericana de Derechos Humanos, afirma en el caso Masacres del Mozote vs El Salvador, que la reparación integral es aquella que "apunta a restablecer las relaciones de confianza en la sociedad y busca cimentar procesos que impidan la repetición del drama que la afectó con el conflicto armado no internacional"162

Así mismo, la Corte en el caso Barrios Altos vs Perú, aduce que cuando se produce daño moral y material a las víctimas, el Estado debe hacer una reparación integral. ${ }^{163}$

Estas medidas tienen un objetivo el cual según la Unidad para la Atención y Reparación Integral a las Victimas es "reconocer el daño causado, contribuir a la reconstrucción del proyecto de vida, devolver a la víctima su estatus y la garantía de sus derechos, (...)". ${ }^{164}$

Tal como se ha señalado, frente a la concurrencia de una infracción a una obligación internacional que sea atribuible al Estado, se genera responsabilidad internacional. Esto da origen a una obligación compleja para el Estado infractor. Por una parte, debe cumplir con la obligación primaria, que no cesa por el incumplimiento; y por otra, surge una obligación secundaria, la obligación de reparar. En este sentido, la Corte ha señalado que ambas obligaciones conviven, de forma tal

\footnotetext{
${ }^{160}$ Calderón, (2013). Biblioteca Jurídica Virtual del Instituto de Investigaciones Jurídicas de la UNAM. La Reparación Integral en la Jurisprudencia de la Corte Interamericana de Derechos Humanos: estándares aplicables al nuevo paradigma Mexicano [145-219]. Recuperado de http://www.corteidh.or.cr/tablas/r33008.pdf

${ }^{161}$ Arce, J. Moreno, M. Estándares internacionales en materia de reparación integral. Su devenir y ejecución en el conflicto colombiano. $\begin{array}{lllll}\text { Revista } & \text { Ciencias } & \text { Humanas, (10), Volumen }\end{array}$ https://revistas.usb.edu.co/index.php/CienciasHumanas/article/download/1736/1508

${ }_{162}$ Corte Interamericana de Derechos Humanos. Caso Masacres de El Mozote y lugares aledaños vs. El Salvador. Sentencia de 25 de octubre de 2012 (Fondo, Reparaciones y Costas) Párr.32.

163 Corte Interamericana de Derechos Humanos. Caso Barrios Altos Vs. Perú .Sentencia de 14 de marzo de 2001 (Fondo) Párr.2.

${ }^{164}$ Unidad para la Atención y Reparación Integral a las Víctimas (UARIV). (s.f). Reparación Integral Individual. Recuperado de https://www.unidadvictimas.gov.co/es/reparacion-integral-individual/286
} 
que ambas deben ser satisfechas por el Estado, tanto en sede nacional como internacional (...) (Nash Rojas, 2009, p.33). ${ }^{165}$

\subsection{Rehabilitación}

Son el conjunto de estrategias, planes y acciones de carácter jurídico, médico, psicológico y social para reestablecer las condiciones físicas y psicológicas de las víctimas. Como por ejemplo la atención psicológica para aliviar los impactos generados por el conflicto armado en la víctima. ${ }^{166}$

El señor Ángel al respecto afirmó que si bien existe un programa en el Tolima de rehabilitación, este carece de enfoque diferencial étnico, es decir es prestado para todas las víctimas de manera general y no contiene un trato especial para los afrodescendiente e indígenas. El señor Ángel manifestó, que él junto con las demás víctimas afrodescendientes quieren la presencia de funcionarios afrodescendientes que conozcan las necesidades de la comunidad. Por ejemplo, para una atención psicológica desea que sea brindada por un profesional afrodescendiente el cual conozca cuáles son las necesidades acordes a la comunidad afro en el Tolima.

El departamento del Tolima todavía desconoce lo que es "grupo étnico" por eso es que aquí el gobierno no ha hecho una rehabilitación para nosotros de los grupos étnicos, ellos lo hacen en general pero la ley dice que hay que hacer trato aparte con sus costumbres y eso hay que usar la consulta es decir si el gobierno va hacer un programa primero tiene que venir a consultar con la comunidad por ejemplo "señores les sirve o no les sirve y la comunidad de nosotros ponemos nuestras condiciones". Cuando vayan a hacer ese programa debe haber una persona de nuestra comunidad; porque esa persona conoce nuestras costumbres. En cambio aquí en el Tolima hicieron un programa de "PAPSIVI"167 pero fue para todas las víctimas en general es decir sin trato diferencial lo cual contradice el auto 266 de 2017 de la Corte Constitucional.

El servicio jurídico, médico, psicológico y social lo está prestando en general pero no específico.

\footnotetext{
${ }^{165}$ Nash Rojas, C. (2009).Universidad de Chile: Facultad de Derecho. Las Reparaciones ante la Corte Interamericana de Derechos Humanos (1988-2007), segunda edición corregida y actualizada. [1-488]. Recuperado de http://www.corteidh.or.cr/tablas/r15428.pdf

${ }^{166}$ Unidad para la Atención y Reparación Integral a las Víctimas (UARIV). (s.f). DERECHO a la Reparación Integral a las víctimas del conflicto armado; preguntas frecuentas: Imprenta Nacional de Colombia.

${ }^{167}$ Es el Programa de Atención psicosocial y salud integral a víctimas (PAPSIVI). Se define como el conjunto de actividades, procedimientos e intervenciones interdisciplinarias diseñados por el Ministerio de Salud y Protección Social para la atención integral en salud y atención psicosocial
} 
Hay mucho funcionario que desconoce el tema étnico por ignorancia ni saben que tenemos decretos ley ${ }^{168}$. Además deben identificar las víctimas, de las victimas étnicas.

Si hay víctimas étnicas deben consultar previamente con nosotros con las comunidades para saber que se va hacer.

Ángel Sinisterra, Entrevista 28 de diciembre de 2018.

\subsection{Indemnización}

La Convención Americana establece:

Cuando decida que hubo violación de un derecho o libertad protegidos en esta Convención, la Corte dispondrá que se garantice al lesionado en el goce de su derecho o libertad conculcados. Dispondrá asimismo, si ello fuera procedente, que se reparen las consecuencias de la medida o situación que ha configurado la vulneración de esos derechos y el pago de una justa indemnización a la parte lesionada. (Convención Americana, 1969, artículo 63.1)

La Corte Interamericana de Derechos Humanos frente a la indemnización menciona lo siguiente:

La indemnización por violación de los derechos humanos encuentra fundamento en instrumentos internacionales de carácter universal y regional. El Comité de Derechos Humanos, creado por el Pacto Internacional de Derechos Civiles y Políticos de las Naciones Unidas, ha acordado repetidamente, con base en el Protocolo Facultativo, el pago de indemnizaciones por violaciones de derechos humanos reconocidos en el Pacto (véanse por ejemplo las comunicaciones 4/1977; 6/1977; 11/1977; 132/1982; 138/1983; 147/1983; 161/1983; 188/1984; 194/1985; etc., Informes del Comité de Derechos Humanos, Naciones Unidas). Lo propio ha hecho la Corte Europea de Derechos Humanos con base en el artículo 50 de la Convención para la Protección de los Derechos Humanos y de las Libertades Fundamentales. (Corte Interamericana de Derechos Humanos.

\footnotetext{
${ }^{168}$ Decreto ley 4635 de 2011, Decreto por el cual se dictan medidas de asistencia, atención, reparación integral y de restitución de tierras a las víctimas pertenecientes a comunidades negras, afrocolombianas, raizales y palenqueras. Y el Convenio sobre pueblos indígenas y tribales.
} 
Caso Godínez Cruz vs Honduras. Sentencia de 21 de julio de 1989) ${ }^{169}$.

A su vez, el Derecho internacional humanitario también recoge la obligación de indemnizar en el Protocolo I adicional a los Convenios de Ginebra, en su artículo 91 y el Derecho penal internacional lo hace a través de los mecanismos previstos en los artículos 68 y 75 del Estatuto de Roma de la Corte Penal Internacional.

Mientras la indemnización para Martín (2007), “se refiere a la compensación monetaria por daños y perjuicios. Incluye tanto daño material, como físico y moral (miedo, humillación, estrés, problemas mentales, reputación)". ${ }^{170}$

Esta medida administrativa es de carácter económica. Dicha compensación la entrega el Estado teniendo en cuenta el impacto del hecho victimizante, el daño causado, estado de vulnerabilidad actual de la víctima bajo un enfoque diferencial y basándose en los principios de progresividad y gradualidad. ${ }^{171}$

Con respecto a la indemnización, la Unidad para la Atención y Reparación Integral a las Víctimas expidió la resolución número 01958 de 2018 en la cual estableció una ruta de priorización para las víctimas. En esta ruta no contempla el factor étnico y por esta razón el señor Ángel decidió tomar acciones legales junto con los demás miembros de la comunidad afrodescendiente. Don Ángel afirma que no le han hablado sobre su proyecto de vida ni de otorgarle un proyecto productivo.

La indemnización todavía no ha llegado y nosotros la estamos solicitando como grupo étnico. La indemnización la han hecho en general sea quien sea. Ahoritica sacaron una Resolución 01958 sobre la ruta de priorización ${ }^{172}$ pero nunca pusieron personas especiales étnicas, nada y por eso la demandamos y esta parada ahora.

Es que lo que pasa es que el Gobierno y la Unidad de Víctimas sacaron la ley 1448 y los decretos ley de que nos menciona a nosotros, pero ellos solo aplican la 1448.

A mí no me han hablado de mi proyecto de vida y pues está estancado. Porque el Tolima se ha quedado en eso, ellos desconocen. Porque a mí me deberían poner un proyecto productivo, devolverme mi vivienda que yo tenía. Es que el Estado tiene que devolverme las cosas que yo tenía antes para yo así hacer mi vida.

Ángel Sinisterra, Entrevista 28 de diciembre de 2018.

\footnotetext{
${ }^{169}$ Corte Interamericana de Derechos Humanos. Caso Godínez Cruz vs Honduras. Sentencia de 21 de julio de 1989. (Reparaciones y Costas). Párr.26.

170 Martín, C. (2007). Manual sobre perspectiva psicosocial en la investigación de derechos humanos. Recuperado de https://www.cejil.org/sites/default/files/legacy_files/Manual-sobre-perspectiva-psicosocial-en-la-investigacion-de-dh_0.pdf

${ }^{171}$ IDEM.

${ }^{172}$ Ruta Priorizada: Es un selecto grupo para las víctimas en razón a su enfermedad, edad, discapacidad y vulneración extrema. El cual no incluye la el contenido étnico.
} 


\subsection{Restitución}

Los principios de la ONU (2005) citados por Nash (2007) "La restitución comprende, según corresponda, el restablecimiento de la libertad, el disfrute de los derechos humanos, la identidad, la vida familiar y la ciudadanía, el regreso a su lugar de residencia, la reintegración en su empleo y la devolución de sus bienes"(p.59). ${ }^{173}$

La Restitución para Godínez (s.f) “debe buscar la plena restitución del menoscabo ocasionado, la cual consiste en el restablecimiento de la situación anterior al momento en que se presentó la violación manifiesta" (p.9). ${ }^{174}$

Las medidas de restitución son aquellas que buscan devolver a la víctima al estado anterior al hecho victimizante. Comprenden la dimensión material de la reparación integral y pueden constituirse en medidas financieras en la restitución de créditos y pasivos, coordinadas por el Programa de Acompañamiento; en la restitución vivienda a cargo del Ministerio de Vivienda y el Ministerio de Agricultura; la restitución de tierras, que coordina la Unidad de Restitución de Tierras; la restitución de capacidades para el empleo, en coordinación con el Ministerio del Trabajo y; el proceso de Retornos y Reubicaciones, a cargo de la Unidad para las Víctimas. ${ }^{175}$

Don Ángel afirmó que sus dos predios ubicados en Buenaventura están actualmente paralizados por la inseguridad que presenta Buenaventura, lo cual impide que los peritos puedan realizar las visitas y labores de campo.

En el departamento del Valle y Buenaventura dicen que iban a focalizar pero como volvió otra vez la violencia no se sabe entonces. Porque no hay un concepto de seguridad antes dieron uno pero como en noviembre volvió otra vez la violencia pues todo quedó ahí.

Don Ángel no desea radicarse en la ciudad de Ibagué porque extraña su tierra natal y porque allí es donde tiene su casa y un predio que heredó de su señor padre. Por eso al respecto de una posible reubicación manifestó lo siguiente:

Aquí en el municipio no hay una ruta de reubicación si de retorno. Y yo no me quiero quedar aquí [Ibagué].

Ángel Sinisterra, Entrevista 28 de diciembre de 2018.

\footnotetext{
173 Nash, C. (2007). Las Reparaciones ante la Corte Interamericana de Derechos Humanos. Recuperado de http://www.corteidh.or.cr/tablas/r15428.pdf

${ }^{174}$ Godínez, W. (s.f). ¿Qué y cómo restituir violaciones a derechos humanos? Lineamientos para una reparación del daño integral. [6-28] DOI: http://www.revistas.unam.mx/index.php/amicus/article/download/62500/54969

175 Unidad para la Atención y Reparación Integral a las Víctimas (UARIV). (s.f). Ruta Integral Individual. Recuperado de http://www.unidadvictimas.gov.co/es/atencion-asistencia-y-reparacion-integral/ruta-integral-individual/11416
} 


\subsection{Medidas de Satisfacción}

De acuerdo a la Comisión Interamericana de Derechos Humanos, las medidas de satisfacción presentan la siguiente noción:

"La satisfacción es definida por la doctrina como toda medida que el autor de una violación debe adoptar, conforme al derecho consuetudinario o a un tratado, aparte de la restitución y la compensación y que tiene como fin el reconocimiento de la comisión de un acto ilícito. Se ha señalado asimismo que es deber de los órganos de supervisión internacional el garantizar, en aras de la satisfacción, que los remedios disponibles protejan no solamente la parte individual sino que sirvan también para prevenir nuevas violaciones y apoyar el orden legal establecido en los tratados ${ }^{176}$."(Comisión Interamericana de Derechos Humanos (s.f), Caso 19 comerciantes vs Colombia).

Según los principios de la ONU sobre reparaciones, las medidas de satisfacción comprenden las siguientes 8 medidas:

“A) las Medidas eficaces para conseguir la cesación de las violaciones continuadas. B) La verificación de los hechos y la revelación pública y completa de la verdad, en la medida en que esa revelación no provoque más daños o amenace la seguridad y los intereses de la víctima, de sus familiares, de los testigos o de personas que han intervenido para ayudar a la víctima o impedir que se produzcan nuevas violaciones. C) La búsqueda de las personas desaparecidas, de las identidades de los niños secuestrados y de los cadáveres de las personas asesinadas, y la ayuda para recuperarlos, identificarlos y volver a inhumarlos según el deseo explícito o presunto de la víctima o las prácticas culturales de su familia y comunidad. D) Una declaración oficial o decisión judicial que restablezca la dignidad, la reputación y los derechos de la víctima y de las personas estrechamente vinculadas a ella. $E$ ) Una disculpa pública que incluya el reconocimiento de los hechos y la aceptación de responsabilidades $F$ ) La aplicación de sanciones judiciales o administrativas a los responsables de las violaciones. $G$ ) Conmemoraciones y homenajes a las víctimas. $H$ ) La inclusión de una exposición precisa de las violaciones ocurridas en la enseñanza de las normas internacionales de derechos humanos y del derecho internacional humanitario, así como en el material didáctico a todos los niveles". (Principios y directrices básicos sobre el derecho de las víctimas de violaciones manifiestas de las normas internacionales de derechos humanos y de violaciones graves del derecho internacional humanitario, (2005), Resolución 60/147). ${ }^{177}$

\footnotetext{
${ }^{176}$ Comisión Interamericana de Derechos Humanos. (s.f).Escrito sobre las Reparaciones debidas por la República de Colombia. Caso 19 Comerciantes vs Colombia. Recuperado de http://www.corteidh.or.cr/docs/casos/comerciantes/arg_rep_com.pdf

177 Asamblea General de la ONU, Principios y directrices básicos sobre el derecho de las víctimas de violaciones manifiestas de las normas internacionales de derechos humanos y de violaciones graves del derecho internacional humanitario a interponer recursos y obtener reparaciones. Resolución 60/147 del 16 de diciembre de 2005.
} 
Las medidas de satisfacción hacen parte de las dimensiones individual y colectiva de las Reparación, que buscan resarcir el dolor a través de la reconstrucción de la verdad, la difusión de la memoria histórica y la dignificación de las víctimas. ${ }^{178}$

Frente a las medidas de satisfacción, Don Ángel declaró que no está de acuerdo con hacer procesos de memoria histórica. Para él, las medidas de satisfacción es devolverles a las víctimas sus condiciones como eran antes de que ocurrieran los hechos.

La memoria histórica no estoy de acuerdo eso es gastar un poco de plata y ya, o ponen un monumento en una plaza y ya. Eso no son medidas de satisfacción para una víctima. La medida de satisfacción para una víctima es que vuelva a como estaba antes del conflicto.

Para su caso particular las medidas de satisfacción serían:

Que me devuelvan la tierra de mi papa, mi casa, que yo vuelva a mi tierra y que vuelva hacer mi labor que yo hacía, o trabajo pero allá. Porque si ya me quedo por acá me tienen que poner un proyecto de vida, un proyecto productivo que yo pueda generar mi ingreso el cual pues está estancado.

Ángel Sinisterra, Entrevista 28 de diciembre de 2018.

\subsection{Garantías de No Repetición}

Son consideradas tanto una de las formas de reparación a las víctimas como uno de los principios generales de responsabilidad internacional de los Estados. Dichas garantías a diferencia de las medidas de restitución, indemnización, rehabilitación y satisfacción se encuentran dirigidas a la sociedad con el propósito que no se repitan la vulneración de los derechos de las víctimas, así como eliminar y superarlas causas estructurales de la violación masiva a los derechos humanos y/o al derecho internacional humanitario al interior de la sociedad. Las garantías de no repetición comprenden dos dimensiones: una preventiva y otra reparadora.

La dimensión preventiva surge de la obligación internacional que tienen los Estados de prevenir las violaciones a los derechos humanos e infracciones al derecho internacional humanitario, y cobra especial importancia en procesos transicionales donde el riesgo persiste, y no basta con reparar los daños ya infligidos sino prevenir los futuros. Por ejemplo, el desminado y la prevención de reclutamiento.

La dimensión reparadora se refiere a acciones que correspondan a mitigar los daños infringidos a las víctimas en violación a sus derechos humanos e infracciones al derecho internacional humanitario, teniendo eco en acciones de carácter institucional, político, económico y social que beneficien a la sociedad en general. Por ejemplo, la socialización de la verdad judicial, pedagogía social en derechos humanos, eliminación de patrones culturales, entre otras.

\footnotetext{
178 IDEM.
} 
La implementación efectiva de las garantías de no repetición aseguran el logro de la paz y el fortalecimiento de la democracia, teniendo en cuenta que las garantías de no repetición deben responder a los contextos, características y necesidades territoriales. Así mismo, la Unidad para las Víctimas ha basado su desarrollo y aplicación sobre el desarrollo de un enfoque de reconciliación que tienda a restablecer la confianza, la democracia, los derechos de las víctimas, y el territorio entre el Estado, las comunidades y los antagonistas. ${ }^{179}$

Para Don Ángel, las garantías de no repetición en su natal Buenaventura serían las que ayuden a contrarrestar el desempleo principalmente. Incentivando el arribo de empresarios a Buenaventura para que generen empleo y que se empiece a creer en la mano de obra local, dado que en muchos casos según Don Ángel las empresas contratan personal de afuera de Buenaventura impidiendo el empleo a los lugareños.

Además, manifestó que para el Gobierno Nacional la solución a los problemas es incrementar el pie de fuerza en la ciudad puerto. Ante esta afirmación coincide con su amigo y paisano el señor $*$ Juan.

Mire la solución han creído que es meter más fuerza pública, meter tanquetas a patrullar porque en Buenaventura patrullan con tanquetas blindadas y eso no ha servido (...).

Juan, Entrevista 14 de noviembre de 2018.

El gobierno debe llevar obras sociales a Buenaventura y no llevar ejército. Porque piensa el Estado que con llevar ejercito ya con eso se van a solucionar los problemas. Debe es llevar fuente de trabajo, empresas. Porque los problemas en Buenaventura son sociales, que la gente pueda generar su ingreso diario. Pero sino pues viene un grupo armado y los absorben porque les dice ustedes se van a ganar esto y ya listo entonces aceptan.

Llevar empresas que generen empleo allá y que dentro del puerto las empresas que están funcionando le den trabajo a la gente de ahí y no llevar los de otras partes. Porque que sacan con capacitar a la gente si no les dan trabajo, porque hay mucha gente capacitada pero con el título en la casa porque no hay las vacantes porque son para la gente de afuera.

Ángel Sinisterra, Entrevista 28 de diciembre de 2018.

De acuerdo con lo mencionado sobre las medidas de reparación, el señor Ángel afirma que estas medidas se están prestando por parte de las autoridades a las víctimas pero algunas se cumplen parcialmente y otras medidas en cambio aún no se han hecho efectivas.

Como tal, Don Ángel aduce que si bien en el departamento del Tolima hay un programa para la atención a las víctimas del conflicto armado, este programa no cuenta con un enfoque étnico. Lo cual no satisface las necesidades propias de su comunidad afrodescendiente. Como lo resaltó anteriormente el Doctor en psicología Martín Beristaín hay que tener en cuenta la cultura a la que pertenecen las víctimas para así mismo brindarle un trato especial conforme a las costumbres de la comunidad de la cual pertenecen las víctimas.

\footnotetext{
${ }^{179}$ IDEM.
} 
Además, a Don Ángel se estaría desconociendo el Decreto ley 4635 de 2011, Decreto por el cual se dictan medidas de asistencia, atención, reparación integral y de restitución de tierras a las víctimas pertenecientes a comunidades negras, afrocolombianas, raizales y palenqueras. También, se estaría desconociendo el Convenio 169 sobre pueblos indígenas y tribales, junto con el auto 266 de 2017 de la Corte Constitucional.

Conforme a las medidas de rehabilitación e indemnización, éstas al no contar con un enfoque étnico no le han brindado al señor Ángel una atención especial y prioritaria.

En la medida de restitución a Don Ángel si bien ya la Unidad de Restitución de Tierras le reconoció una casa y un lote ubicados el primero la ciudad de Buenaventura y el segundo en zona rural de dicho municipio, estos inmuebles continúan en proceso de focalización por motivos de inseguridad en la zona.

Con respecto a la satisfacción, Don Ángel no ha recibido por parte del Estado una medida que ayude a resarcir el daño que se le ocasionó como por ejemplo su proyecto de vida continúa interrumpido, al igual que las investigaciones contra los presuntos responsables de cometer las amenazas.

Frente las garantía de no repetición, como se mencionó anteriormente Don Ángel y su amigo el señor *Juan afirman que para que no se cometan otra vez los hechos de tortura, desplazamientos forzados y amenazas en Buenaventura, el Estado debe aceptar que militarizar el puerto no es la solución, ya que los problemas allí son sociales se generan por la falta de empleo. Se afirma también, que en la ciudad portuaria se requiere con urgencia incentivar a los empresarios quienes a su vez puedan generar empleos y se comprometan a otorgar esos empleos a los lugareños.

Las medidas de reparación en el caso de Don Ángel Sinisterra carecen del enfoque étnico pese a la existencia del Convenio 169 sobre pueblos indígenas y tribales, el Decreto ley 4635 de 2011, y el auto 266 de 2017 de la Corte Constitucional los cuales amparan su atención especial y prioritaria por pertenecer a la comunidad afrodescendiente de Colombia. Lo anterior, imposibilita que Don Ángel adquiera una medida de reparación integral es decir que sea completa, acorde a sus necesidades, que resarzan sus derechos y que desaparezcan los efectos de las violaciones. 


\section{CONCLUSIONES}

A la luz de los hechos narrados por el señor Luis Ángel Sinisterra se pudieron analizar elementos que hacen parte de violaciones de derechos humanos e infracciones al derecho internacional humanitario que nos llevó a investigar el caso por la gravedad de las vulneraciones junto al contexto que rodearon las mismas.

Los hechos de tortura, desplazamiento forzado y las amenazas ocurrieron en un contexto histórico de violencia, principalmente en Buenaventura, una ciudad que fue cruelmente azotada por el conflicto armado colombiano. En el año 2005 iniciaron los hechos de tortura, dos desplazamientos forzados y las amenazas contra Don Ángel.

Estos hechos se padecieron en el periodo más crítico de violencia en la ciudad puerto cuando arribó el grupo paramilitar Bloque Calima a cargo de alias H.H instauró el periodo conocido como "las mil muertes." Este periodo fue particularmente caracterizado por las masacres, amenazas, desplazamientos y hostigamientos a la población civil, principalmente a los líderes sociales y defensores de derechos humanos que se opusieron al accionar violento de los paramilitares en la zona.

Los hechos victimizantes sucedieron con la aquiescencia y permisividad del Estado. Según declaraciones de exjefes paramilitares, quienes afirmaron la existencia de una cooperación con agentes estatales junto con narcotraficantes e incluso con empresarios de la zona para contrarrestar el accionar de las FARC y el ELN, debido a que estos grupos ilegales hacían fuerte presencia en la zona, controlando así las rutas del narcotráfico. Por si fueran pocos los problemas en Buenaventura, el abandono estatal es histórico y evidente lo cual facilitó el accionar de los grupos armados ilegales en esta zona del país.

A raíz del abandono y la permisividad, se generó una responsabilidad internacional del Estado por hechos de terceros. Esta responsabilidad atribuible al Estado es a causa de los deberes fundamentales de respeto y garantía establecidos en la Convención Interamericana de Derechos Humanos, en su artículo 1.1. Junto con el principio Erga Omnes de estas obligaciones de garantía y respeto de derechos humanos que ocasiona una responsabilidad en un sentido más amplio, cubriendo no sólo relaciones entre Estado y sus agentes estatales sino también hacia a los particulares mediante una responsabilidad internacional indirecta. En el caso sub júdice fueron los grupos paramilitares los responsables de la mayoría de los hechos victimizantes padecidos por Don Ángel.

Entre los hechos padecidos por Don Ángel mencionados anteriormente, se encuentra la tortura, la cual en diferentes instrumentos internacionales está contemplada como un crimen que atenta contra los derechos humanos, siendo una obligación de los Estados de prevenirla y sancionarla. De igual forma, con la tortura se vulneró el sistema universal de derechos humanos. Donde se encuentran los siguientes instrumentos internacionales que la prohíben como el Pacto Internacional de Derechos Civiles y Políticos de 1966, la Declaración sobre la protección de todas las personas contra la tortura y otros tratos o penas crueles, 
inhumanos o degradantes de la Asamblea General No 3452 del 9 de diciembre de 1975 y la Convención contra la tortura y otros tratos o penas crueles, inhumanas o degradantes de 1984.

Bajo este aspecto, el Sistema Interamericano de derechos humanos, se vulneró la Convención Americana sobre Derechos Humanos de 1969 y la Convención Interamericana para Prevenir y Sancionar la Tortura de 1985. En los anteriores instrumentos se prohíben todos los actos de tortura y tratos crueles que atentan contra la dignidad humana y que puede presentarse tanto física como psicológicamente. Así como también, afirman que la tortura puede ser cometida tanto por funcionarios públicos como por particulares y siempre existirá un motivo para infligirla.

Para el Derecho Internacional Humanitario, en la tortura no se requiere la participación de una persona en ejercicio de sus funciones públicas para que los tratos destinados a infligir dolores o sufrimientos sean considerados como tortura, basta con la existencia de un propósito concreto como por ejemplo obtener información o imponer un castigo.

Como también Don Ángel fue víctima de desplazamiento forzado se le vulneró así a nivel del sistema universal de derechos humanos, los Principios Rectores de Los Desplazamientos Internos de la ONU. En los principios 1,3, 4.1 y 11.2. Los Estados tienen la obligación de elaborar estrategias cuyo objetivo sea mitigar los impactos del desplazamiento, brindando alimentos, medicinas y viviendas a través de sus instituciones bajo marcos normativos para dicha ayuda humanitaria. Estas estrategias deben garantizar enfoques étnicos, de género y de cualquier otra índole que garanticen el acceso a las ayudas y eviten revictimizar a la población desplazada.

A Don Ángel se le vulneró también el Sistema Interamericano de derechos humanos ya que la Convención Americana De Derechos Humanos, en sus artículos 22.1, 22.3 y 22.5 afirman que "a nadie se le puede privar su derecho a circular o de residencia tampoco ha ser expulsado o privado de ingresar al territorio." Como sucedió en Buenaventura, cuando los paramilitares expulsaron a Don Ángel de su casa y le prohibieron volver a través de amenazas de muerte.

En este mismo aspecto, el Derecho Internacional Humanitario exige el respeto de los protocolos adicionales a los convenios de Ginebra de 1977 en los que se reafirma la protección a las víctimas de desplazamientos forzados en los conflictos armados ya sean de índole internacional o interno.

El tercer hecho victimizante que padece el señor Ángel fueron las amenazas, las cuales en el sistema universal de derechos humanos mediante los Principios Rectores de los Desplazamientos Internos del Representante Especial del Secretario General de la ONU Informe E/CN.4/1998/Add.2, en su artículo 11.1 "Todo ser humano tiene derecho a la dignidad y a la integridad física, mental o moral". Y el artículo 11.C) son "actos de violencia destinados a sembrar terror". Así mismo prohíbe las amenazas. 
Las amenazas en el Sistema Interamericano de derechos humanos vulneran la Convención Americana sobre Derechos Humanos de 1969, en su artículo 4.1: Derecho a la Vida. Toda persona tiene derecho a que se respete su vida. Nadie puede ser privado de la vida arbitrariamente.

En el Derecho Internacional Humanitario, las amenazas se encuentran prohibidas en el cuarto Convenio de Ginebra en su artículo 33 y en el Protocolo Adicional II en su artículo 4. Se prohíben las amenazas o también conocidas como medidas de intimidación o de terrorismo contra la población civil o quienes hayan dejado las hostilidades.

Al realizar el análisis consistente en definir cada hecho victimizante a la luz de los instrumentos internacionales y nacionales de protección de derechos humanos se logró concluir que reúnen los elementos que constituyen un crimen internacional. Dichos elementos son que el hecho victimizante sea catalogado por el Estatuto de Roma como un crimen de lesa humanidad, crimen de guerra, sea parte de un ataque generalizado o sistemático y esté bajo un plan o política.

La tortura que padeció Don Ángel es un crimen internacional ya que reúne los elementos que constituyen el crimen de guerra como también el de lesa humanidad. El primero, por haber sucedido la tortura bajo un plan o política de los paramilitares del Bloque Calima en cumplimiento del plan conocido como "las mil muertes" y auspiciado en complicidad de las fuerzas estatales. Es un crimen de lesa humanidad ya que fue en el marco de un ataque sistemático llevado a cabo por un tercero como los paramilitares, se caracterizó por una fuerte represión contra la población civil de Buenaventura. El ataque fue dirigido especialmente aquellos que se opusieron al accionar paramilitar del Bloque Calima.

Frente al desplazamiento, este reúne las características de un crimen internacional debido a que Don Ángel fue desplazado forzadamente como parte de un ataque sistemático contra la población civil, ya que los diferentes actores armados tienen en común que su blanco es la población civil cuya dinámica es mediante el conflicto y la violencia desplazar a los civiles para apoderarse de sus tierras y convertirlas en zonas de cultivos ilícitos. Además, el desplazamiento forzado padecido por Don Ángel se dio bajo el pretexto de los paramilitares de combatir insurgencia guerrillera, señalaban a cualquier persona de ser colaborador de las FARC.

Respecto a las amenazas, Don Ángel fue amenazado por parte de los grupos armados al margen de la ley primeramente en Buenaventura donde existió un ataque sistemático en contra de los defensores de derechos humanos y líderes sociales que se opusieron al accionar paramilitar en la zona. En Ibagué Don Ángel también recibió amenazas de diferentes grupos armados ilícitos por su labor social.

Los hechos victimizantes de tortura. Desplazamiento forzado y las amenazas crearon unos daños materiales e inmateriales que impactaron a Don Ángel. Frente a los impactos el señor Ángel al ser miembro de la comunidad afrocolombiana reviste una característica especial y presenta una ruptura con su comunidad, naturaleza y territorio. Sus daños fueron de carácter material y psíquico. El daño material, se ocasionó al ser despojado de su casa y un 
lote en la ciudad de Buenaventura por parte de los paramilitares. Mientras que con el daño psíquico afecto al señor Ángel ya que padece de paranoia, siente desconfianza y miedo lo cual le impide llevar su vida cotidiana. También el señor Ángel sufrió a causa de las actuaciones u omisiones de las autoridades un daño psíquico por falta de respuesta estatal.

El daño afectó también el proyecto de vida del señor Ángel, quien actualmente se encuentra estancado y este no cuenta con un enfoque étnico que requiere para apoyar su crecimiento personal y resarcir el daño causado.

Las vulneraciones que le produjeron los daños a Don Ángel requieren ser resarcidos respecto a este tema, sin embargo, las medidas de reparación han sido escasas debido a que no son integrales, ya que son incompletas y su acceso es limitado.

En el caso de Don Ángel, la rehabilitación, la indemnización y las medidas de satisfacción no se le han brindado como corresponde al no contar con su respectivo enfoque étnico, pese a que tienen un respaldo legal que garantiza su atención prioritaria y especial al ser Don Ángel parte de la comunidad afrocolombiana. En cambio, con la restitución Don Ángel ha avanzado un poco más ya que la Unidad de Restitución de Tierras le reconoció sus bienes inmuebles. El proceso se encuentra en la primera etapa de la restitución, es decir en la etapa adminsitrativa. Con respecto a la casa ubicada en el casco urbano de Buenaventura actualmente se le esta realizando el respectivo estudio formal. Mientras que con el predio ubicado en zona rural de Buenaventura, se encuentra en el análisis previo pero actualmente esta suspendido por las condiciones de inseguridad que impiden que avanzace el proceso. Frente a las garantías de no repetición, según Don Ángel y su amigo Juan se requiere de políticas estatales que generen empleos y estudio para los bonaverenses, pero lo que se ha hecho es militarizar Buenaventura.

De acuerdo al análisis planteado anteriormente, conllevo a determinar que el caso de Don Ángel, es de gran importancia para ser investigado, debido a las circunstancias que lo envuelven. Como lo es el contexto donde se produjeron los hechos, una zona históricamente azotada por la violencia con débil presencia del Estado, la aquiescencia entre agentes estatales y grupos armados ilegales, hostigamientos a la pobladores entre ellos afrocolombianos y defensores de derechos humanos. Las vulneraciones bajo estándares internacionales son consideradas violaciones a los derechos humanos e infracciones al derecho internacional humanitario y constituyen crímenes internacionales. 


\section{LISTA DE REFERENCIAS}

Alfonso Carla y Martín Beristain. (2013). Ruta Pacífica de las Mujeres. Bilbao, España: Universidad del País Vasco y Hegoa.

Amnistía Internacional. (s.f.). En Que Estamos, Tortura. Recuperado de https://www.es.amnesty.org/em-que-estamos/temas/tortura/

Amnistía Internacional. (s.f.). En Que Estamos, Tortura. Recuperado de https://www.es.amnesty.org/em-que-estamos/temas/tortura/

Arce, J. Moreno, M. Estándares internacionales en materia de reparación integral. Su devenir y ejecución en el conflicto colombiano. Revista Ciencias Humanas, Volumen (10), [69-81]. doi: https://revistas.usb.edu.co/index.php/CienciasHumanas/article/download/1736/ 1508

Asamblea General de la ONU. Consejo de Derechos Humanos. (2012). Informe del Relator Especial sobre la promoción de la Verdad, la Justicia, la Reparación y las Garantías de No Repetición, Pablo De Greiff. Recuperado de: https://www.ohchr.org/Documents/HRBodies/HRCouncil/RegularSession/Sessi on21/A-HRC-21-46_sp.pdf

Atebortúa Arredondo C. (2009). Diálogos de Saberes. Límites para el Concepto del Desplazamiento Forzado Intraurbano. El Papel de la Acción de Tutela y de la Jurisprudencia en su Construcción. Revista (30), 241-260. doi: file:///C:/Users/felipe/Downloads/Dialnet-

LimitesParaElConceptoDeDesplazamientoForzadoIntrau-3224480.pdf

Banco Mundial. (2015). Preguntas frecuentes: El Desplazamiento Forzado, Una Crisis Mundial Cada Vez Mayor. Recuperado de http://www.bancomundial.org/es/topic/fragilityconflictviolence/brief/forceddisplacement-a-growing-global-crisis-faqs

Fedesarrollo-CERAC. (2013). Hacia un Desarrollo Integral de la Ciudad de Buenaventura y su Área de Influencia. Recuperado de https://www.repository.fedesarrollo.org.co/bitstream/handle/11445/198/Hacia\% $20 \mathrm{un} \% 20$ desarrollo $\% 20$ integral $\% 20 \mathrm{de} \% 20 \mathrm{la} \% 20$ ciudad $\% 20 \mathrm{de} \% 20 \mathrm{Buenaventu}$ ra\%20y\%20su\%20area\%20de\%20influencia\%20-

$\% 20$ Informe $\% 20$ final $\% 202013$.pdf?sequence $=2$

Botero, J., Páez E. (junio de 2013). La Resiliencia y el Afrontamiento Positivo: Conceptos Atados. Caminos para la Resiliencia. Recuperado de http://www.udea.edu.co/wps/wcm/connect/udea/2f56b608-5bdc-44c5-a78a83298c5f54ea/BoletA\%CC\%83\%C2\%ADn+3_Afrontamiento+y+Resiliencia.p df?MOD=AJPERES\&CVID=lglruPA 
Calderón, (2013). Biblioteca Jurídica Virtual del Instituto de Investigaciones Jurídicas de la UNAM. La Reparación Integral en la Jurisprudencia de la Corte Interamericana de Derechos Humanos: estándares aplicables al nuevo paradigma Mexicano [145-219]. Recuperado de http://www.corteidh.or.cr/tablas/r33008.pdf

Calderón, J. (2013). La Reparación Integral en la Jurisprudencia de la Corte Interamericana de Derechos Humanos: Estándares Aplicables al Nuevo paradigma Mexicano. Recuperado de: http://www.corteidh.or.cr/tablas/r33008.pdf

Caracol Radio. (04/09/08). Alias "HH" confiesa que las AUC asesinaron a más de mil personas en Buenaventura. Judicial. Recuperado de http://caracol.com.co/radio/2008/09/04/judicial/12205250040_664894.html Carrasco Andrino. (2010). Derecho Penal: Parte Especial. Amenazas y Coacciones, [1-7]. Recuperado de https://rua.ua.es/dspace/bitstream/10045/24640/2/COACCIONES_Y_AMENA ZAS.pdf

Instituto Nacional de Medicina Legal y Ciencias Forenses. (2005). Forensis Datos para la Vida. Homicidio, [p.71]. Recuperado de http://www.medicinalegal.gov.co/documents/20143/49493/Homicidio.pdf

CEJIL (2005) Debates sobre los Derechos Humanos y el Sistema Interamericano. Recuperado de https://cejil.org/es/revista-cejil-ano-i-no-1debates-derechos-humanos-y-sistema-interamericano

Centro Nacional de Memoria Histórica (2018), Bloque Calima de las AUC. Depredación paramilitar y narcotráfico en el suroccidente colombiano. Informe No. 2, Bogotá, CNMH.

Centro Nacional de Memoria Histórica-CNMH, (08 de marzo de 2018). La Resistencia de Buenaventura. Noticias CNMH. Recuperado de http://www.centrodememoriahistorica.gov.co/noticias/noticias-cmh/laresistencia-de-buenaventura

Centro Nacional de Memoria Histórica-CNMH, Buenaventura: Un Puerto sin Comunidad y también en los informes de Rutas del Conflicto sobre las masacres en Buenaventura.

Centro Nacional de Memoria Histórica-CNMH. (2015), Buenaventura: Un Puerto sin Comunidad. (p. 235).

Centro Nacional de Memoria Histórica-CNMH. (2015), Buenaventura: Un Puerto sin Comunidad. (p. 237).

Centro Nacional de Memoria Histórica-CNMH. (2015), Buenaventura: Un Puerto sin Comunidad. (p. 238). 
Centro Nacional de Memoria Histórica-CNMH. (2015), Buenaventura: Un Puerto sin Comunidad. (p. 260).

Centro Nacional de Memoria Histórica-CNMH. (2015), Buenaventura: Un Puerto sin Comunidad. (p. 275).

Centro Nacional de Memoria Histórica-CNMH. (2015). Buenaventura: Un Puerto sin Comunidad. (p 232).

Centro Nacional de Memoria Histórica-CNMH. (2015). Buenaventura: Un Puerto sin Comunidad. (p.165).

Centro Nacional de Memoria Histórica-CNMH. (2015). Buenaventura: Un Puerto sin Comunidad, (p.168).

Centro Nacional de Memoria Histórica-CNMH. (2015). Buenaventura: Un Puerto sin Comunidad, (p.234).

Clínica Universidad de Navarra (CUN). (2019). Diccionario Medico. Recuperado de https://www.cun.es/diccionario-medico/terminos/afrontamiento Comisión Interamericana de Derechos Humanos. (s.f).Escrito sobre las Reparaciones debidas por la República de Colombia. Caso 19 Comerciantes vs Colombia. Recuperado de http://www.corteidh.or.cr/docs/casos/comercian

Comisión Nacional de Derechos Humanos, (2017). Desplazamiento Interno por Violencia en México. Causas, consecuencias y responsabilidades del Estado. Edición (1). [1-110]. doi: https://archivos.juridicas.unam.mx/www/bjv/libros/11/5197/9.pdf

Comité Internacional de la Cruz Roja (CICR). (2005).¿Qué se entiende por tortura y malos tratos? Recuperado de https://www.icrc.org./es/doc/resources/documents/misc/69tjvk.htm

Comité Internacional de la Cruz Roja y de la Media Luna Roja (Diciembre de 2003). Derecho Internacional Humanitario y Terrorismo: Respuestas a Preguntas Clave. Recuperado de https://www.icrc.org/es/faq/derechointernacional-humanitario-y-terrorismo-respuestas-preguntas-clave

Comité Internacional de la Cruz Roja. (1998). Principios Rectores relativos al desplazamiento de personas en el interior de su propio país. Recuperado de https://www.icrc.org/es/doc/resources/documents/misc/5tdmg6.htm

Cuya, E. (s.f). Las Comisiones de la Verdad en América Latina. Recuperado de http://www.derechos.org/koaga/iii/1/cuya.html

De Greiff, P. (s.f). Justicia y Reparaciones. Parte IV: Reparaciones y Reformas Institucionales, Justicia Transicional: Manual para America Latina pp.407-440. doi: http://www.corteidh.or.cr/tablas/r29767.pdf 
Defensoría del Pueblo (septiembre de 2003) Resolución Defensorial Regional. Sobre la situación de derechos humanos de la población desplazada en el municipio de Buenaventura Bogotá D.C. (017), [p.3]. doi: http://www.defensoria.gov.co/attachment/256/regional17.pdf

Defensoría del Pueblo. (s.f). El Desplazamiento Forzado por la Violencia en Colombia. Informe Defensorial sobre el Desplazamiento Forzado por la $\begin{array}{llll}\text { Violencia en } & \text { Colombia 2]. }\end{array}$ http://www.defensoria.gov.co/attachment/48/El\%20Desplazamiento\%20Forzad o\%20por\%20la\%20Violencia\%20en\%20Colombia\%20-.pdf

Defensoría del Pueblo. (s.f.). El Desplazamiento Forzado por La Violencia en Colombia. Recuperado de http://www.defensoria.gov.co/es/public/Informesdefensoriales/765/ElDesplazamiento-Forzado-por-la-Violencia-en-Colombia-desplazamientoforzado-en-Colombia-Informes-defensoriales---Conflicto-Armado-Informesdefensoriales---Derecho-Internacional-Humanitario

Defensoría Del Pueblo. (Septiembre de 2003).Resolución Defensorial Regional. (017). Sobre la situación de derechos humanos de la población desplazada en el municipio de Buenaventura. [p.3-4]. doi: http://www.defensoria.gov.co/attachment/256/regional17.pdf

Defensoría Del Pueblo. (Septiembre de 2003).Resolución Defensorial Regional. (017). Sobre la situación de derechos humanos de la población desplazada en el municipio de Buenaventura. [p.15]. doi: http://www.defensoria.gov.co/attachment/256/regional17.pdf

Defensoría del Pueblo. Resolución Defensorial No. 025 Sobre las Violaciones Masivas de Derechos Humanos y Desplazamiento Forzado en la Región del Bajo Atrato Chocoano, octubre de 2002 (expediente de prueba, folio 230).

Defensoría Del Pueblo. Resolución Defensorial Regional. (017). Sobre la situación de derechos humanos de la población desplazada en el municipio de Buenaventura. [P.15]. doi: http://www.defensoria.gov.co/attachment/256/regional17.pdf

Dirección de la Fiscalía Nacional de Derechos Humanos y Derecho Internacional Humanitario. Homicidio del humorista Jaime Garzón es de lesa humanidad: Fiscalía. Boletín No.15975 del 30 de septiembre de 2016. Recuperado de https://www.fiscalia.gov.co/colombia/noticias/homicidio-delhumorista-jaime-garzon-es-de-lesa-humanidad-fiscalia/ 
Dirección Nacional de Análisis y Contextos (DINAC) de la Fiscalía. Declara casos de integrantes de la UP como crímenes de lesa humanidad. Boletín No.8037 del 20 de octubre de 2014. Recuperado de https://www.fiscalia.gov.co/colombia/noticias/destacada/fiscalia-declara-casosde-integrantes-de-la-up-como-crimenes-de-lesa-humanidad/

Fiscalía General de la Nación. (2016). Cargos contra estudiante de derecho por amenazar a profesora que lo reprobó. Recuperado de https://www.fiscalia.gov.co/colombia/seccionales/cargos-contra-estudiante-dederecho-por-amenazar-a-profesora-que-lo-reprobo/

Godínez, W. (s.f). ¿Qué y cómo restituir violaciones a derechos humanos? Lineamientos para una reparación del daño integral. [6-28] DOI: http://www.revistas.unam.mx/index.php/amicus/article/download/62500/54969

Gutiérrez E. (05 de junio de 2015). Buenaventura 14 años de violencia. El Espectador. Recuperado de: https://www.elespectador.com/noticias/nacional/buenaventura-14-anos-deviolencia-articulo-564875

Gutiérrez E. (05 de junio de 2015). Buenaventura 14 años de violencia. El Espectador. Recuperado de: https://www.elespectador.com/noticias/nacional/buenaventura-14-anos-deviolencia-articulo-564875

Henao, J. Las formas de reparación en la responsabilidad del Estado: hacia su unificación sustancial en todas las acciones contra el Estado, Revista de Derecho Privado, Universidad Externado de Colombia, n. ${ }^{\circ} 28$, enero-junio de 2015, pp. 277-366. doi: 10.18601/01234366.n28.10

Human Rights Watch (HRW). (2014). La Crisis en Buenaventura: Desapariciones, Desmembramientos y desplazamiento en el principal puerto de Colombia en el pacífico. Recuperado de https://www.hrw.org/es/report/2014/03/20/la-crisis-enbuenaventura/desapariciones-desmembramientos-y-desplazamiento-en-el

Human Rights Watch. (20 de maro de 2014). La Crisis en Buenaventura: Desapariciones, Desmembramientos y Desplazamiento en el Principal Puerto de Colombia en el pacífico. Recuperado de https://www.hrw.org/es/report/2014/03/20/la-crisis-enbuenaventura/desapariciones-desmembramientos-y-desplazamiento-en-el 
Human Rights Watch. (20 de marzo de 2014). La Crisis en Buenaventura; Desapariciones, desmembramientos y desplazamiento en el principal puerto de

Colombia en el pacífico. Recuperado de https://www.hrw.org/es/report/2014/03/20/la-crisis-enbuenaventura/desapariciones-desmembramientos-y-desplazamiento-en-el

Instituto Interamericano de Derechos Humanos (IIDH). (2008). Diálogos Sobre la Reparación; Experiencias en el Sistema Interamericano de Derechos Humanos. Recuperado de https://www.iidh.ed.cr/IIDH/media/2120/dialogo_reparacion_tomo1.pdf

Instituto Interamericano de Derechos Humanos (IIDH). (2008). Diálogos Sobre la Reparación; Experiencias en el Sistema Interamericano de Derechos Humanos. Recuperado de https://www.iidh.ed.cr/IIDH/media/2120/dialogo_reparacion_tomo1.pdf

Instituto Interamericano de Derechos Humanos (IIDH). (2008). Diálogos Sobre la Reparación; Experiencias en el Sistema Interamericano de Derechos Humanos. Recuperado de https://www.iidh.ed.cr/IIDH/media/2120/dialogo_reparacion_tomo1.pdf

Irriberri A. (s.f). Que es un Proyecto de Vida. [p.1]. doi: https://moodle2.unid.edu.mx/dts_cursos_mdl/lic/AE/VC/AM/AF/proyecto_de_ vida_nuevo.pdf

J. C. Henao, "Las formas de reparación en la responsabilidad del Estado: hacia su unificación sustancial en todas las acciones contra el Estado", Revista de Derecho Privado, Universidad Externado de Colombia, n. ${ }^{\circ} 28$, enero-junio de 2015, pp. 277-366. DOI: 10.18601/01234366.n28.10

Maciá, R. (s.f). La Dualidad del Daño Patrimonial y del Daño Material. Revista de Responsabilidad Civil y de Seguro. [21-32]. doi: http://asociacionabogadosrcs.org/doctrina/rc36doctrina2.pdf

Martín, C. (2007). Manual sobre perspectiva psicosocial en la investigación de derechos humanos. Recuperado de https://www.cejil.org/sites/default/files/legacy_files/Manual-sobre-perspectivapsicosocial-en-la-investigacion-de-dh_0.pdf

Medina Ardila, F. (s.f) La Responsabilidad Internacional del Estado por actos de particulares: análisis jurisprudencial interamericano. Obligación de Respetar: Los estados deben proteger los derechos y libertades de la convención americana y el poder público tiene unos límites que surgen de los derechos humanos inherentes a las personas. 
Aníbal, D., Ruiz, G. (2011). El Delito de la Tortura en la Legislación Colombiana y su contraste con la normatividad internacional. [p.203]. doi: https://revistas.unisimon.edu.co/index.php/justicia/article/download/907/895

Medina Ardila, F. (s.f) La Responsabilidad Internacional del Estado por actos de particulares: análisis jurisprudencial interamericano. Obligación de Garantía: Los Estados parte deben proveer los medios para el ejercicio de los derechos humanos y deben investigar, juzgar y sancionar las violaciones de derechos humanos.

Medina Ardila, F. (s.f) La Responsabilidad Internacional del Estado por actos de particulares: análisis jurisprudencial interamericano. (p.16). doi: r26724.pdf

Medina Ardila, F. (s.f) La Responsabilidad Internacional del Estado por actos de particulares: análisis jurisprudencial interamericano. (p.19). doi: http://www.corteidh.or.cr/tablas/r26724.pdf

Mendoza, L. (2014). La Acción Civil del Daño Moral. (pp. 51-52).235 Ed. México: UNAM.

Nash Rojas, C. (2009).Universidad de Chile: Facultad de Derecho. Las Reparaciones ante la Corte Interamericana de Derechos Humanos (1988-2007), segunda edición corregida y actualizada. [1-488]. Recuperado de http://www.corteidh.or.cr/tablas/r15428.pdf

Nash, C. (2007). Las Reparaciones ante la Corte Interamericana de Derechos Humanos. Recuperado de http://www.corteidh.or.cr/tablas/r15428.pdf

Nash, R. Alcance del Concepto de Tortura y Otros Tratos Crueles, Inhumanos y Degradantes. Anuario de derecho constitucional latinoamericano, versión (XV), (P.4), doi: r23545.pdf

Oficina del Alto Comisionado para la Paz. (s.f) ABC Medidas de Reparación Integral para la Construcción de Paz. Recuperado de http://www.altocomisionadoparalapaz.gov.co/Documents/informesespeciales/abc-del-proceso-de-paz/abc-medidas-reparacion-integral-paraconstruccion-paz.html

Oficina del Alto Comisionado para la Paz. (s.f) ABC Medidas de Reparación Integral para la Construcción de Paz. Recuperado de http://www.altocomisionadoparalapaz.gov.co/Documents/informesespeciales/abc-del-proceso-de-paz/abc-medidas-reparacion-integral-paraconstruccion-paz.html

Puhl, Stella M.1; Izcurdia, M. de los Ángeles2; Oteyza, Gabriela2; Gresia Maertens, Beatriz H. (2017). Peritaje Psicológico y Daño Psíquico. Facultad de psicología - uba / secretaría de investigaciones / anuario de investigaciones / 
volumen

xxiv.

[p.253].

doi:

http://ppct.caicyt.gov.ar/index.php/anuinv/article/download/11284/4545457575

8319

Relatora Especial Sra. Radhika Coomaraswamy (2002). Comisión de Derechos Humanos de las Naciones Unidas. Integración de los derechos humanos de la mujer y la perspectiva de género violencia contra la mujer. Periodo $58^{\circ}$ de sesiones. Recuperado de https://documents-ddsny.un.org/doc/UNDOC/GEN/G02/113/20/PDF/G0211320.pdf?OpenElement

Rutas del Conflicto. (s.f.). Masacre de Zabaletas 2000. Recuperado de http://rutasdelconflicto.com/interna.php?masacre $=175$

Unidad Investigativa El País, (30 de octubre de 2013). La sangrienta huella del exjefe paramilitar alias H.H. en el Valle del Cauca. El País. Recuperado de: https://www.elpais.com.co/elpais/judicial/noticias/sangrienta-huella-exjefe-

paramilitar-alias-hh-valle-cauca

Unidad Investigativa El País. (30 de octubre de 2013). La Sangrienta Huella del Ex jefe Paramilitar alias H.H en el Valle del Cauca. Diario El País. Recuperado de https://www.elpais.com.co/elpais/judicial/noticias/sangrienta-huella-exjefeparamilitar-alias-hh-valle-cauca

Unidad para la Atención y Reparación Integral a las Víctimas (UARIV). (s.f). Reparación Integral Individual. Recuperado de https://www.unidadvictimas.gov.co/es/reparacion-integral-individual/286

Unidad para la Atención y Reparación Integral a las Víctimas (UARIV). (s.f). DERECHO a la Reparación Integral a las víctimas del conflicto armado; preguntas frecuentas: Imprenta Nacional de Colombia.

Unidad para la Atención y Reparación Integral a las Víctimas (UARIV). (s.f). Ruta Integral Individual. Recuperado de http://www.unidadvictimas.gov.co/es/atencion-asistencia-y-reparacionintegral/ruta-integral-individual/11416

Velázquez, A (2017). Desplazamiento Interno por Violencia en México. Causas, Consecuencias y Responsabilidades del Estado. Comisión Nacional de Derechos Humanos, Primera edición. Recuperado de https://archivos.juridicas.unam.mx/www/bjv/libros/11/5197/9.pdf

Verdadabierta, (08 de agosto de 2018). Bloque Calima, un "depredador" paramilitar marcado por el narcotráfico. Verdadabierta. Recuperado de: https://verdadabierta.com/bloque-calima-depredador-paramilitar-marcadonarcotrafico/

Verdadabierta, (08 de agosto de 2018). Bloque Calima, un "depredador" paramilitar marcado por el narcotráfico. Verdadabierta. Recuperado de: 
https://verdadabierta.com/bloque-calima-depredador-paramilitar-marcadonarcotrafico/ VERDADABIERTA.COM. (2011). Rito Alejo Del Río y el Asesinato de Marino López. Recuperado de https://verdadabierta.com/rito-alejo-del-rio-y-elasesinato-de-marino-lopez/

\section{Normas Nacionales}

Código Penal Colombiano, Ley 599 de 2000. Artículo 137. Tortura en Persona Protegida.

Código Penal Colombiano, Ley 599 de 2000. Artículo 159. Desplazamiento Forzado de Población Civil. Deportación, expulsión, traslado o desplazamiento forzado de población civil.

Código Penal Colombiano, Ley 599 de 2000. Artículo 347.Amenazas.

Constitución Política de Colombia de 1991, artículo 12.

Constitución Política de Colombia de 1991. Artículo 11.El derecho a la vida es inviolable.

Corte Constitucional de Colombia. Sentencia T 045/95, p.6.

Corte Constitucional en las sentencias T-227 de 1997 y T-327 de 2001. Nociones del Desplazamiento del Interno.

Ley 387 de 1997. Medidas del Desplazamiento Forzado; la atención, protección, consolidación y estabilización socioeconómica de los desplazados internos por la violencia en la República de Colombia.

\section{Instrumentos Internacionales}

Asamblea General de la ONU, Principios y directrices básicos sobre el derecho de las víctimas de violaciones manifiestas de las normas internacionales de derechos humanos y de violaciones graves del derecho internacional humanitario a interponer recursos y obtener reparaciones. Resolución 60/147 del 16 de diciembre de 2005.

Asamblea General de las Naciones Unidas. Principios Rectores de los Desplazamientos Internos. Informe E/CN.4/1998/53/Add.2 del Representante del Secretario General, Sr. Francis M. Deng. 11 de febrero de 1998.

Asamblea General de las Naciones Unidas. Responsabilidad del Estado por Hechos Internacionalmente Ilícitos. Resolución No. 56/83 del 25/06/2010. 
Asamblea General, Principios y directrices básicos sobre el derecho de las víctimas de violaciones manifiestas de las normas internacionales de derechos humanos y de violaciones graves del derecho internacional humanitario a interponer recursos y obtener reparaciones. Resolución 60/147 del 16 de diciembre de 2005, Principio IX. Reparación de los Daños Sufridos.

Asamblea General. Convención contra la tortura y otros tratos o penas crueles del 10 de diciembre de 1984, articulo 1.

Convención Americana sobre Derechos Humanos, 1969, art.22 y 27.

Convención Interamericana para Prevenir y Sancionar la Tortura del 28 de febrero de 1987, articulo 2.

Convención sobre el Estatuto de los Refugiados. Adoptada en Ginebra, Suiza, el 28 de julio de 1951 por la Conferencia de Plenipotenciarios sobre el Estatuto de los Refugiados y de los Apátridas (Naciones Unidas), convocada por la Asamblea General en su resolución 429 (V), del 14 de diciembre de 1950.

Convenio Europeo de Derechos Humanos, articulo 3. Prohibición de la Tortura.

ONU, Principios rectores de los desplazamientos internos. Resolución de la Comisión de Derechos Humanos 11 de febrero de 1998.

Protocolo II Adicional a los Convenios de Ginebra de 1949 relativo a la protección de las víctimas de los conflictos armados sin carácter internacional de 1977, articulo 1.

\section{Jurisprudencia Nacional}

Corte Constitucional de Colombia. Sentencia C-344/17 del 24 de mayo de 2017.

Corte Constitucional, Sala Tercera de Revisión, T-719, 2003

Corte Suprema de Justicia, Sala de Casación Penal. Caso Cesar Pérez García, 15 de mayo de 2013.

Éver Veloza García, alias HH, septiembre 4 de 2008, sesión: 9.2008.09.04, ubicación: 9.2008.09.04, versionado: Éver Veloza (HH): Comandante Bloque Bananero y Bloque Calima de las ACCU Fiscal 17 Justicia y Paz Nubia Stella Chávez Niño).

Fiscalía de Ibagué, 730016099093201803156, 2018. 
Fiscalía de Ibagué, HMP-2018-00025570, 2018.

Fiscalía de Ibagué, TOLIM-GIT-No.2018140374012, 2018.

Fiscalía de Ibagué, TOLIM-GIT-No.2018140374012, 2018.

Juzgado Décimo Administrativo del Circuito Judicial de Ibagué, 73001-33-40010-2016-00123-00, 2016.

Juzgado Décimo Administrativo del Circuito Judicial de Ibagué, 73001-33-40010-2016-00123-00, 2016.

Juzgado Décimo Administrativo del Circuito Judicial de Ibagué, 73001-33-40010-2016-00123-00, 2016.

Unidad de Restitución de Tierras, DTTI1-201801306, 2018.

Versión Libre de Hebert Veloza, Alias H.H, ante la Fiscalía 17 de la Unidad de Justicia y Paz, (marzo 5 de 2008).

\section{Jurisprudencia Internacional}

(Corte Interamericana de Derechos Humanos, caso Baldeón García vs Perú, párr. 128, 2006); (Corte Interamericana de Derechos Humanos, caso Masacre de Mapiripam vs Colombia, supra párrs. 96.141, 96.145 y 96.175, 2006); (Corte Interamericana de Derechos Humanos, caso Lopez Alvarez vs Honduras, nota 6, párr. 119, 2006); (Corte Interamericana de Derechos Humanos, caso Gómez Palomino vs Perú, nota 1, párr. 144 y 146, 2005).

Corte Interamericana de Derechos Humanos. Caso 19 comerciantes vs Colombia. Sentencia 04 de julio de 2004. Párr. 149.

Corte Interamericana de Derechos Humanos. Caso Barrios Altos Vs. Perú .Sentencia de 14 de marzo de 2001 (Fondo) Párr.2.

Corte Interamericana de Derechos Humanos. Caso Bueno Alves vs Argentina. Fondo. Reparaciones y Costas. Sentencia del 11 de mayo de 2007, párr. 79.

Corte Interamericana de Derechos Humanos. Caso Campo Algodonero vs México. Sentencia de 16 de noviembre de 2009. (Excepción Preliminar, Fondo, Reparaciones y Costas). Párr. 412-420.

Corte Interamericana de Derechos Humanos. Caso Cantoral Benavidez vs Perú. Fondo. Sentencia del 18 de agosto de 2000, párr. 120.

Corte Interamericana de Derechos Humanos. Caso Castro Castro vs Perú. Fondo, Reparaciones y Costas. Sentencia del 25 de noviembre de 2006, párr.316. 
Corte Interamericana de Derechos Humanos. Caso Comunidades Afrodescendientes Desplazadas de la Cuenca del Rio Cacarica (Operación Génesis) vs Colombia. Excepciones Preliminares, Fondo, Reparaciones y Costas). Sentencia del 20 de Noviembre de 2013, Párr. 95.

Corte Interamericana de Derechos Humanos. Caso de Comunidades Afrodescendientes de la cuenca del río Cacarica (Operación Génesis) vs Colombia. Excepciones Preliminares, Fondo, Reparaciones y Costas. Sentencia del 20 de noviembre de 2013.Párr. 218.

Corte Interamericana de Derechos Humanos. Caso de las Comunidades Afrodescendientes Desplazadas de la Cuenca del Rio Cacarica vs Colombia. Excepciones Preliminares, Fondo, Reparaciones y Costas. Sentencia del 20 de noviembre de 2013, párr.92.

Corte Interamericana de Derechos Humanos. Caso de Los "Niños de la Calle" (Villagrán Morales y Otros) vs Guatemala. (Reparaciones y Costas). Sentencia del 26 de Mayo de 2001.Párr.84.

Corte Interamericana de Derechos Humanos. Caso de Los "Niños de la Calle" (Villagrán Morales y Otros) vs Guatemala. (Reparaciones y Costas). Sentencia del 26 de Mayo de 2001.Párr.8.

Corte Interamericana de Derechos Humanos. Caso Defensor de Derechos Humanos y Otros vs Guatemala. Excepciones Preliminares, Fondo, Reparaciones y Costas. Sentencia del 28 de agosto de 2014. Párr.78.

Corte Interamericana de Derechos Humanos. Caso Familia Barrios vs Venezuela. Fondo, Reparaciones y Costas. Sentencia del 24 de noviembre de 2011, párr.51.

Corte Interamericana de Derechos Humanos. Caso Fernández Ortega y Otros vs México. Fondo, Reparaciones y Costas. Sentencia del 30 de agosto de 2010, párr.124.

Corte Interamericana de Derechos Humanos. Caso Godínez Cruz vs Honduras. Sentencia de 21 de julio de 1989. (Reparaciones y Costas). Párr.26.

Corte Interamericana de Derechos Humanos. Caso Loayza Tamayo vs Perú. Fondo. Sentencia del 17 de septiembre de 1997. Párr. 57.

Corte Interamericana de Derechos Humanos. Caso Loayza Tamayo Vs. Perú Sentencia de 27 de noviembre de 1998 (Reparaciones y Costas). Párr.147.

Corte Interamericana de Derechos Humanos. Caso Mapiripán vs Colombia. Fondo. Reparaciones y Costas. Sentencia del 15 de septiembre de 2005- Serie C No. 4, párr. 113. 
Corte Interamericana de Derechos Humanos. Caso Maritza Urrutia vs Guatemala. Fondo, Reparaciones y Costas. Sentencia del 27 de noviembre de 2003, párr. 92.

Corte Interamericana de Derechos Humanos. Caso Masacre de Santo Domingo vs Colombia. Excepciones preliminares. Fondo y Reparaciones Sentencia del 30 de noviembre de 2012, párr.191.

Corte Interamericana de Derechos Humanos. Caso Masacres de El Mozote y lugares aledaños vs. El Salvador. Sentencia de 25 de octubre de 2012 (Fondo, Reparaciones y Costas) Párr.305. Y Corte Interamericana de Derechos Humanos. Caso Gomes Lund y Otros ("Guerrilha Do Araguaia”) vs. Brasil. Sentencia de 24 de noviembre de 2010 (Excepciones Preliminares, Fondo, Reparaciones y Costas). Párr.307.

Corte Interamericana de Derechos Humanos. Caso Masacres de El Mozote y lugares aledaños vs. El Salvador. Sentencia de 25 de octubre de 2012 (Fondo, Reparaciones y Costas) Párr.32.

Corte Interamericana de Derechos Humanos. Caso Niños de la calle (Villagrán Morales y Otros) vs Guatemala. Sentencia 19 de noviembre de 1999. Párr.165.

Corte Interamericana de Derechos Humanos. Caso Plan de Sánchez vs Guatemala. Fondo. Sentencia del 29 de abril de 2004, párr.42.7.

Corte Interamericana de Derechos Humanos. Caso Rosendo Cantú y Otra Vs. México. Sentencia de 31 de agosto de 2010. (Excepción Preliminar, Fondo, Reparaciones y Costas). Párr.128.

Corte Interamericana de Derechos Humanos. Caso Tibi vs Ecuador. Excepciones preliminares, fondo, reparaciones y costas. Sentencia del 07 de septiembre de 2004, párr. 146.

Corte Interamericana de Derechos Humanos. Caso Tibi vs Ecuador. Excepciones Preliminares, Fondo, Reparaciones y Costas. Sentencia del 07 de septiembre de 2004. Párr. 149.

Corte Interamericana de Derechos Humanos. Caso Valle Jaramillo vs Colombia. Fondo, Reparaciones y Costas. Sentencia del 27 de noviembre de 2008. Párr.108.

Corte Interamericana de Derechos Humanos. Caso Velásquez Rodríguez vs Honduras. Fondo. Sentencia del 29 de julio de 1988. Serie Con. 4, párr.134.

Corte Interamericana de Derechos Humanos. Caso Velásquez Rodríguez vs Honduras. Fondo. Sentencia del 29 de julio de 1988- Serie C No. 4, párr. 164, 169 y 170. 
Corte Interamericana de Derechos Humanos. Caso Yarce y Otros vs Colombia. Excepción Preliminar, Fondo, Reparaciones y Costas. Párr.127.

European Court of Human Rights. Caso Comingersoll, S.A. Contra Portugal. Sentencia 35382/97 del 06 de abril de 2000. Punto 2 artículo 41 del Convenio.

La corte interamericana de derechos humanos preciso este primer escenario en los casos hondureños de: Velásquez Rodríguez vs Honduras. Fondo. Sentencia del 29 de julio de 1988. Serie C No. 4, párr. 173; Caso Godínez Cruz vs Honduras. Fondo. Sentencia del 20 de enero de 1989. Serie C no. 5, párr. 183 y 187. Caso Fairén Garbi y Solís Corrales vs Honduras. Fondo. Sentencia del 15 de marzo de 1989. Serie C No. 6, párr. 152 y 161 .

\section{Bibliografía}

Galvis, L. (2012). Comprensión de los Derechos Humanos; Una Visión para el siglo XXI. Bogotá, Colombia: Ediciones Aurora.

Oficina del Alto Comisionado de las Naciones Unidas. (2012). Compilación de Instrumentos Internacionales. Bogotá, Colombia: ACDI.

Gallón, G., Orozco, I., Uprimny, R., Valencia, A. \& Valencia, H. (1991). Derechos Humanos y Conflicto Armado en Colombia. Bogotá, Colombia: Fundación Friedrich Naumann.

Escobedo, R. (2014). La Crisis de Buenaventura la Vive Todo el Pacífico. Recuperado de http://www.ideaspaz.org/publications/posts/983

FEDESARROLLO-CERAC. (2013). Hacia un Desarrollo Integral de la Ciudad de Buenaventura y su Área de Influencia. Recuperado de https://www.repository.fedesarrollo.org.co/bitstream/handle/11445/198/Hacia $\% 20$ un $\% 20$ desarrollo\%20integral\%20de\%20la\%20ciudad $\% 20 \mathrm{de} \% 20$ Buenave ntura $\% 20 \mathrm{y} \% 20 \mathrm{su} \% 20$ area $\% 20 \mathrm{de} \% 20$ influencia $\% 20$ -

$\% 20$ Informe $\% 20$ final $\% 202013$.pdf?sequence $=2$

Conselho Norueguês para Refugiados. (2014). Buenaventura, Colombia: Realidades Brutales. Recuperado de https://www.acnur.org/fileadmin/Documentos/Publicaciones/2014/9760.pdf

Cuastumal, J. (2013). Casos Colombianos Fallados por la Corte Interamericana de Derechos Humanos, Estudio a través de la Teoría del Derecho Procesal. Recuperado de https://aprendeenlinea.udea.edu.co/revistas/index.php/red/article/viewFile/200 $15 / 16901$ 
Universidad Externado de Colombia. (2015). Manual de Citación Normas APA. Recuperado de https://www.uexternado.edu.co/wpcontent/uploads/2017/07/Manual-de-citacio\%CC\%81n-APA-v7.pdf 
ANEXOS

ANEXO A. CONSENTIMIENTO

Anexo 1. Consentimiento informado del señor Luis Ángel Sinisterra Viveros.

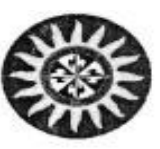

\author{
UNIVERSIDAD SANTO TOMAS \\ DIVISION DE CIENCIAS JURIDICAS Y POLITICAS \\ MAESTRIA EN DEFENSA DE LOS DERECHOS HUMANOS Y DEL DERECHO INTERNACIONAL \\ HUMANITARIO ANTE ORGANISMOS, TRIBUNALES Y CORTES INTERNACIONALES \\ BOGOTA D.C.
}

CONSENTIMIENTO INFORMADO PARA PARTICIPANTES DE INVESTIGACION

El presente documento tiene como objeto brindar información detallada a las personas que serán entrevistadas en el marco de la línea de investigación de crímenes internacionales y explicar los fines, la naturaleza de la misma su rol como participante y el uso y la difusión de la información obtenida.

La línea de investigación está orientada a la búsqueda y procesamiento de información sobre graves violaciones de derechos humanos a través de la sistematización de diversas fuentes, para dicha labor se realiza la construcción del texto teniendo como eje central el relato de la victima.

Las manifestaciones realizadas por la persona entrevistada serán utilizadas de manera estricta con fines académicos para la elaboración de la investigación bajo la observancia de la dignidad humana, el respeto y la voluntariedad. La información obtenida no será usada para ningún otro propósito distinto a la investigación. Adicionalmente, las manifestaciones realizadas por los entrevistados serán utilizadas para garantizar la centralidad de su relato en el proceso de investigación.

De acuerdo a lo anteriormente expuesto, yo, LoIS.ANGE2SINISTENAP VIVERO identificado con cédula de ciudadanía número $16 \% 26.950$ expedida en la ciudad de B, URP. TA225-2E2. CPSCA, autorizo al investigador, de forma consciente y voluntaria para que haga uso de la información obtenida en la entrevista con fines académicos. Así mismo, afirmo que han sido aclarados previamente todos mis interrogantes acerca del uso y difusión de la información en la investigación y los objetivos de la misma.

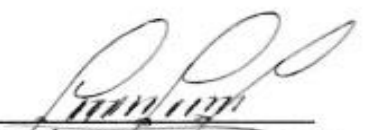

Luis Ángel Sinisterra Viveros Participante.

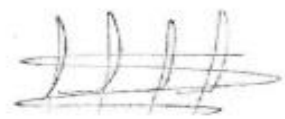

Dra Luisa Fernanda Trujillo $P$. Coordinadora de la Maestría.

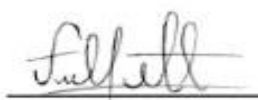

Edgar Felipe Millán Prada Estudiante Investigador.

Secud fodina Afy.

Dr David Medina Hernández Director línea de investigación. 


\section{Anexo 1.}

\section{ANEXO B. ENTREVISTAS}

Entrevista. Señor Luis Ángel Sinisterra Viveros. Realizada el 28 de marzo de 2017.

Fecha: 28 de marzo de 2017

\section{Ciudad: Ibagué, Tolima}

\section{Entrevistado: Sr. Luis Ángel Sinisterra Viveros.}

1. ¿Cuál es su nombre completo?

R: Luis Ángel Sinisterra Viveros.

2. ¿Cuál es su edad?

$R: 56$ años.

3. ¿Cuál es su estado civil?

R: Unión libre.

4. ¿Cuántos hijos tiene?

R: 7 hijos.

5. ¿Cuál es su domicilio?

R: Pues en estos momentos estoy aquí en Ibagué.

6. ¿A qué se dedica?

R: Yo me dedico a defender los derechos humanos de la población afro victimas del Tolima, soy representante de la mesa municipal de víctimas.

7. ¿Usted es víctima?

$R$ : Si soy víctima.

8. ¿Usted es víctima de qué hechos?

$R$ : Dos veces de desplazamiento forzado, amenazas y tortura.

9. ¿Quién lo detuvo?

R: Un grupo de paramilitares.

10. ¿Dónde lo detuvieron? 
R: Me detuvieron en el barrio Cristal.

11. ¿Cuándo lo detuvieron?

R: A mí me detuvieron entre el año 2010 y 2011 no me acuerdo bien por el trauma que uno tiene es muy grande, fue entre el mes de julio o mes de Agosto, en la mañana, eso me acuerdo que fue un día Sábado.

12. ¿Cuánto duró la detención?

R: Duro un día y medio.

13. ¿Qué le dijeron durante la detención?

R: Que nosotros éramos objetivo militar para ellos porque no estábamos de acuerdo con la función de que ellos estaba haciendo.

14. ¿Por qué cree que lo detuvieron?

R: Porque yo tenía un hijo mayor y ellos estaban buscando para incorporar gente para esos grupos y más que todo yo fui militar siempre le inculque a mi hijo que las cosas malas no se deben hacer mientras tanto ellos se sabían toda la hoja de vida mía... y porque yo no estaba de acuerdo llegaron y me dijeron "hermano necesitamos que colabore con la causa que su hijo sea parte de nosotros" yo dije que inunca que lo preferiría muerto...! Y también como yo siempre he trabajado como líder social de la población minoría, también pertenecí a un sindicato de Buenaventura de trabajo portuario SINTRAPUERTO, nosotros éramos muy visibles ante la demás gente entonces como no estábamos de acuerdo, el capitalista siempre busca a los defensores del trabajador para que esa persona no se defienda.

15. ¿Qué sucedió después?

R: Llegaron en un taxi amarillo me dicen súbase al carro que necesitamos hablar con usted, yo pensé que era una charla normal cuando ya me meten al sector de ellos, donde ellos mandan pues ya me decían que "vos sos el que no está de acuerdo con nosotros y ya van golpeando, pegando patadas, puños."

16. ¿Dónde lo golpearon?

R: En diferentes partes del cuerpo, en la barriga, en los glúteos, en las piernas. Eso fue entre 2010 o 2011, en el mes de agosto un día sábado.

17. ¿Cómo lo golpearon?

R: Me pegaron unas cachetadas como para que yo reaccionara pero yo nunca reaccione. 
18. ¿Quiénes lo golpearon?

R: Me golpearon los integrantes de ese comando paramilitar que operaban allá al mando de ese señor Tábano.

19. ¿Cuántos sujetos lo golpearon?

R: Eran como 15

20. ¿Cuánto duraron golpeándolo?

R: Media hora y luego cada 20 minutos me golpeaban.

21. ¿Estima que también sufrió otro tipo de tortura?

$R:$ Si, psicológicamente.

22. ¿Cuándo fue la tortura psicológica?

R: Después estando en mi casa

23. ¿Cómo fue la tortura psicológica?

R: Uno de ellos pasaba cada momento cerca de mi casa y yo pensaba en cualquier momento me puede matar y después uno de ellos llego y me dijo "sabes que la próxima vez te vamos a llevar a la casas de pique a desaparecerte por pedacitos y echarte a los tiburones".

24. ¿Cuál fue la duración de la tortura psicológica?

R: Unas semanas.

25. ¿Por qué cree que lo torturaron?

R: Por indiferencia, por yo no estar de acuerdo con ellos como soy defensor de derechos humanos no estoy de acuerdo con la violencia y con esos grupos al margen de la ley porque llegaron a los barrios a violar nuestras hijas, a violar las hijas de los vecinos, a mandar, los de las tiendas tenían que pagarles impuestos y tenían que darles de todo a vivir como un rey como si ellos fueran dueños de los barrios.

26. ¿Cómo fue su liberación?

R: No sé, como cosa de mi Dios porque mi Dios es muy grande y la Virgen llego un señor alias "Tábano" y dijo que me soltaran pero que tenía que abandonar ese barrio y Buenaventura. 
27. ¿Dónde fueron las amenazas?

R: En mi casa, allá donde me tenían y en el centro de Buenaventura cuando me los encontraba o pasaban a cada ratico.

28. ¿Cuándo fueron las amenazas?

R: Comenzaron en 2007 cuando me desplace hasta 2010 y luego en 2013 cuando volví a salir desplazado.

29. ¿Cómo fueron las amenazas?

R: Fueron personalmente, pasaban en un carro y me decían "hermanito póngase pilas que lo vamos a picar o se va de aquí”.

30. ¿Quién le hizo las amenazas?

$R:$ Los integrantes de los grupos al margen de la ley porque ahí operan Paramilitares, operaban en ese tiempo FARC, ELN, las Bacrim y La Empresa y todo eso.

31. ¿Porqué lo amenazaron?

R: Porque como yo soy defensor de los derechos humanos de la población étnica y era defensor del trabajador portuario de Buenaventura que es un trabajador que esta indefenso entonces el capitalista al ver que uno está haciendo un trabajo por la población se valen de estos grupos para intimidar a los colectivos, sindicatos, asociaciones y defensores de derechos humanos.

32. ¿Qué medio usaron para hacer las amenazas?

R: Me llegan cartas de Buenaventura diciendo que ya saben dónde estoy ubicado.

33. ¿Actualmente usted continua siendo amenazado?

R: Actualmente continúo siendo amenazado aquí en el Tolima ahoritica que soy más visible porque soy de la mesa de victimas departamental del Tolima.

34. ¿Cuándo se desplazó a Buenaventura, Valle?

R: Yo primero me desplace de Buenaventura en 2007 hasta 2010.

35. ¿Lo hizo solo o acompañado?

R: Si.

36. ¿Cómo se desplazó a Buenaventura?

R: Con mi familia. 
37. ¿Porqué se desplazó de Buenaventura?

R: Por la situación que vivía con mi familia, era muy pesado para mi familia.

38. ¿Quién lo obligó a tomar la decisión de abandonar Buenaventura?

R: Por las amenazas que estaba sufriendo.

39. ¿Cuándo se desplazó a Ibagué?

R: En 2007 y en 2013 volví nuevamente a Ibagué.

40. ¿Cómo fue su llegada a Ibagué?

R: No! Pues llegue normalmente, como ya conocía tenía varios amigos pero aquí prácticamente ha sido pasando las mismas necesidades, ha sido duro para la labor para las ayudas que da el gobierno para las víctimas y todo eso.

41. ¿En Ibagué donde se ubicó?

R: En un barrio marginado, un asentamiento llamado Milagro de Dios como decimos nosotros una invasión le hace falta todos los servicios públicos.

42. ¿continúo siendo víctima de algún delito en Ibagué?

R: Claro! yo sigo siendo víctima porque ahorita dentro de la mesa de víctimas sigo recibiendo amenazas.

43. ¿Cuándo es amenazado en Ibagué?

R: En Diciembre de 2016, estando en una finca avenida carrizales que queda en El Salado hacia afuera, llegaron dos tipos con traje negro y con pasamontañas y me amenazaron que tenía que irme de Ibagué y todo eso porque aquí nosotros los afro y los étnicos no tenemos derecho a nada ni a respirar. Que ellos no estaban de acuerdo con la paz.

44. ¿Cómo son esas amenazas en Ibagué?

$R$ : Personalmente y con panfletos.

45. ¿Quién hace las amenazas en Ibagué?

R: Se identificaron como miembros del ELN, también recibí amenazas por trabajar con la mesa de victimas del frente 21 de las FARC y por los Gaitanistas.

46. ¿Porqué lo amenazaron en Ibagué?

R: Porqué yo soy una persona visible y por donde voy yo voy defendiendo a la población minoría y a los afros. 
47. ¿Por qué intentó retornar a Buenaventura?

R: Por la situación que estaba viviendo yo con mi familia y las amenazas que recibí aquí en Ibagué.

48. ¿Cuándo intento retornar a Buenaventura?

R: En el 2011.

49. ¿Qué sucedió cuando intento retornar a Buenaventura?

R: Cuando llegamos allá a Buenaventura que ya estando ubicados, mi papa había dejado unas tierras en la vereda La Gloria cuando fuimos con mi hermano a reclamar eso, tuvimos la sorpresa que eso estaba invadido por un grupo que opera en estos momentos en Buenaventura Los Urabeños que son del golfo pues es un sector predilecto para ellos para sus cultivos y para sus negocios ilícitos a raíz de eso ellos fueron a la casa me amenazan y me dijeron que tenía que abandonar Buenaventura y fue entonces que volví en el 2013 a Ibagué por el desplazamiento y amenazas y ya hice la denuncia que reposa en la fiscalía de Buenaventura. 


\section{Anexo 2.}

Entrevista. Señor Luis Ángel Sinisterra Viveros. Realizada el 28 de agosto de 2018.

\section{Fecha: 28 de agosto de 2018}

\section{Ciudad: Ibagué Tolima.}

\section{Entrevistado: Sr Luis Ángel Sinisterra Viveros}

\section{Impactos}

1. ¿Características de los hechos vividos por usted, desde cuando empezó a sufrir estos hechos?

Desde los 43 años, el Estado sabe lo que pasa allá [Buenaventura], es un municipio que imposiblemente llegue la paz, por la misma situación, es un municipio rico en biodiversidad y de todo. Pero los recursos siempre salen para la capital, nunca queda para la población, entre más días más pobreza absoluta.

2. ¿Cuánto duró la tortura?

La tortura física duraron dos días y psicológica todo un tiempo.

¿Cómo eran ellos?

No, pues la mayoría era de la región y siempre los comandantes eran de afuera de Uraba, de Medellín.

3. ¿Cómo estaban vestidos?

No, pues ellos siempre usaban ropa de civil pero cuando ellos iban a hacer cualquier vaina se uniformaban como si fueran de la fuerza pública.

4. ¿Y usted los había visto antes?

Sí, yo los había visto antes, pero yo no había tenido ningún inconveniente con ellos. Hasta que comencé a ser visible por hacer la defensa de los derechos de la población portuaria, haciendo manifestaciones y desde ahí llego la intranquilidad para mí y para mi familia por estos señores.

5. ¿Cómo eran ellos físicamente?

Eran afro y como decimos nosotros "paisas de Medellín”.

6. ¿Quién era alias "Tabano”?

Era un pelado joven, de estatura mediana y medio trigueño. 
7. ¿Cómo se comunicaban ellos?

Siempre por celulares y el dialecto de ellos es dialecto de paisas, porque ellos venían de Uraba Antioquia y otros que estaban eran de ahí de Buenaventura. Muchachos que no tenían nada que hacer y se metían en esos grupos.

8. ¿Su proyecto de vida, familiar y social como lo describe ahora?

Duro, fracasado por completo porque la familia mía se desintegro, cada uno estamos por un lado y el proyecto de vida mío no sé hasta dónde voy a llegar, porque yo perdí una estabilidad que tenía de sostener a mi familia y sacarla adelante con el trabajo que yo estaba haciendo en mi región. Perdí mi identidad, perdí mi cultura, perdí tierra.

9. ¿Tiene desconfianza con los demás?

Claro, yo mantengo desconfiado con todo mundo por lo que sucedió y por lo que está sucediendo ahora contra los líderes y lideresas. Yo mantengo desconfiado con todos, hasta con los mismos compañeros que hacemos parte de las mesas de víctimas. Porque hay no se sabe quién es quién y puede haber gente infiltrada.

10. ¿Siente inhibido, se guarda cosas?

Sí, yo de vez en cuando me guardo cosas y no las expreso porque no se el impacto que vaya tener, entonces mejor me las guardo. Porque mi temperamento es un temperamento muy fuerte, entonces mejor me guardo las cosas.

11. ¿Se aísla socialmente?

Claro, yo de vez en cuando yo llego y me aislo me hago en un sitio solo. Me llegan momentos muy nostálgicos.

12. ¿Cómo cuales recuerdos nostálgicos le llegan a usted?

Añoro mucho mi ciudad, mi municipio donde está mi familia, mis amigos de la infancia, donde yo tenía mi trabajo, donde no pasaba necesidades como las estoy pasando ahoritica, volver a reunir a mi familia como la tenía antes y esos son muchos los recuerdos nostálgicos.

13. ¿Lo han juzgado?

Usted sabe que a uno no puede tener contento a todo mundo, así mismo en el colectivo, en la asociación que uno representa porque la gente nunca está contenta. Eso un $50 \%$ está contenta y un 50 \% está disconforme y lo juzga a uno sin cosa justificada porque no hay pruebas.

14. ¿Siente impotencia?

$\mathrm{Si}$, siento bastante impotencia cuando yo hago un reclamo, cuando yo le exijo a un secretario que porque no son cumplidos, su negligencia y la del Estado contra nosotros las víctimas. 
15. ¿Siente miedo?

De vez en cuando me da miedo.

¿Siente inseguridad?

Inseguridad si se siente, bastante claro. En el momento que uno se levanta de la cama se siente inseguro.

16. ¿Siente pesadillas?

Pesadillas pues sí.

17. ¿Siente tensión o estrés?

Bastante se siente uno tensionado y estresado porque cuando llega un día de que usted no puede salir a una diligencia por el factor dinero, por el factor de amistad, factor de comunicación y se encuentra usted en una tierra ajena donde su cultura no prevalece, está olvidada acá.

18. ¿Ha tenido conflictos familiares?

Si, con los hijos ya grandes porque a raíz del desplazamiento hemos tenido conflictos porque perdimos la casa, hemos perdido cosas y entonces los hijos mantienen reprochando eso. Pero como dice la cosa, eso no está en manos mías sino cuestión del Estado que no lo protegió.

19. ¿Hubo desintegración familiar?

Sí, claro y está bastante dura.

20. ¿Ha tenido problemas económicos?

Nosotros como víctimas del conflicto es este el problema más duro que hay, el económico.

21. ¿Qué piensa de la respuesta del Estado?

Mala! Mala el Estado no ha hecho nada por eso la Corte declaró inconstitucionalmente la protección contra la población étnica como afros e indígenas en el auto 266 de agosto de 2017, el Estado ha nosotros no nos ha protegido nada ni ha resarcido los derechos que perdimos.

22. ¿Qué ha hecho el Estado por su familia?

Nada, ni a mí ni a mi familia.

23. ¿Ha buscado servicios de salud?

Hermano ya llevo como 7 años que no tengo servicio de salud. 
24. ¿Tiene problemas de salud?

Claro, yo soy hipertenso y el Estado no ha hecho nada.

25. ¿Tiene problemas psicológicos?

Problemas psicológicos no, lo único que me molesta es como el estrés, pero yo me prepare muy bien como líder. El estrés si me molesta por la situación monetaria y porque estoy en una tierra ajena porque si estuviera en mi departamento no tendría problemas, porque uno sabe cómo moverse allá.

26. ¿Tiene angustia?

Sí, me angustio cuando las cosas no se dan. Me angustio cuando van pasando los años y meses, y las cosas no mejoran, no se solucionan. Porque entre más días más peor vamos nosotros. De ver las victimas salir del problema que tienen y como que las están hundiendo más. Porque la vaina de victimas es como una caja menor para el Gobierno, las victimas las tienen no más de figuras, nada más.

27. ¿Tiene barreras que le impiden expresar sus emociones?

He encontrado bastantes barreras porque varías veces gente cuando uno se expresa, opinan de nosotros sin conocer nuestra cultura.

28. ¿Se ha sentido estigmatizado?

En el mismo colectivo que uno hace parte como son las mesas municipales, departamentales y nacionales.

29. ¿Siente infelicidad?

En este momento estoy bastante infeliz porque no estoy reunido con mis hijos, con mis familiares. En este momento estoy solo, entonces es una infelicidad, soy una persona sola.

30. ¿Hay desesperanza?

Sí, hay desesperanza es que yo me pongo a analizar la situación y yo no veo por donde se van a solucionar los problemas. Es que no lo veo, porque entre más días pasan es peor, porque Gobierno viene Gobierno pasa y no hay un proyecto de solución para las víctimas no hay. 


\section{Afrontamiento}

1. ¿Que hizo usted para enfrentar lo sucedido?

No, pues la valentía y mis conocimientos me toco para enfrentarlo. Del mismo miedo me dio valentía para enfrentar todos los hechos.

2. ¿Tuvo afrontamiento religioso?

Claro es que primero que todo, sea lo que me sucedió o no me hubiera sucedido yo siempre me encomiendo al Señor.

3. ¿Sintió aislamiento?

Si bastante, hemos sentido bastante aislamiento.

4. ¿Busco información?

Si yo busco bastante información, yo soy un tipo que me mantengo buscando esa información, me gusta leer, tener mucho conocimiento para cuando yo voy a hacer un reclamo yo tenga base y sustento con algo.

5. ¿Ha intentado o ha reconstruido los lazos afectivos y familiares?

Sí, claro, he yo intentado, en estos momenticos ya tenemos una comunicación porque antes no teníamos una comunicación con los hijos grandes yo cuando puedo pues yo viajo a visitarlos y entonces yo trato como de unirlos de nuevo.

6. ¿Es Usted líder porque siente el compromiso con la comunidad, con su familia y con sus amigos?

Yo desde muy joven me sentí representado en reclamar los derechos de las personas indefensas, de representarlas, es que yo viendo en el transcurso de mi juventud yo veía que había personas que no sabía reclamar y no sabía dónde ir y yo me daba la idea de eso de acompañarlos, de ayudarlos y ser líder nació conmigo.

7. ¿Tiene compromiso político?

Hago política en la defensa de los derechos humanos del pueblo afro y yo sé que eso es un compromiso.

8. ¿Le gusta hablar de lo ocurrido?

No me gusta mucho hablar de eso.

9. ¿Oculta sentimientos? 
Si oculto sentimientos porque no sé cómo lo va tomar la persona o de burlarse de uno porque hay personas que son felices con el dolor de otros.

\section{0. ¿Ha buscado apoyo psicosocial?}

Sí, me hicieron un programa que hace el gobierno pero eso no más es por encimita, eso queda en las nubes porque el funcionario que manda al psicólogo quieren que le cuenten todo lo que sucedió y nunca le da una solución solamente es como cumplir un contrato y listo.

\section{1. ¿Se ha organizado con grupos?}

Si ahoritica estamos más integrados, ahorita yo hago parte de un espacio nacional, soy presidente y representante legal de la asociación ASFROVICTOL, la cual nació en el departamento del Tolima y en la ciudad de Ibagué porque cuando llegué como víctima del conflicto aquí a Ibagué me encontré que muchos afros estaban en los semáforos y en las calles pidiendo. Y cuando iban a reclamar sus derechos pues no sabían entonces me di en la tarea de recogerlos, los organizamos para reclamar nuestro derecho como colectivo que tiene que ver el Municipio y el Departamento en cuestión de grupos étnicos victimas porque nosotros tenemos unos decretos ley como el 2635, que es el que nos rige a nosotros y acá en este Departamento no está cumpliendo. Entonces desde ahí nació la asociación ASFROVICTOL.

\section{2. ¿Usted ha crecido a raíz de lo que sucedió?}

Sí, eso tiene sus cosas buenas y sus cosas malas. Cosas buenas he crecido me he dado a conocer a nivel nacional, por las redes, me conocen más valorizan mi trabajo me han dicho que gracias a la función mía en el Tolima ya los afros estamos saliendo adelante, se les reconocen cosas. Claro que no está del todo bien, porque todavía hay falencias pero si hay un crecimiento hay más crecimiento que cosas malas. Cosas malas que trajo esto, como la discriminación, la estimación, la violación de nuestros derechos por desconocimiento de los funcionarios. Porque los funcionarios piensan que la raza indígena y la raza afro no existen por el desconocimiento. Pasaron por unas universidades, por planteles educativos pero nunca les hablaron de eso porque como hace falta la catedra étnica en los planteles para que los muchachos desde la primaria vayan sabiendo cual es la población étnica y cuáles son los derechos y todo. 


\section{Anexo 3.}

Entrevista. Señor Luis Ángel Sinisterra Viveros. Realizada el 28 de diciembre de 2018.

\section{Fecha: 28 de diciembre de 2018}

\section{Ciudad: Ibagué, Tolima}

\section{Entrevistado: Luis Ángel Sinisterra Viveros}

1. ¿Cuándo empezó a denunciar los hechos?

Desde 2003, todo el mundo sabía (...) en el 2003 se pudo en conocimiento ante el personero y el personero me dijo no eso es muy peligroso se va tener que ir y yo le dije yo no me voy todavía (...).

2. ¿Qué sucedió después?

En el año 2013 hice la reclamación de la tierra que me dejo mi padre porque estaba ocupada por los paramilitares.

3. ¿Qué medidas le ha brindado el Estado?

En el departamento del Tolima todavía desconoce lo que es grupo étnico, por eso es que aquí el gobierno no ha hecho una rehabilitación pa' nosotros los grupos étnicos. Ellos [Estado] lo hacen general. La ley dice que a nosotros como étnicos hay que hacerlo muy aparte con sus costumbres y eso hay que buscar la consultiva, si el gobierno va hacer un programa primero tiene que venir a consultar con la comunidad "señores les sirve o no les sirve", entonces la comunidad de nosotros ponemos las condiciones. Ese programa tiene que hacerlo una misma persona de nuestra comunidad porque él es quien conoce nuestra costumbre. En cambio aquí en el departamento hicieron un programa de psicología que se llama PAPSIVI, pero fue en general a todas las víctimas, con un profesional de ellos [Estado]. Si hay veinte afros debe haber un profesional afro, que es él que sabe. Es que no lo han hecho ni en Bogotá.

4. ¿En la medida de rehabilitación que le ha brindado el Estado?

Eso lo prestan en general pero no especial.

5. ¿Con respecto a la indemnización que se le ha prestado?

La indemnización todavía no ha llegado, nosotros la estamos solicitando como grupo étnico. La indemnización la han hecho en general (...) ahoritica 
habían sacado una resolución la 1958 donde venía "prioridad a la persona de la tercera edad que tenga 74 , persona con cáncer, pero nunca pusieron personas especiales étnicas, nada! Entonces nosotros la demandamos. Es que lo que pasa es que el gobierno y la Unidad de Víctimas sacaron la ley 1448 y sacaron los decretos ley 4633 de 2011 que son de nuestra población pero ellos [Estado] siempre aplican la 1448.

6. ¿Qué ha pasado con su proyecto de vida?

El Tolima se ha quedado en eso ni la administración municipal ni departamental desconocen. Mi proyecto de vida está estancado claro! Porque para yo tener un proyecto de vida tienen que darme uno productivo, el Estado tiene que devolverme lo que yo tenía para yo hacer mi vida.

7. ¿Qué le ha brindado el Estado respecto a la medida de restitución?

Cuando hacen la restitución, esa restitución va con un proyecto productivo de vida pero lo que sucede es que el departamento de Valle que recién iba a focalizar pero como se volvió otra vez violento pues usted sabe cómo es eso. Aquí en el municipio no hay establecido una ruta de reubicación si de retorno, y yo no me quiero quedar aquí.

8. ¿Con las medidas de satisfacción que ha sucedido en su caso?

Ahora es eso que hacen de la memoria histórica, para mí eso no es una medida para mi es que la víctima vuelva al estado en que ella estaba antes del conflicto esas si son medidas. En mi caso sería que se devuelvan las tierras de mi papa, mi casa, que yo vuelva a mi tierra [Buenaventura] y que yo vuelva hacer mi labor que yo hacía pero allá. Porque si yo me quedo por acá [Ibagué] deban ponerme un proyecto productivo, un proyecto de vida que yo pueda generar mi ingreso.

9. ¿Ante las Garantías de no repetición que le ha respondido el Estado?

En Buenaventura, el gobierno tiene que llevar obras sociales, no llevar ejercito llevar fuente de trabajo, llevar empresas. El Estado piensa que con llevar el ejército ya con eso va solucionar los problemas en Buenaventura. Los problemas en Buenaventura son sociales. Que la gente tenga como generar su ingreso diario pero sino pues viene un grupo armado y los adsorbe les dicen "ustedes se van a ganar esto y ya listo". Allá deben es traer empresas que generen empleo y que le den trabajo a la gente de ahí y no llevarlos del interior porque eso es lo que hacen. Que sacan con capacitarlos porque hay mucha gente capacitada allá (tecnólogos, técnicos, profesionales) pero están con el título en la casa, porque no hay las vacantes, porque son para la gente de afuera. La memoria histórica no sirve, eso es para gastar un poco de plata. 


\section{Anexo 4.}

Entrevista .Señor Juan*. Realizada el 14 de noviembre de 2018.

Fecha: 14 de Noviembre de 2018

Ciudad: Ibagué, Tolima

Entrevistado: Sr. Carlos Cabezas (Amigo de Luis Ángel Sinisterra Viveros)

1. ¿Cuál es su nombre completo? CARLOS CABEZAS GONZALEZ (Juan)* Para proteger su identidad.

2. ¿Cuál es su edad?

39 Años

3. ¿Cuál es su domicilio?

En el momento vivo en Ibagué soy desplazado también de Buenaventura, Valle del Cauca.

4. ¿A qué se dedica?

Soy tapicero, trabajo la ebanistería y la tapicería.

5. ¿Conoce al señor Luis Ángel Sinisterra Viveros?

Si, de Buenaventura, somos paisanos

6. ¿Qué parentesco tiene usted con el señor Ángel Sinisterra?

No, amistad.

7. ¿Hace cuánto tiempo que conoce a Don Ángel?

Maso menos de 15 a 20 años

8. ¿Cómo conoció a Don Ángel?

Allá en Buenaventura 
9. ¿Narre cómo era la situación de orden público donde ustedes vivían?

Allá él trabajaba y yo era comerciante. Que pasa, de pronto para la gente del interior hablándolo así, desconocen la situación. Que pasa allá, todo comerciante tiene que pagar, persona tiene que pagar por su seguridad. Si Usted no paga le pasa algo, así de sencillo a Usted o a su familia. Ahí había paras, guerrilla es decir de identificarlos ellos no tenían brazaletes no tenían nada sino que llegaban " $y$ bueno o paga o paga" hay Usted no puede decir fue fulano porque para preguntarle venga usted de donde es eso si no son fuerza pública para uno identificarlos en Buenaventura.

Eso toda la vida ha existido desde que yo tengo uso de razón. Que ahora se está dando a conocer es una cosa pero eso toda la vida ha existido.

10. ¿Tiene usted conocimiento de las razones por las cuales el señor Ángel fue víctima? Claro él fue secuestrado, sino estoy mal por un grupo paramilitar.

11. ¿De qué hechos fue víctima Don Ángel?

Diría yo que fue torturado porque al secuestrarlo desde ahí comienza los problemas psicológicos, tortura. Él vivía en el barrio El Cristal. Que pasa, como yo era comerciante yo tenía un negocio y era jefe de seguridad de cinco negocios más. Y eso pa' nadie es un secreto que todo comerciante tiene que pagar, personas que tengan un trabajo pagan y el que no paga... Gracias a Dios no paso a mayores con mi compañero [Don Ángel] pero por lo general si se ha dado cuenta de las noticias mire todo lo que pasa.

12. ¿Quién lo torturó?

Los Paramilitares, eso sí fue un grupo que él me conto que fue de los paramilitares pero que ya estaban ahí, como le digo yo cuando son esos sucesos se identifican así.

13. ¿Qué consecuencias tuvo en usted?

Por un amigo uno siente dolor, pero eso es el pan de cada día allá eso es normal. Si puede ver las noticias se da cuenta de lo que sale y aparece o sea las noticias no dicen todo lo que es, ahí se puede dar cuenta.

Después de él [Don Ángel] lo viví yo. Después que paso eso, yo me quede, yo tenía un negocio yo lo perdí. Tenía villarines y videojuegos estaba registrado en cámara de comercio. Lo perdí porque yo trabajaba con un primo... a mi primo lo 
secuestraron y lo mataron y de ahí quien seguía [Se señaló así mismo] o me abría y me desplace también por los paramilitares.

14. ¿Por qué cree que torturaron al señor Ángel?

No sé, no recuerdo bien si fue por no pagar o por algo no lo tengo muy claro, creería yo que fue por no pagar, por reusarse a pagar la "vacuna" lo que se llama la vacuna.

15. ¿Qué sucedió después?

Él creo que perdió el trabajo y tuvo que desplazarse.

16. ¿Quién hizo las amenazas?

Claro antes creería yo que antes de secuestrarlo y torturarlo primero fueron las amenazas, es que primero son como un preaviso por decirlo así. A veces le dan el preaviso o a veces de una vez y eso no tiene consistencia.

17. ¿Cuándo fueron las amenazas?

Allá [Buenaventura] las amenazas son "usted tiene un negocio o Usted trabaja tiene que dar tanto, esa es la cuota, venimos tal día por ella no más, sino aténgase no más."

18. ¿Por qué cree que amenazaron a Don Ángel?

Contra todos, contra todo el que no pague, eso no es solo contra el compañero [Don Ángel] o contra mí. Eso es contra el que no pague.

19. ¿Qué opinión tiene usted sobre los hechos (amenazas, torturas)?

Mire la situación es la siguiente allá [Buenaventura], allá hasta que no solucionen el problema de pobreza, el problema de trabajo y como eso es puerto pasan droga, armamento, entra plata, hay no hay nada que hacer. Eso no lo solucionan con pañitos de agua tibia.

20. ¿Qué solución cree usted que se puede dar en Buenaventura?

Mire la solución han creído que es meter más fuerza pública, meter tanquetas a patrullar porque en Buenaventura patrullan con tanquetas blindadas y eso no ha servido como puede ver hoy que paso mire las noticias y vera como 11 muertos hoy, ayer que paso? No eso no, todos los días son muertos.

21. ¿Tiene la esperanza de volver? 
No, me gustaría pero yo soy consciente, soy objetivo militar o sea si yo no me quiero me voy pero yo me quiero y tengo familia entonces no puedo. Que vaya yo de entrada y salida puedo, pero de ir a quedarme eso es una locura. Eso es una mentira eso no se puede volver para radicarme no de paso sí.

22. ¿Cómo es su situación ahora en Ibagué?

Por el momento por decir de 1 a 10, es 5. Porque trabajo para un almacén le fabrico a él. Pero por parte de la UAO de la unidad de víctimas, no hay ayudas no hay nada.

23. ¿Qué ha hecho el Estado?

No ha hecho nada, una ayuda no la dan cada año o sea cada año comemos imagínese.

24. ¿Cuál sería su opinión del Estado?

De mala en peor, porque como es que para los paras hubo una cosas, pa' la guerrilla hubo cosas y pa' nosotros que fuimos las víctimas que ha pasado? Ahí está.

25. ¿Cuál es la situación desde su punto de vista de Don Ángel en Ibagué?

Aquí [Ibagué] no solo él más de uno estamos bien en cuanto el problema de que nos van a matar hasta el momento pero trabajo para nosotros o ayudas para nosotros no hay y si gustan pueden revisar cada cuanto recibimos una ayuda del gobierno y ahí se dan cuenta si hablamos mentiras o hablamos la verdad.

26. ¿Qué le gustaría que hiciera el Estado?

Que cumpliera lo que está por ley y por decreto "que cada 4 meses las ayudas". Que cumplieran lo que está estipulado y eso no lo cumplen, en el año nos deberían de dar 3 ayudas y nos dan si acaso una, nos deberían de dar proyectos productivos, nos deberían ayudar para la vivienda aquí en Ibagué no hay proyectos de vivienda no hay nada, entonces que cumplan lo que está escrito no es lo que yo pida sino lo que está ahí eso es lo que yo pido que cumplan lo que está. No somos 2 o 3 somos miles de desplazados. 


\section{ANEXO C. AUDIOS}

\section{Anexo 1.}

Audio. Señor Ángel, 28 de marzo de 2017.

\section{Anexo 2.}

Audio. Señor Ángel, 28 de agosto de 2018.

Anexo 3.

Audio. Señor Juan*, 14 de noviembre de 2018.

\section{Anexo 4.}

Audio. Señor Ángel, 28 de diciembre de 2018. 